РОССИЙСКАЯ АКАДЕМИЯ НАУК ИНСТИТУТ АРХЕОЛОГИИ

О.А. Гей, Э.А. Сымонович

Позднескифский могильник КРАСНЫЙ МАЯК (раскопки 1976-77 гг.)

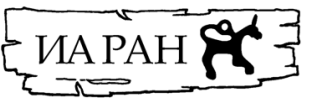

Москва, 2019 
Утверждено к печати Ученым советом ИА РАН

Ответственный редактор доктор исторических наук А.М. Обломский

Рецензенты:

доктор исторических наук О.В. Шаров

И.О. Гавритухин

Гей О.А., Сымонович Э.А. Позднескифский могильник Красный Маяк (раскопки 1976-77 гг.). - М.: ИА РАН, 2019. - 84 с.: ил.

В монографии публикуются материалы археологических исследований на позднескифском некрополе в с. Красный Маяк на Нижнем Днепре (Херсонская обл., Украина), которые проводились Черняховской экспедицией ИА АН СССР под руководством Э.А. Сымоновича в 1976-77 гг. Книга предназначена для археологов, историков, этнографов, работников музеев, студентов исторических факультетов и краеведов.

In the monograph the materials from the late Scythian burial ground Krasny Mayak in Kherson region, excavated by Chernyahovskaya archaeological expedition of the Academy of Science of the USSR in 1976-77 are published.

For archaeologists, historians, ethnographers, students of historical departments.

ISBN 978-5-94375-293-3

DOI: 10.25681/IARAS.2019.978-5-94375-293-3

(C) О.А. Гей, 2019

(C) Федеральное государственное бюджетное учреждение науки Институт археологии Российской академии наук, 2019 


\section{Введение}

Некрополь у Бизюкова монастыря (ныне с. Красный Маяк Бериславского района Херсонской обл., Украина), как и соответствующее ему городище, принадлежит к группе памятников Северного Причерноморья, которые после исследований Б.Н. Гракова и М.И. Артамонова (Граков, 1954; Артамонов, 1948), как правило, относят к позднескифской культуре (табл. 1). В диссертации Н.Г. Елагиной территория Нижнего Поднепровья рассматривается как северная окраина Малой Скифии Страбона, менее развитая и эллинизированная, чем Крым (Елагина, 1953. С. 53). Примерно к таким же выводам приходят другие исследователи (Шульц, 1971. С. 139; Дашевская, 1989. С. 140).

Первые суммарные описания нижнеднепровских городищ были составлены еще в конце XIX в. (Чирков, 1867; Ястребов, 1894), затем разведки проводились В.И. Гошкевичем (Гошкевич, 1913). Стационарные раскопки разного масштаба предпринимались на некоторых городищах - Белозерском, Николаевском (Казацком), Любиловском, Знаменском, Гавриловском, Золотобалковском, Анновском, Большая Ленетиха (Гошкевич, 1913; Ebert, 1913; Погребова, 1958; Вязьмитина, 1986; Симоненко, Сікоза, Дзнеладзе, 2015. С. 5, 6).

Погребальные памятники, которые, предположительно, соответствуют городищам, довольно разнообразны. Н.Н. Погребова высказала предположение о том, что на раннем этапе существования городищ знать предпочитала хоронить умерших под курганами (Погребова, 1958. С. 203). Несомненно, аристократическим было и погребение с золотыми лицевыми пластинами в валу Знаменского городища (Погребова, 1958. С. 128). На Нижнем Днепре изучены также рядовые, бескурганные могильники. К ним относится и некрополь у бывшего Бизюкова монастыря. Кроме того, раскопки проводили в Николаевке - Казацком) (Ebert, 1913; Сымонович, 1969) и Золотой Балке (Вязьмитина, 1972).

По вопросу о происхождении позднескифской культуры Нижнего Поднепровья не существует единой точки зрения. Наиболее обоснованным представляется предположение А.В. Симоненко о миграции населения из области распространения "тираспольских курганов" (Симоненко, Сікоза, Дзнеладзе, 2015. С. 6-9; Симоненко, 2016).

Попытки выстроить хронологическую последовательность памятников Нижнего Поднепровья на рубеже эр, отражающую взаимоотношения различных групп населения, обнаруживали больше вопросов, чем ответов. Так, Э.А. Сымонович полагал, что в этот регион черняховское население проникает уже во II веке н.э. и в дальнейшем мирно сосуществует с "поздними скифами", воспринимая отдельные элементы их культуры, в частности традицию захоронения умерших в склепах-катакомбах. Тесное взаимодействие между группами позднескифского и черняховского населения подтверждается, по мнению Э.А. Сымоновича, фактами погребения на одном и том же кладбище у с. Красный Маяк и Николаевка представителей различных племен (Сымонович, 1971. С. 65-74).

Однако в дальнейшем раскопки некрополя у с. Красный Маяк выявили позднескифские материалы II в. н.э. без каких-либо следов влияния черняховской культуры. Это несколько нарушало стройность нарисованной картины.

М.Б. Щукин обнаружил в материалах Николаевского могильника большой хронологический разрыв - одна группа погребений принадлежала к I - началу II, а другая к середине III IV в. н.э. В это же время находки из с. Красный Маяк представляют почти непрерывную линию развития от I до III - IV вв. н.э. (Щукин, 1970. С. 61; 1979. С. 71-74). Эти наблюдения позволили говорить о бурных событиях, происходивших в Нижнем Поднепровье во II - III вв. н.э. и нарушавших стабильность культуры. В конце этого периода, по мнению М.Б. Щукина, в северной 
части этой территории появилась черняховская культура, а в южной - формируется сходная с ней "киселовская" (Щукин, 1979. С. 72). Сосредоточенность автора лишь на вопросах хронологии обусловила искусственность выделения "киселовской культуры". Детальное изучение погребального обряда показало, что катакомбы позднескифского периода в Нижнем Поднепровье (I - начала III в. н.э.) всегда имеют в плане Т-образную форму, тогда как у катакомб более позднего времени входная яма и камера вытянуты по одной оси. Разница эта в данном случае носит принципиальный характер. Хронологический разрыв в материалах Николаевки получает простое и логическое объяснение: эти группы принадлежат двум различным культурам - позднескифской и черняховской. В черняховской культуре катакомбы и подбойные могилы относятся, скорее всего, к числу сарматских элементов (Гей, 1987. С. 66; 1993. С. 164, 165).

Определение четкого хронологического рубежа - вторая треть III в. н.э. - между двумя группами памятников Нижнего Поднепровья внесло ясность по многим вопросам. Однако единая хронологическая шкала первых веков н.э. для этого региона еще не разработана. Большое значение для решения этой задачи имеет материал некрополя у Бизюкова монастыря (с. Красный Маяк), который непрерывно функционировал на протяжении, по крайней мере, двух с половиной столетий.

Городище расположено на берегу Днепра (ныне Каховское море), у устья глубокой балки, которую В.И. Гошкевич называет "Пропастной". Первые погребения были обнаружены при земельных работах в монастырской усадьбе, по другую сторону балки (табл. 2). Упоминаются человеческие скелеты, обставленные горшками, при одном из них найден кубок из толстого зеленого стекла, украшенный зигзагообразной стеклянной нитью (Гошкевич, 1913. С. 135, рис. 36); не исключено, что эти погребения могут относиться к черняховской культуре. Большой некрополь был обнаружен также к югу от монастырской усадьбы, на высоком берегу Днепра, примерно в версте от городища. Монахи раскопали 136 могил без насыпи. Об обряде погребения сохранилось мало сведений, В.И. Гошкевич упоминает лишь, что "скелеты лежали попарно" (Гошкевич, 1913. С. 135). Немногочисленные вещи были направлены в Херсонский музей. Интересны некоторые находки: фибулы - бронзовая двупластинчатая и северопричерноморские сильно профилированные, костяной гребень с полукруглым выступом на спинке, костяная пирамидальная подвеска, бронзовое зеркало с центральной петлей и зеркала-подвески. Характер находок смешанный: погребения могли относиться как к позднескифской, так и к черняховской культурам.

В 1975 г. поступило сообщение об обнаружении еще одного могильника при строительстве новой части поселка, отделенной от монастыря глубокой балкой и расположенной к северо-западу от городища (табл. 2). Ряд домов вдоль улицы Пушкина обращен фасадами к городищу и Каховскому морю. Здесь Э.А. Сымоновичем в 1976 г. были заложены с помощью бульдозера (табл. 5, II) первые три траншеи (ширина 4 м, длина - соответственно 42, 41, 22 м). Последняя, третья, траншея находок не дала. Кроме того, было заложено два шурфа. В первом, небольшого размера (4 х 4 м), не оказалось следов захоронений. Во втором (10 х 2 м) находилась могила 1. Проводились также исследования "кургана, насыпанного из камней", расположенного в роще между ул. Пушкина и городищем (табл. 3, 6, I, III). В целом вскрытая площадь на могильнике в 1976 г. составила около 500 кв.м (Сымонович, 1976. С. 3).

В 1977 г. вдоль ул. Пушкина были прорыты две канализационные траншеи, и в дальнейшем на территории могильника построены очистные сооружения (табл. 2; 5, II). Эти земляные работы привели к разрушению множества могил, лишь часть вещей из них поступила в музей при местной средней школе. В 1977 г. Черняховская экспедиция под руководством Э.А. Сымоновича продолжила исследования в с. Красный Маяк. В местах, где траншеями канализации было разрушено наибольшее число могил, заложен раскоп I (площадь 335 кв.м; табл. 3;4;19, II). Кроме того, для доследования задетых водоводом погребальных сооружений в 350 м к востоку от раскопа I были заложены 3 шурфа общей площадью 28 кв.м и несколько южнее - еще один (6 х 6 м). К сожалению, на общем плане всех работ 1976-77 гг. эти шурфы отсутствуют, 
поэтому их местоположение установлено лишь предположительно (Сымонович, 1977. С. 5, 31; табл. 4). Всего Черняховской экспедицией за два сезона вскрыта 41 могила (Сымонович, Гей, 1978).

Характер напластований на территории, занятой могильником, был везде примерно одинаков. Под дерновым покровом мощностью 0,20-0,30 м шел серый, довольно сильно гумусированный суглинок, достигавший глубины 0,6-0,8 м. Материк представлял собой суглинок желтоватого цвета, на котором не вполне отчетливо прослеживались светло-серые пятна древних перекопов. В некоторых местах на территории могильника верхние слои были нарушены современными земляными работами и смывами.

Находки из раскопок 1976-77 гг., которые удалось обнаружить в ИА РАН, были отреставрированы и переданы О.А. Гей в ГИМ, после чего заново нарисованы художником А.В. Журавлевым.

При описании могил, раскопанных в 1976-77 гг., использовались полевые отчеты Э.А. Сымоновича (Сымонович, 1976, 1977), а также материалы из домашнего архива, любезно предоставленные вдовой Э.А. Сымоновича, О.Н. Мельниковской. К сожалению, Э.А. Сымонович составлял таблицы к отчетам не по комплексам погребений, а по категориям инвентаря. Некоторые находки, в частности бусы, вообще не фигурируют ни на таблицах, ни в описаниях. Это сильно затруднило работу по публикации материала некрополя у с. Красный Маяк. Все таблицы в издании составлены О.А. Гей, текст описаний могил полностью переработан.

Приношу также благодарность А.В. Симоненко и Д.М. Сикозе за предоставление картографических материалов (табл. 1, 4). Предположительное местонахождение шурфов 3-6 показано О.А. Гей. 


\section{Раскопки 1976 г.}

\section{Курган}

В лесопосадках, к востоку от ул. Пушкина, находились два небольших (высота - 0,50 м) возвышения, одно из которых Э.А. Сымонович обозначил как "курган 1". В результате раскопок под дерновым слоем вскрыто кольцеобразное скопление довольно крупных $(0,40$ х 0,50 м) камней (табл. 7, I), уложенных в два-три ряда. Это скопление (диаметр - 8 м) частично перекрывало погребения 2 и 3, тогда как в северо-восточном секторе камни практически отсутствовали (табл. 7, I).

В центре сооружения располагалась еще одна небольшая (диаметр - 2,0 м) выкладка из камней меньшего размера. По предположению Э.А. Сымоновича, эта выкладка закрывала входную яму погребения 3 (Сымонович, 1976. С. 6).

При зачистке материка на глубине $0,60-0,80$ м от современной поверхности были выявлены пятна трех погребальных сооружений.

Погребение 1 представляло собой склеп-катакомбу. Круглая в поперечном разрезе входная яма (диаметр - 1,70 м; гл. - 2 м) находилась в северо-восточном секторе (табл.7, I). В погребальную камеру, расположенную к северо-востоку от входной ямы и выходившую за пределы предполагаемой окружности "кургана", вел круто наклонный дромос (1,40 х 1,70 м). Он был заполнен крупными камнями (0,2-0,4 м). Плита трапециевидной формы (1,10 х 0,90 м), закрывавшая вход в камеру, была отвалена (табл. 7, I, III).

Камера прямоугольной формы (2,20 x 1,30 м) была ориентирована по линии СС3 - ЮЮВ, перпендикулярно к дромосу. На ее стенках сохранились остатки коричневого тлена от облицовки деревом. Ровное дно могилы находилось на глубине 4,20 м от современной поверхности и в 3,45 м от уровня зачистки. А дно входной ямы располагалось на 2,10 м выше пола камеры.

В камере были обнаружены разрозненные кости взрослого немолодого человека, вероятно, мужчины, и кости животных от жертвенной пищи. Фрагмент свода черепа человека, находившийся недалеко от северной стенки, может свидетельствовать об ориентировке погребенного головой на северо-запад.

Инвентарь. В средней части южной стенки камеры была найдена краснолаковая кружка (высота - 14,3 см), ручка которой имела продольное рифление. Под отогнутым венчиком проходят горизонтальные желобки линейного орнамента (табл. 8, 1).

В заполнении камеры было обнаружено множество фрагментов железных предметов. В юго-восточном углу, в ногах погребения, находилось, вероятно, непотревоженное скопление железных наконечников стрел (табл. 8, 2, 5). Все они - черешковые, трехлопастные. О том, что захоронение принадлежало воину, свидетельствуют также находки фрагментов линзовидного в сечении лезвия железного обоюдоострого меча (табл. 8, 6, 9). Очевидно, к этому мечу относилось и массивное бронзовое перекрестие ромбической формы (табл. 8,3 ). Оно было найдено в северо-восточном секторе, между входной ямой и северной частью кольцевидного скопления камней, возле бровки. По предположению Э.А. Сымоновича, перекрестие обронили грабители могилы, которые могли также выбросить камни из этой части "кургана" (Сымонович, 1976. С. 8).

Кроме упомянутых, в камере обнаружены обломки еще некоторых железных предметов: стерженька, колечка от упряжи, ножа со следами дерева на черенке (табл. 8, 4, 7, 8, 10). Найдена также янтарная бусина уплощенно-округлой формы (табл. 8, 11). 
Погребение 2 (табл. 9, I, II) было совершено в обычной яме подпрямоугольной формы $(1,5 \times 0,8$ м), ориентированной по линии С33- ЮВВ. Дно ее зафиксировано на глубине 1,20 м от уровня зачистки, следовательно, примерно на 2,00 м от современной поверхности.

В яме находился скелет подростка (девушки?). Положение - на правом боку с подогнутыми ногами головой на восток. Руки также согнуты в локтях. Левая - почти под прямым углом, правая - значительно сильнее, с кистью у лицевой части черепа.

Инвентарь. У затылка погребенной, в юго-восточном углу могилы, стояла миниатюрная лепная мисочка (высота - 4 см) конической формы на кольцевом поддоне (табл. 8, 13). Тесто с примесью шамота, поверхность шероховатая, серо-коричневого цвета.

В районе шеи находились бусы:

1) уплощенно-округлая из глухого черного стекла с белыми полосками (табл. 8, 14);

2) продолговатая бочковидная из коричневатого стекла (табл. 8, 15);

3 ) пронизи из белого полупрозрачного стекла - 2 шт. (табл. 8, 16);

4) мелкие округлые из коричневатого глухого стекла - 2 шт. (табл. 8,17 );

5) биконические "пастовые" голубого и синего цвета - 36 шт. (табл. 8, 18);

6) цилиндрическая из коричневатого полупрозрачного стекла (табл. 8, 19);

7) бочковидные из полупрозрачного стекла с металлической прокладкой - 4 шт. (табл. 8, 20).

Кроме того, обнаружены мелкие бусы из полупрозрачного стекла плохой сохранности, в том числе - сдвоенная округлая, с металлической прокладкой. На груди погребенной находилась тонкая пластинчатая бронзовая лунница с отверстием для подвешивания, украшенная пуансонным орнаментом (табл. 8,12 ).

Погребение 3 (табл. 9, ІІІ), по мнению Э. А. Сымоновича, представляло собой склепкатакомбу (Сымонович, 1976. С. 9). Входная яма подпрямоугольной формы $(1,33$ х 0,87 х 1,80 м) ориентирована по линии С33 - ЮВВ. Камера, отделенная ступенькой (высота - 10 см) также подпрямоугольной формы (1,93 х 0,93 м), расположена к западу от входной ямы и вытянута по единой продольной оси с входной ямой.

В камере находился скелет взрослого человека. Положение - вытянутое на спине головой на С33. Руки согнуты в локтях. Правая - под прямым углом с кистью в районе живота, левая сильно согнута, с кистью у лицевой части черепа. Ноги вытянуты.

Инвентарь (табл. 8, 21-23). В районе шеи обнаружен коротко-цилиндрический бисер египетского фаянса голубого цвета (3 шт.).

При расчистке камней встречалось довольно много обломков керамики, которые принадлежали лепным сосудам как с лощеной поверхностью (табл. 8, 27), так и с шероховатой (табл. 8, 24). Обломки горшка с краем в виде раструба сероватого цвета из глины с примесью шамота были связаны с могильной ямой погребения 1 (табл. 8, 25, 26). Также с этой могилой был связан небольшой фрагмент венчика лепного сосуда со следом ручки, отходящей почти от края (табл. 8, 28). Кроме того, в заполнении могилы погребения 1 найден был фрагмент венчика светлоглиняной амфоры (табл. 8, 29). 


\section{Шурф 2, траншеи 1, 2}

Могила 1 (табл. 10, I). Шурф 2. Катакомба (?).

Форма погребального сооружения не прослежена. Зафиксирован лишь след перекопа, оставленный проходившей над склепом современной канавой. Камни заклада, отделявшие входную яму от камеры, обнаружены на глубине 0,13-0,50 м от уровня зачистки. Диаметр скопления камней около 1,0 м. Приблизительные размеры камеры, судя по находившимся в ней скелетам, - 2,0 х 2,0 м. Среди камней заклада обнаружен крупный фрагмент стенки лепной острореберной лощеной миски из глины коричневатого цвета с примесью шамота (табл. 10, III, 2).

Погребение 1. Обнаружено на глубине 1,65 м от современной поверхности, на 0,15 м ниже основания камней заклада. Это было последнее непотревоженное захоронение, совершенное над двумя остальными, возможно, на глиняной подсыпке. Скелет молодого человека. Большинство костей in situ. Отсутствуют многие фаланги пальцев на руках. Череп лежит на правом виске. Положение вытянутое на спине головой на север. Руки согнуты в локтях, кисти находились на животе. Ноги чуть согнуты в коленях, ступни соединены. Инвентаря не обнаружено.

Погребение 2. К югу от входа. Глубина - 1,75 м от современной поверхности. Скелет молодого человека. Большинство костей in situ. Таз - во фрагментах. Отсутствуют многие ребра, фаланги пальцев рук, стопы. Положение вытянутое на спине головой на З3Ю. Руки раскинуты, ноги вытянуты. Инвентаря не обнаружено.

Погребение 3. Скелет взрослого. Потревожен при последующих захоронениях. Глубина $-1,85$ м от современной поверхности. Раздавленный череп находился под нижней частью позвоночника и под правым локтем погребения 1, тазовые кости - под черепом погребения 2. Видимо, также in situ - кости правой руки, левое плечо, правое бедро, позвоночник. Отдельные кости скелета находились в разных частях камеры. Положение вытянутое на спине головой на CC3. Правая рука согнута в локте, кисть уложена на тазу.

Инвентарь. У левого плеча сохранились обломки бронзовой лучковой проволочной фибулы (табл. 10, III, 1). Возможно, с этим же погребением связана раковина "unio", обнаруженная к северу, на дне камеры.

Могила 2 (табл. 10, II). Траншея 1. Катакомба.

Входная яма не прослежена. Камни заклада выявлены на глубине 0,50-0,70 м от современной поверхности. Камера, имевшая в плане подпрямоугольную форму, находилась к северо-западу от входа. Прослежена она не полностью, так как уходила в западную стенку траншеи, где невозможно было сделать прирезку. Длина ее с юго-запада на северо-восток - около 2,75м. Глубина - 2,48 м от современной поверхности. Обнаружены два разрушенных погребения.

Погребение 1. В северной части камеры. Фрагментированный череп и обломки длинных костей взрослого человека.

Инвентарь. Две большие (5 х 6 см) круглые железные пряжки, вероятно, от конской сбруи, бронзовая бляшка с отверстием в центре (табл. 10, III, 4, 5, 7), несколько бусин:

1) бочковидная из белого стекла с металлической прокладкой (табл. 10, III, б);

2) уплощенно-округлая из темно-серого глухого стекла с голубой волнистой линией (табл. 10, III, 8);

3) уплощенно-округлая ребристая из темно-серого глухого стекла с голубой полосой (табл. 10, III, 9).

В районе погребения лежали также два небольших камня.

Погребение 2. Свод черепа в центральной части камеры. Инвентаря нет. 
В заполнении могилы встречались обломки керамики, из которых интерес представляет ножка светлоглиняной амфоры со следами рифления поверхности (табл. 10, III, 3).

Могила 3 (табл. 11, I). Траншея 1. Детская катакомба. Входная яма, имевшая в плане форму, близкую к трапециевидной, ориентирована по линии СВ - ЮЗ. Длина ее - около 0,75 м, глубина - 0,90-1,05 м от современной поверхности. Сохранились два небольших камня заклада. Овальная в плане камера расположена к северо-востоку от входа и ориентирована по линии С3 - ЮВ. Западная часть не прослежена. Максимальное расстояние в поперечнике с юга на север - 1,40 м, глубина - 1,35 м от современной поверхности.

Обнаружен почти полностью истлевший скелет младенца. Сохранились лишь фрагменты черепа, ребер, плечевых костей. Положение, видимо, вытянутое на спине головой на северо-запад.

Инвентарь. На шее и в ногах обнаружено несколько сильно ирризированных бусин, среди которых находилась одна янтарная, уплощенной в плане подтрапециевидной формы (табл. 11$, II, 1$)$. К западу от черепа стоял миниатюрный лепной горшочек, изготовленный из глины с примесью шамота, с шероховатой серой поверхностью и отогнутым наружу венчиком (высота - 7,8 см; табл. 11, II, 2). Рядом с горшочком лежала лошадиная кость. Мелкие кости животных обнаружены также чуть южнее черепа.

Могила 4 (табл. 11, III). Траншея 1. Катакомба (?). Контуры погребального сооружения не прослежены. На глубине 0,45 м зафиксированы камни заклада, среди которых находилась большая плита ракушечника. Камера была расположена к востоку от входа. Дно ее зафиксировано на глубине 1,53 м. Обнаружены скелеты двоих погребенных, вероятно, мужчины и женщины, лежавших головами ко входу (на запад).

Погребение 1. Взрослая женщина (?). Большинство костей - in situ. Отсутствуют кости стоп, многие фаланги пальцев на руках, ребра и позвонки. Положение вытянутое на спине головой на С33. Руки согнуты в локтях, кисти уложены на тазу. Ноги вытянуты. Под головой камень.

Инвентарь. В районе висков находились серьги из бронзовой проволоки (диаметр - 3 см; табл. 12, 1, 2). У правого бедра найдены: железное кольцо с выступом, видимо, от поясной пряжки (длина - около 5 см; табл. 12, 3), бронзовый колокольчик пирамидальной формы с сохранившимся железным язычком (табл. 12,4) и еще один - полусферический, со следами язычка (табл. 12, 5). У самой головки бедра лежало цилиндрическое пряслице из белого кварцита (диаметр - 3,5 см, табл. 12, б).

В районе шеи находились бусы:

1) крупные (диаметр до 3 см) халцедоновые, округлой формы, серого и голубого цвета 4 шт. (табл. 12, 7);

2) янтарные уплощенно-трапециевидной формы - 3 шт. (табл. 12, 8);

3) бронзовая цилиндрическая пронизка с шишечками (табл. 12, 9);

4) бочковидная из косо перевитых полос белого, желтого, светло-зеленого, темно-синего глухого стекла (табл. 12, 10);

5) округлая плакетка глухого светло-зеленого стекла с желтыми прожилками, в центре ее помещен желтый цветок на белом фоне в обрамлении черной и коричневой полосок (табл. $12,11)$

6) стилизованый скарабей (?) из непрозрачного темно-синего стекла, как бы обернутый полоской глухого белого (чуть голубоватого) стекла (табл. 12, 12);

7) округлая из непрозрачного светло-зеленого стекла с поперечной белой полосой (табл. $12,13)$;

8) округлые и бочковидные из белого стекла с металлической прокладкой - 20 шт. (табл. $12,14,15)$;

9) цилиндрическая из меловой породы (табл. 12, 16);

10) биконические и округлые из синего непрозрачного стекла - 6 шт. (табл. 12, 17, 18); 
11) цилиндрическая из глухого оранжевого стекла (табл. 12, 19);

12) округлая из глухого желтого стекла (табл. 12, 20);

13) биконические из светло-зеленого фаянса (?) - 8 шт. (табл. 12, 21);

14) округлые из глухого бежевого стекла с бело-коричневым глазчатым орнаментом 2 шт. (табл. 12, 22).

Погребение 2. Взрослый мужчина (?). Большинство костей - in situ. Череп на правом виске. Отсутствуют некоторые позвонки и ребра, фаланги пальцев на руках и ногах. В головах находился небольшой камень. Положение вытянутое на спине головой на запад. Правая рука вытянута, кисть, вероятно, была прижата к бедру. Левая рука чуть согнута в локте, кисть - на тазу. Ноги вытянуты.

Инвентарь. У левого бедра найдены железные пряжка с прямоугольной обоймой и распавшийся железный нож (табл. 12, 26, 27). На груди лежала бронзовая фибула с пластинчатой спинкой и кнопкой на конце сплошного пластинчатого приемника (длина - 6,5 см; табл. 12, 25). Над ступнями, выше их на 0,40 м, обнаружены кости животных. Возможно, при этом погребении находилась еще одна крупная голубая халцедоновая бусина.

В заполнении могилы обнаружен небольшой фрагмент стеклянного сосуда зеленоватого цвета, возможно, от слива (табл. 12, 24), а также цилиндрическая бусина из глухого черного стекла с коричнево-белым перистым орнаментом (табл. 12, 23). Кроме того, встречались обломки керамики - лепной шероховатой с примесью шамота (табл. 12,28 ) и чернолощеной (табл. 12, 29), стенок и ручек (в том числе двуствольных) светлоглиняных амфор (табл. 12, 30-32).

Могила 5 (табл. 13, I). Траншея 1. Катакомба. Ограблена в древности.

Входная яма полуовальной в плане формы ориентирована по линии С3 - ЮЗ. Длина ее 0,85 м, дно зафиксировано на глубине 1,42 м. Большой камень, закрывавший вход, был отвален. Он достигал в длину 0,93 м. Часть камней заклада была скинута в камеру грабителями. Камера расположена к северо-западу от входной ямы и ориентирована по линии СВ - ЮЗ. Западную ее часть проследить не удалось, так как она уходила под современный тротуар. В ширину она достигала 2,60 м, дно зафиксировано на глубине 1,96 м.

Инвентарь. В центре, у камня, найден фрагмент бронзовой пластинчатой накладки, вероятно, от шкатулки, с остатками дерева, на гвоздиках по углам (табл. 13, II, 1). Среди камней в камере были беспорядочно разбросаны бусы, среди которых преобладали мелкие гагатовые (28 шт., табл. 13, II, 2-4). Кроме того, найдена фрагментированная янтарная бусина (табл. 13, II, 5). Обнаружен также обломок небольшого в диаметре, но массивного железного кольца (табл. 13, II, 6). В северо-восточной части камеры лежала кость лошади. В заполнении могилы встречалась керамика. Особо следует отметить фрагмент краснолаковой ручки кувшина, край красноглиняной миски с остатками хорошего лака и следом отверстия для ремонта, фрагмент стенки биконического сероглиняного гончарного сосуда с линейным орнаментом и следом прилепа ручки (табл. 13, II, 7-9).

Могила 6 (табл. 13, III). Траншея 1. Катакомба (?). Разрушена в древности.

Форма погребального сооружения не прослежена. На глубине 0,65-0,90 м обнаружены пять камней $(0,25$ х 0,20; 0,50 х 0,40 м), вытянутых по линии СВ - ЮЗ. Под ними находились разрушенные части скелетов троих погребенных.

Погребение 1. Череп ребенка без нижней челюсти, на правом виске. Находился у двух центральных камней, с восточной их стороны. Глубина - 0,95 м.

Погребение 2. Верхняя часть скелета взрослого человека под двумя камнями в северовосточной части скопления. Возможно, in situ - череп, обращенный к западу, часть позвоночника и ребер, плечевые кости. Смещены бедренная, левая локтевая и берцовые кости. Ориентация северо-восточная. Глубина - 1,10 м.

Погребение 3. Череп на правом виске и несколько фрагментов костей к северо-западу от скопления камней. Глубина - 1,10 м. 
Инвентарь. При расчистке могилы обнаружено несколько бусин, среди них подвеска из египетского фаянса голубого цвета в виде скарабея (табл. 13, V, 1).

Могила 7 (табл. 13, IV; 14, I). Траншея 1. Катакомба.

Входная яма не прослежена. Место входа фиксировала плита ракушечника почти квадратной формы $(0,68 \times 0,63$ м), которая была обнаружена на глубине 0,90-0,120 м. Овальная в плане камера $(2,50 x 1,65 \times 1,95$ м) расположена к северо-востоку от входа, вероятно, перпендикулярно к нему, и ориентирована по линии С3 - ЮВ. У входа в камеру, на глубине 1,40 м, выявлено скопление зубов и обломки челюсти лошади. В камере находились скелеты двоих погребенных.

Погребение 1. Непосредственно у входа скелет взрослой женщины (?). Большинство костей - in situ. Отсутствуют кости обеих стоп, а также, за исключением нескольких, - фаланги пальцев на руках. Положение вытянутое на спине головой на северо-запад. Руки согнуты в локтях под прямым углом и уложены на живот. Ноги вытянуты.

Инвентарь. На шее находились бусы:

1) ребристо-цилиндрическая пронизь из прозрачного стекла с металлической прокладкой (табл. 13, V, 2);

2) крупная уплощенно-округлая из полупрозрачного зеленого стекла (табл. 13, V, б);

3) бочковидные из белого полупрозрачного стекла с металлической прокладкой - 6 шт. (табл. 13, V, 10, 11);

4) шаровидные из непрозрачного синего стекла - 24 шт. (табл. 13, V, 12);

5) уплощенно-округлые из янтаря - 16 шт. (табл. 13, V, 13-16).

В 0,20 м к западу от головы стояла лепная полусферическая мисочка на кольцевом поддоне с подлощенной поверхностью желтовато-серого цвета (высота - 3,1 см; табл. 13, VI, 2). Немного дальше, к северо-западу, лежало бронзовое дисковидное зеркальце (диаметр - 5 см, табл. 13, VI, 1), находившееся на равном расстоянии от черепов погребения 1 и 2, поэтому с точностью установить, к которому из них оно относилось, невозможно.

Погребение 2. Скелет взрослой женщины (?). Большинство костей - in situ. Череп повернут лицевой частью к северу. Отсутствуют кости стоп и кистей, многие ребра и позвонки. Положение вытянутое на спине головой на северо-запад. Правая рука согнута под прямым углом и уложена на живот, левая согнута и уложена чуть выше, на грудь, ноги вытянуты. В головах и под голенями - камни.

Инвентарь. На шее и в районе щиколоток находились бусы: 1) мелкие бочковидные из белого полупрозрачного стекла (7 шт.; табл. 13, V, 3, 4); 2) бочковидная из глухого коричневого стекла (табл. 13, V, 5).

Кроме того, при зачистке в разных частях могилы обнаружен бисер: 1) коротко-цилиндрический из египетского фаянса разных оттенков - от бледно-голубого до бирюзового (12 шт.; табл. $13, \mathrm{~V}, 8) ; 2$ ) цилиндрический из полупрозрачного стекла с металлической прокладкой (8 шт.; табл. 13, V, 7). Найдены также цилиндрические пронизи из египетского фаянса бирюзового цвета (6 шт.; табл. 13, V, 9).

Могила 8 (табл. 14, II; 15, I). Траншея 1. Детская катакомба или подбой.

Овальная в плане входная яма ориентирована по линии С3 - ЮВ. Длина ее 0,80 м, глубина $-1,30$ м. Вход заложен несколькими небольшими камнями, обнаруженными на глубине 1,00-1,08 м. Один из них скатился в восточную часть камеры (1,15 х 0,70 х 1,52 м), которая располагалась к северо-востоку от входной ямы и была ориентирована по линии С3 - ЮВ.

У северной стенки обнаружен скелет ребенка плохой сохранности. Большинство костей in situ. Череп на правом виске. Таз - во фрагментах. Полностью истлели многие ребра и позвонки, отсутствуют также кости предплечий, кистей и стоп. Положение вытянутое на спине головой на восток. Правая рука, видимо, вытянута, левая откинута в сторону от туловища или смещена; ноги вытянуты. 
Инвентарь (табл. 15, II). В районе шеи обнаружено несколько штук коротко-цилиндрического бисера из египетского фаянса зеленоватого цвета. Кроме того, найдены крупная сердоликовая бусина бочковидной формы и небольшая бочковидная из прозрачного стекла. Южнее головы находился астрагал мелкого рогатого скота с просверленным отверстием.

Могила 9 (табл. 15, III). Траншея 1.

Форма погребального сооружения с точностью не установлена. Узкая могильная яма имела в плане вытянуто-овальную форму, нехарактерную для камеры катакомбы. Однако в отчете Э.А. Сымоновича упоминается "отчетливый след входной ямы с южной стороны" (Сымонович, 1976. С. 16). Могила (2,0 х 0,75 x 1,65 м) ориентирована по линии С33 - ЮВВ.

Обнаружен скелет взрослого человека. Большинство костей - in situ. Лицевая часть черепа во фрагментах. Отсутствуют кости стоп левой кисти и некоторые фаланги пальцев правой руки. Положение вытянутое на спине головой на СЗ3. Правая рука согнута, кисть уложена на тазу. Левая рука немного согнута, кисть, возможно, была прижата к бедру. Ноги скрещены в голенях. Инвентаря не обнаружено.

Могила 10 (табл. 16, I). Траншея 1. Катакомба или подбой. Ограблена в древности.

Входная яма овальной в плане формы (1,60 х 1,10 х 2,05 м) ориентирована по линии С3 ЮВ. В центральной ее части находились кости лошади. Вход закрывали камни, обнаруженные на глубине 0,60-0,78 м.

Среди них выделялась размерами $(1,00$ х 0,70 м) плита ракушечника. Камера $(1,90$ х 1,25 x 2,55 м), также овальная в плане, расположена к юго-западу от входной ямы и ориентирована по линии С3 - ЮВ. В камере обнаружены разрозненные фрагменты костей человека. Наиболее выразительный фрагмент черепа был найден в южной части могилы. Видимо, погребен был один взрослый человек.

Инвентарь. Находки происходили из заполнения обеих частей могилы, однако большинство их сосредоточено в пределах камеры. Прежде всего следует отметить две бронзовые фибулы. Одна из них - сильно профилированная с нижней тетивой и бусинами на головке и дужке (длина 4,6 см; табл. 16, II, 1). Вторая - фибула-брошь в виде ажурного пластинчатого круга с выступами по краям (диаметр - 3,4 см; табл. 16, II, 5). К изделиям из бронзы относятся также обломки тонкостенного полусферического колокольчика, деформированная обойма, кольцо (от пряжки?), проушная игла (табл. 16, II, 2, 4, 6, 7). Украшения представлены подвеской из стенки раковины округлой формы с отверстием (табл. 16, II, 3) и фигуркой крокодила из египетского фаянса с отбитым хвостиком (табл. 16, II, 13). Кроме того, найдены три бусины: 1) округлая из глухого коричневого стекла с синим глазчатым орнаментом (табл. 16, II, 10); 2) мелкая округлая из глухого белого стекла (табл. 16, II, 11); 3) цилиндрическая из глухого черного стекла с белыми полосками (табл. 16, II, 12). Вероятно, из заполнения входной ямы происходят еще две крупные бусины: 1) уплощенно-округлая свинцовая (табл. 16, II, 8); 2) округлая, усеченно-конической формы в продольном разрезе, из полупрозрачного зеленоватого слоистого стекла (табл. 16, II, 9).

Среди многочисленных фрагментов керамики выделяется почти целый (с восстановленным профилем) лепной горшочек с шероховатой поверхностью желтоватого цвета и примесью шамота в тесте (высота - 11,4 см; табл. 16, II, 19). Найден также выразительный обломок края подобного, но более крупного, сосуда (табл. 16, II, 14). Краснолаковая посуда представлена двумя венчиками полусферических мисок (диаметр - 22,5 см), нижней частью сосуда на кольцевом поддоне (диаметр донца - 4,5 см) и рельефной ручкой (табл. 16, II, 15, 18). Найдены также два фрагмента светлоглиняных амфор - венчика и двуствольной ручки (табл. 16, II, 16, 17).

Могила 11 (табл. 17, I). Траншея 1. Катакомба (?). Ограблена в древности (?).

Входная яма не прослежена. Место входа обозначено плитой ракушечника $(0,60$ х 0,30 м), обнаруженной на глубине 0,80 м. Камера овальной в плане формы (2,25 x 1,30 x 1,95 м) расположена к северо-востоку от входа и вытянута по линии С3 - ЮВ. На дне камеры обнаружены разбросанные кости четырех погребенных. 
Погребение 1. Череп ребенка в южной части камеры (глубина - 0,80-0,90 м). Видимо, остальные кости полностью истлели.

Инвентарь. Рядом с черепом находились бусы:

1) бочковидная из синего полупрозрачного стекла (табл. $17, \mathrm{IV}, 1)$;

2) бесцветные полупрозрачные стеклянные с металлической прокладкой разных форм -

6 шт. (табл. 17, IV, 2-6);

$3)$ в форме параллелепипеда со сглаженными гранями, из глухого белого стекла - 7 шт. (табл. 17, IV, 7);

4) цилиндрические пронизи из глухого красно-коричневого стекла - 7 шт. (табл. 17, IV, 8).

Погребение 2. Части скелета взрослого человека. Череп лежит на левом виске, видимо, in situ. Большинство костей смещено или отсутствует.

Погребение 3. Разрушенный скелет взрослого человека. Череп повернут лицевой частью вниз. Остальные кости перемешаны с костями погребения 4.

Погребение 4. Фрагментированный череп взрослого человека. Условно к погребению отнесены фрагменты таза, бедренные кости, обломки костей рук.

Погребенные взрослые (погребения 2-4) ориентированы головами на северо-запад.

Инвентарь. В заполнении камеры найдена фрагментированная бронзовая проволочная серьга с завязанными концами (табл. 17, IV, 9).

Могила 12 (табл. 17, II). Траншея 2.

Тип погребального сооружения не установлен, так как западную его часть проследить было невозможно. Вскрытая могила округлой в плане формы (диаметр - 3,20 м, глубина 2,70 м) ориентирована по линии ССВ - ЮЮЗ. В южной части, на глубине 1,00 м обнаружены три камня, которые могли представлять собой остатки заклада входа в камеру. Скопление многочисленных камней выявлено и в заполнении могилы. Находки представлены костями животных (череп лошади и кости собаки), а также керамикой: фрагментами ручек различных сосудов - светлоглиняных амфор (табл. $17, \mathrm{IV}, 10-12$ ) и серолощеного кувшина (табл. 17, IV, 13).

Могила 13 (табл. 16, III). Траншея 2. Детская катакомба.

Входная яма полуовальной в плане формы $(0,95$ х 0,76 х 1,40 м) ориентирована по линии CВ - ЮЗ. Вход заложен тремя небольшими камнями. Камера подпрямоугольной формы (ширина - 0,70 м; глубина - 1,50 м) расположена к северо-востоку от входа и ориентирована по линии С3 - ЮВ. Северо-западная ее часть не прослежена. От хрупкого скелета младенца сохранились лишь некоторые фрагменты костей верхней части туловища. Череп находился в северо-западной части могилы. Инвентарь не обнаружен.

Могила 14 (табл. 17, III). Траншея 2. Катакомба.

Входная яма не прослежена. Место входа обозначено двумя камнями заклада у юго-западной части могилы (более крупный достигал размеров 0,50 х 0,50 м). Камера овальной в плане формы (2,00 х 1,35 х 1,67 м), расположенная к северо-востоку от входной ямы, ориентирована по линии С3 - ЮВ. Обнаружены скелеты двоих погребенных.

Погребение 1. Младенец, лежавший непосредственно у входа, вытянуто на спине, головой на северо-запад. Сохранились: фрагментированный череп, обломки ребер, таза, костей рук и ног. Ноги, вероятно, вытянуты. Положение рук установить невозможно. Инвентарь не обнаружен.

Погребение 2. Скелет взрослой женщины (?), лежавшей вытянуто на спине, головой на северо-запад, смещен при захоронении младенца. Череп на правом виске, лицевой частью обращен в южную сторону. Отсутствуют многие кости, таз - во фрагментах. Правая рука согнута и уложена на живот. Левая рука, скорее всего, вытянута. Ноги, видимо, вытянуты и соединены в ступнях.

Инвентарь. В районе шеи и возле правого локтя находились бусы: 1) мелкие округлые из темно-коричневого глухого стекла - 37 шт. (табл. 17, IV, 15); 2) уплощенно-округлая из глухого бирюзового стекла (табл. 17, IV, 14). 
У правого плеча стоял двуручный гончарный сосуд с подлощенной поверхностью бурого цвета (высота - 6,5 см; табл. 17, IV, 16).

Могила 15 (табл. 18, I). Траншея 2. Простая грунтовая могила (?).

Форма погребального сооружения не прослежена. На глубине 0,90 м обнаружен скелет молодой женщины. Большинство костей - in situ. Отсутствуют кости стоп, некоторые фаланги пальцев на руках, отдельные ребра и позвонки. Череп на правом виске. Погребенная лежала вытянуто на спине, головой на северо-восток. Руки согнуты, кисти уложены на таз. Ноги вытянуты.

Инвентарь. В районе шеи находились бусы:

1) бочковидная из глухого коричневого стекла с черным глазчатым орнаментом (табл. 18, II, 2);

2) мелкие бочковидные из глухого черного стекла с рельефной поверхностью - 2 шт. (табл. 18, II, 3);

3) мелкие дисковидные из глухого черного стекла - 3 шт. (табл. 18, II, 4);

4) уплощенно-бочковидные из глухого черного стекла - 2 шт. (табл. 18, II, 5);

5) бочковидная из прозрачного стекла с металлической прокладкой (табл. 18, II, б);

6) мелкие бочковидные из прозрачного стекла - 2 шт. (табл. 18, II, 7);

7) пронизь из голубого фаянса (табл. 18, II, 8).

Между колен стояла краснолаковая кружка с округло-биконическим туловом, украшенная горизонтальными валиками (высота - 9,2 см; табл. 18, II, 1). 


\section{Раскопки 1977 г.}

\section{Описание могил (раскоп I, шурфы 3-6)}

Могила 16. Раскоп I (табл. 19, II, 20, I). Трупосожжение. На глубине 0,65 м выявлено скопление кальцинированных костей (диаметр - 0,95 м), задетое ножом бульдозера. Захоронение безурновое.

Инвентарь. Среди костей обнаружены: дисковидное пряслице, изготовленное из стенки сероглиняного сосуда (диаметр - 3,0 см; табл. 20, IV, 1); фрагменты железных предметов ножа и перевитого стержня (табл. 20, IV, 2, 3). Найдены также бусы и подвески:

1) скарабей из полупрозрачного светло-зеленого стекла (табл. 20, IV, 4);

2) крупная биконическая подвеска из полупрозрачного стекла с металлической прокладкой (табл. 20, IV, 5);

3) уплощенная, квадратная в плане гагатовая бусина (табл. 20, IV, б);

4) крупные бочковидные бусы из полупрозрачного светло-зеленого стекла - 2 шт. (табл. 20, IV, 7);

5) вытянутые бочковидные из глухого белого стекла - 2 шт. (табл. 20, IV, 8);

6) мелкая бочковидная из прозрачного стекла (табл. 20, IV, 9);

7) бочковидные из полупрозрачного стекла с металлической прокладкой -5 шт. (табл. 20, IV, 10-12);

8) вытянутые бочковидные из глухого коричневого стекла (табл. 20, IV, 13);

9) мелкие бочковидные из непрозрачного коричневого стекла с белой поперечной полоской - 2 шт. (табл. 20, IV, 14);

10) бочковидные разных размеров из глухого черного стекла - 18 шт. (табл. 20, IV, 15-18);

11) округлые бусы из глухого стекла разных оттенков (бежевый, зеленоватый, красноватый) с глазчатым, синим и черно-белым, орнаментом - 4 шт. (табл. 20, IV, 19-22); 12) цилиндрическая пронизь из фаянса светло-голубого цвета (табл. 20, IV, 23).

Обломки керамики принадлежат светлоглиняной амфоре и краснолаковой мисочке (табл. 20, IV, 37).

Могила 17 (табл. 18, III; 19, III). Шурф 3.

Разрушена траншеей для труб канализации. Сохранилась часть, которая, скорее всего, принадлежала камере большой катакомбы (2,60 х 1,60 х 2,25 м), имевшей в плане подквадратную форму с закругленными углами и ориентированной по линии С3 - ЮВ. У северо-западного угла могилы на глубине 0,70 м обнаружены два камня. В камере находились останки двоих погребенных.

Погребение 1. Скелет взрослого мужчины (?), лежавшего вытянуто на спине головой на северо-запад. Большинство костей - in situ. Отсутствуют отдельные ребра и фаланги пальцев на руках. Над бедрами находились два камня. Руки и ноги вытянуты.

Инвентарь. На груди лежали две одинаковые бронзовые фибулы с плоской овальной спинкой и кнопкой на конце сплошного приемника (длина - 4,2 см; табл. 18, IV, 2).

У левой руки, левой голени и левой стопы находились три железных трехлопастных наконечника стрел плохой сохранности (табл. 18, IV, 7). У правой стопы найден небольшой кусок железного предмета. У правой голени, с внутренней стороны, лежали три круглых бронзовых пряжки (диаметр - 1,5-1,6 см; табл. 18, IV, 4-б). На тазовых костях сохранились обломки железной пряжки (табл. 18, IV, 8). 
Погребение 2. Кости стоп, голени и обломок левого бедра девушки-подростка (?). Верхняя часть скелета уничтожена современным грабительским подкопом из канализационной траншеи. Положение погребенной, предположительно, вытянутое на спине головой на северо-запад.

Инвентарь. С погребением связаны вещи, найденные местным школьником и переданные экспедиции - золотая серьга с зернью (табл. 18, IV, 1), бусы и бронзовое дисковидное зеркало (диаметр - 4,0 cм). В ногах лежал гончарный сероглиняный флакон с отбитым горлом (диаметр дна - 1,8 см; табл. 18, IV, 3).

Могила 18 (табл. 20, IV, II). Раскоп I. Простая грунтовая яма.

Задето бульдозером. Форма погребального сооружения не прослежена. На глубине 0,80 м обнаружено скопление костей взрослого человека. Позу погребенного установить не удается, можно лишь предположить, что ориентирован он был по линии ССВ - ЮЮЗ.

Инвентарь. Среди костей найдены отдельные невыразительные фрагменты лепной и гончарной керамики.

Могила 19 (табл. 20, III). Раскоп I. Детская катакомба.

Входная яма прямоугольной формы (1,05 x 0,60 х 1,45 м) ориентирована по линии СВ Ю3. Каменного заклада не обнаружено. Камера овальной в плане формы $(1,12$ х 0,60 х 1,90 м) расположена к северо-востоку от входной ямы и ориентирована по линии С3 - ЮВ. У северовосточной стенки лежал скелет ребенка плохой сохранности. Уцелевшие кости - in situ. Череп на левом виске. Таз - во фрагментах. Полностью истлели кости стоп, левой руки, позвоночника. Положение вытянутое на спине головой на северо-запад. Ноги вытянуты.

Инвентарь. В районе шеи обнаружены бусы:

1) бочковидные из непрозрачного зеленоватого стекла с белой полоской -2 шт. (табл. 20, IV, 24, 25);

2) уплощенно-округлые из непрозрачного голубого стекла с белой полоской (табл. 20, IV, 26);

3) бочковидные из бесцветного прозрачного стекла - 2 шт. (табл. 20, IV, 27, 28 );

4) мелкие округлые, уплощенно-округлые и уплощенно-биконические из прозрачного стекла - 6 шт. (табл. 20, IV, 29-34);

5) округло-трапециевидная из белого глухого стекла (табл. 20, IV, 35).

У правого плеча стояла лепная плоскодонная мисочка, изготовленная из глины с примесью шамота, с прилощенной поверхностью серого цвета (диаметр венчика - 7,2 см; табл. 20, $\mathrm{IV}, 36$ ). В заполнении могилы найдено донце чернолакового сосуда (диаметр - 5,0 см; табл. 20, IV, 38).

Могила 20 (табл. 21, I). Раскоп I. Катакомба. Ограблена в древности.

Входная яма, ориентированная по линии север - юг, имела неправильную форму $(2,00 \mathrm{x}$ 1,40 х 1,15 м), так как, по-видимому, была нарушена грабительским лазом. Вход закрывала каменная плита $(0,98 \times$ х 0,60 м), откинутая разрушителями могилы. Камера овальной в плане формы $(1,60$ x 1,10 x 2,20 м) расположена к северу от входа и ориентирована по линии запад восток. Обнаружены части скелетов троих погребенных.

Погребение 1. У входа череп и фрагменты костей рук ребенка. Рядом с черепом - небольшой камень. Ориентация головой на запад.

Инвентарь. В районе шеи находились бусы:

1) бочковидные из прозрачного стекла с металлической прокладкой - 40 шт.

(некоторые - сдвоенные; табл. 21, IV, 1-4);

2) бочковидные из полупрозрачного темно-коричневого стекла - 30 шт. (табл. 21, IV, 5-8);

3) коротко-цилиндрические, дисковидные и уплощенно-округлые из гагата - 49 шт.

(табл. 21, IV, 9-15);

4) цилиндрические из непрозрачного зеленого стекла - 4 шт. (табл. 21, IV, 16-19);

5) фигурно-цилиндрическая пронизь из полупрозрачного белого стекла с металлической прокладкой (табл. 21, IV, 21); 
6) мелкие округлые из коричневого непрозрачного стекла с белой полоской - 13 шт. (табл. 21, IV, 22);

7) мелкие из прозрачного, синего полупрозрачного, желтого полупрозрачного, глухого темно-коричневого стекла - 20 шт. (табл. 21, IV, 20, 23-25).

Погребение 2. Скелет взрослой женщины (?) в центральной части камеры. Большинство костей - in situ. Череп - на левом виске, на двух небольших камнях. Таз и кости ног - во фрагментах. Отсутствуют кисти, стопы, кости правого и левого предплечий, некоторые ребра. Положение вытянутое на спине головой на запад. Ноги вытянуты.

Инвентарь. У правого локтя стояла лепная чашечка с шероховатой поверхностью светло-коричневого цвета, изготовленная из глины с примесью шамота, с углублением в дне неправильной формы (диаметр венчика - 9,0 см; табл. 21, IV, 48).

Рядом находились бусы:

1) уплощенно-биконическая, уплощенно-округлые, бочковидные из прозрачного

бесцветного стекла, некоторые с металлической прокладкой - 59 шт.

(табл. 21, IV, 26-28, 45-47);

2) коротко-цилиндрический бисер из египетского фаянса голубого, белого, темно-синего цветов - 208 шт. (табл. 21, IV, 29-33);

$3)$ бочковидные из коричневого непрозрачного стекла с белой полоской -2 шт.

(табл. 21, IV, 34, 35);

4) округлые из глухого бежевого и красноватого стекла с глазчатым синим орнаментом - 2 шт. (табл. 21, IV, 39, 40);

5) округлые из черного глухого стекла - 3 шт. (табл. 21, IV, 41-43);

6) бочковидная из полупрозрачного коричневого стекла (табл. 21, IV, 44);

7) мелкая из желтого полупрозрачного стекла (табл. 21, IV, 37);

8 ) уплощенно-бочковидные из глухого серого стекла - 3 шт. (табл. 21, IV, 38 ).

Кроме того, обнаружен бисер из стекла разных цветов: белого прозрачного, черного, синего, зеленого - 7 шт.

Погребение 3. Верхняя часть скелета взрослого человека. У входа, вероятно, in situ череп, часть позвоночника и ребер, кости левой руки, согнутой в локте (кисть отсутствует). Ориентация головой на восток.

Инвентарь. К погребению отнесены бусы:

1) уплощенно-округлая из янтаря (табл. 21, IV, 49);

2) бочковидные из глухого черного стекла - 7 шт. (табл. 21, IV, 50-52);

3) округлые из глухого стекла бежевого или красного цвета с глазчатым

бело-синим орнаментом - 6 шт. (табл. 21, IV, 53-55);

4) округлые из непрозрачного серого стекла - 10 шт. (табл. 21, IV, 56-58, 60);

5) мелкая бочковидная из глухого красного стекла (табл. 21, IV, 59).

По-видимому, из могилы 20 происходят также бусы бочковидной формы из глухого стекла белого и коричневого цвета, полупрозрачные с металлической прокладкой (всего 7 шт.). Кроме того, в могиле найден небольшой камень со сточенной стороной, возможно, предназначенный для растирания румян.

Могила 21 (табл. 21, II). Раскоп І. Детская катакомба. С запада задета могилой 31.

Входная яма не совсем правильной овальной формы (1,30 х 0,85 x 1,20 м), ориентированная по линии С3 - ЮВ, была заполнена камнями. Камера овальной в плане формы $(1,70$ x 1,25 x 1,30 м), расположенная к северу от входа, ориентирована по линии СВВ - ЮЗ3. На дне, в западной части, лежала плита ракушечника $(0,40$ х 0,30 м), а рядом с ней - небольшой камень. Обнаружены три погребения.

Погребение 1. К востоку от каменной плиты скелет младенца плохой сохранности. In situ фрагментированный череп, части позвоночника, таза, бедер. Положение вытянутое на спине головой на север.

Инвентарь. Обнаружены бусы: 
1) бочковидная из светло-зеленого глухого стекла (табл. 21, III, 1);

2) шаровидная из прозрачного бесцветного стекла (табл. 21, III, 2);

3) плоские ромбические из полупрозрачного светло-коричневого стекла - 4 шт. и несколько обломков (табл. 21, III, 3, 4);

4) мелкие бочковидные (2 шт.) и уплощенно-округлая из полупрозрачного

светло-коричневого стекла (табл. 21, III, 5-7);

5) бисер из глухого темно-синего стекла - 13 шт. (табл. 21, III, 8);

6) округлая из глухого бежевого стекла с глазчатым орнаментом бело-синего цвета (табл. 21, III, 9).

Погребение 2. К югу от погребения 1 фрагментированный череп и мелкие обломки костей младенца, ориентированного головой на запад.

Погребение 3. Напротив входа, у южной стенки камеры, скелет младенца плохой сохранности. In situ - фрагментированный череп, отдельные позвонки, диафизы плечевых, бедренных костей и костей предплечья. Положение вытянутое на спине головой на запад. Левая рука вытянута, правая - чуть согнута в локте. Ноги вытянуты.

Инвентарь. У черепа, а также между левой рукой и черепом погребения 2 обнаружены бусы:

1) округлая из глухого красного стекла с глазчатым орнаментом бело-синего цвета

(табл. 21, III, 10);

2) мелкая округлая из фаянса зеленовато-голубого цвета (табл. 21, III, 11);

3 ) шаровидная ребристая из голубого фаянса (табл. 21, III, 12);

4) округлая с перемычкой по центру из глухого полосатого красно-белого стекла (табл. 21, III, 13);

5) цилиндрическая пронизь из красного глухого стекла (табл. 21, III, 14).

Могила 22 (табл. 22, I). Раскоп I. Катакомба.

Входная яма, ориентированная по линии север - юг, имела в плане форму, близкую к трапециевидной $(1,70$ х 1,50 х 1,15 м). Вход закрыт камнями (0,40 х 0,30-0,40 м). Камера овальной в плане формы $(2,40$ х 1,50 х 1,75 м) расположена к северу от входа и ориентирована широтно. Обнаружены останки троих или четверых погребенных.

Погребение 1. Фрагменты костей ребенка в юго-западной части камеры. Здесь же находились обломки длинных костей лошади, кости птицы, небольшие камни.

Инвентарь. Условно к погребению 1 отнесены обнаруженные в разных местах юго-западной части камеры бусы:

1) цилиндрические из полупрозрачного желтого стекла, сдвоенные (8 шт.) и

одинарные - 14 шт. (табл. 22, IV, 10, 11);

2) цилиндрические и сдвоенные из глухого белого стекла - 16 шт. (табл. 22, IV, 12-14);

3 ) цилиндрическая из глухого зеленого стекла (табл. 22, IV, 15);

4) мелкая бочковидная из глухого белого стекла (табл. 22, IV, 16);

5) мелкие бочковидные и уплощенно-бочковидные из полупрозрачного голубого стекла -

21 шт. (табл. 22, IV, 17-19);

6) дисковидная из темно-синего полупрозрачного стекла (табл. 22, IV, 20);

7) плоские ромбические из полупрозрачного светло-коричневого стекла -8 шт.

(табл. 22, IV, 21, 22);

8 ) катушковидная из глухого белого стекла (табл. 22, IV, 23);

9) кубическая из меловой породы (табл. 22, IV, 24);

$10)$ бисер из полупрозрачного, коричневого, глухого белого и синего стекла - 6 шт. (табл. 22, IV, 25, 26);

11) округлая дольчатая из глухого черного стекла с белыми полосками (табл. 22, IV, 27);

12) дисковидная из стенки раковины (табл. 22, IV, 28).

Погребение 2. Череп и мелкие обломки костей ребенка в западной части камеры. Инвентарь не обнаружен. 
Погребение 3. Части скелета младенца в восточной части камеры, под двумя упавшими камнями заклада (0,40 x 0,30 м). In situ - фрагментированный череп, диафизы бедренных, больших и малых берцовых костей. Положение вытянутое на спине головой на северо-запад. Ноги вытянуты.

Инвентарь. В ногах обнаружен бисер из полупрозрачного зеленоватого стекла - 2 шт. (табл. 22, IV, 8) и мелкая округлая бусина из глухого белого стекла (табл. 22, IV, 9).

Погребение 4. Скелет младенца плохой сохранности в восточной части камеры. In situ фрагментированный череп, отдельные ребра, диафизы плечевых, бедренных, больших берцовых костей. Положение вытянутое на спине головой на северо-запад. Ноги вытянуты.

Инвентарь. Справа от черепа найдены четыре астрагала мелкого рогатого скота, один из которых имел сточенный край. Рядом лежала подвеска из бронзовой монеты (табл. 22, IV, 4). В районе шеи находились бусы:

1) округлая из глухого белого стекла (табл. 22, IV, 29);

2) бочковидная из полупрозрачного стекла с металлической прокладкой (табл. 22, IV, 30);

3) округлая, дольчатая (сдвоенная) из полупрозрачного стекла бутылочного цвета (табл. $22, \mathrm{IV}, 31)$.

Могила 23 (табл. 22, II). Раскоп I. Катакомба. Нарушена при устройстве входной ямы могилы 31.

Входная яма неправильной формы (1,35 x 1,30 х 1,15 м) ориентирована по линии С33 ЮВВ. Камера овальной формы (2,50 х 2,00 х 1,30 м) расположена к северо-востоку от входа и ориентирована по линии СВ - ЮЗ. В камере находилось несколько камней разных размеров (самые крупные - 0,5 х 0,3 м), в юго-западной части прослежена подмазка дна зеленоватой глиной. Обнаружены части скелетов троих погребенных.

Погребение 1. Верхняя часть скелета взрослого человека. Большинство сохранившихся костей - in situ. Отсутствуют кости правой ноги, а также кости левой голени и стопы. Положение вытянутое на спине головой на юго-запад. Руки согнуты в локтях, кисти уложены на тазу. Левое бедро отведено, возможно, смещено.

Инвентарь. На левой стороне грудной клетки находились бусы. Вероятно, к ним относились:

1) бочковидные и уплощенно-бочковидные из прозрачного и непрозрачного белого стекла - 46 шт., одна сдвоенная (табл. 22, IV, 32-34);

2) бочковидные, уплощенно-бочковидные и биконические из полупрозрачного синего стекла - 16 шт. (табл. 22, IV, 35-39);

3) бочковидные и уплощенно-бочковидные из полупрозрачного светло-коричневого стекла - 2 шт. (табл. 22, IV, 40, 41);

4) уплощенно-биконические и округлые из полупрозрачного темно-коричневого стекла - 4 шт. (табл. 22, IV, 42);

5) плоские ромбические из полупрозрачного светло-коричневого стекла - 2 шт. (табл. 22, IV, 43);

6) фрагментированная из глухого серого стекла - 1 шт. (табл. 22, IV, 44).

Погребение 2. Часть скелета взрослого человека. Возможно, in situ - фрагментированный череп, правая часть грудной клетки, кости правой руки без кисти, фрагменты таза, бедра. Положение вытянутое на спине головой на юго-запад. Правая рука вытянута, ноги вытянуты.

Инвентарь. В районе левой части грудной клетки обнаружены бусы. Вероятно, к ним относились две крупные округлые ребристые из голубого фаянса (табл. 22, IV, 45, 46).

Погребение 3. Части разрушенного скелета взрослого человека. Возможно, in situ, фрагментированный череп. Позвоночник и ребра отсутствуют. Кости рук и бедра смещены. Положение, вероятно, вытянутое на спине головой на юго-запад.

Инвентарь. У правого локтя найдены обломки массивной железной лучковой фибулы (длина - 7,8 см; табл. 22, IV, 7). У левой руки - донце сосуда со следами красного лака (диаметр6,0 см; табл. 22, IV, б). 
Могила 24 (табл. 22, III). Раскоп I. Разрушена в древности. Тип погребального сооружения не установлен. Овальная в плане могила (1,38 x 0,88 x 1,50 м) ориентирована по линии ССВ - ЮЮЗ. В южной части выявлены "следы прослеживаемой входной ямы" (Сымонович, 1977. C. 11).

Обнаружены разрозненные кости от одного или двух детских скелетов.

Инвентарь. Среди костей найден обломок железного ножа (табл. 22, IV, 5) и цилиндрическая бусина из глухого белого стекла (табл. 22, IV, 1).

Могила 25 (табл. 23). Раскоп I. Катакомба. Ограблена в древности.

Входная яма вытянутой прямоугольной формы (3,45 х 0,85 x 1,47-1,55 м) ориентирована по линии СВ - ЮЗ. Примерно на середине длины она прерывалась первым каменным закладом. Вторая плита заклада (0,70 х 0,45 м), отваленная грабителями, лежала плашмя над самым входом в камеру. Не исключено, что отрезок между двумя каменными закладами представлял собой дромос. Стенки камеры, расположенной к северо-востоку от входа, прослежены лишь частично, поэтому о форме и размерах судить сложно. Глубина камеры $-2,55$ м.

В могиле обнаружены части разрушенных скелетов троих погребенных. Небольшое скопление костей находилось в северо-западной части камеры, а основная их масса, в том числе три фрагментированных черепа, была выброшена за плиту заклада, во входную яму. Здесь же сконцентрирован почти весь инвентарь.

У черепа погребения 1 найдена черноглиняная личина, представляющая собой полуовальную пластину с выпуклыми глазами и выступом, обозначающим нос (табл. 23, III, 24). К бронзовым изделиям относятся: два гвоздика, вероятно, от деревянной шкатулки; серьги из проволоки с нескрепленными и замыкающимися концами в виде крючков; мелкие фрагменты пластинок и пронизок (табл. 23, III, 1-4). Эту серию дополняет обломок бронзовой лучковой фибулы с фигурной обмоткой спинки (табл. 23, III, б). Лучше сохранилась бронзовая сильно профилированная фибула с бусинами на головке и дужке, многовитковый пружиной и верхней тетивой, но, судя по описанию и рисунку, без крючка (длина - 3,7 см; табл. 23, III, 5; Сымонович, 1977. C. 12, табл. XVIII, 19). Керамика представлена обломком стенки лепного сосуда и венчиком краснолаковой острореберной миски (табл. 23, III, 23). Бусы найдены как в скоплении во входной яме, так и в северо-западной части камеры:

1) 14-гранные из гагата - 4 шт. (табл. 23, III, 7-10);

2) цилиндрическая из гагата (табл. 23 , III, 11);

3 ) пронизь из полупрозрачного стекла с металлической прокладкой (табл. 23, III, 12);

4) округлые и цилиндрические бусы из глухого белого стекла - 7 шт. (табл. 23, III, 13-18);

5) плоская трапециевидная и усеченно-биконическая из янтаря - 2 шт.

(табл. 23, III, 19, 20);

6) коротко-цилиндрический и усеченно-биконический бисер из зеленовато-голубого фаянса - 2 шт. (табл. 23, III, 21, 22).

Могила 26 (табл. 24). Раскоп І. Тип погребального сооружения не определен. Выявленная могила овальной формы (1,60 х 0,92 х 1,40 м) ориентирована по линии С3 - ЮВ. В отчете Э.А. Сымоновича отмечено, что входная яма, возможно, находилась с южной стороны (Сымонович, 1977. С. 12). Однако камни заклада отсутствовали. Обнаружены скелеты двоих погребенных.

Погребение 1. Скелет взрослой женщины (?) под южной стенкой могилы. Прослежена подмазка дна зеленоватой глиной. Большинство костей - in situ. Положение на спине головой на северо-запад с чуть отведенными в северную сторону ногами, при этом одна из них, левая, чуть согнута в колене. Руки раскинуты, правая немного согнута в локте. Череп повернут к северу.

Инвентарь. Обнаружены два скопления бус. В районе шеи найдены:

1) уплощенно-округлая из глухого красного стекла (табл. 24, II, 1);

2) сдвоенная цилиндрическая из глухого темно-серого стекла (табл. 24, II, 2); 
3) фрагментированная из полупрозрачного синего стекла (табл. 24, II, 3);

4) уплощенно-округлые и усеченно-биконические из глухого и полупрозрачного белого стекла, некоторые - с металлической прокладкой - 9 шт. (табл. 24, II, 4-6);

5) плоская ромбическая из полупрозрачного желтого стекла (табл. 24, II, 7);

6) округлая из глухого черного стекла с белым и бежевым глазчатым орнаментом (табл. 24, II, 8);

7) округлая дольчатая из синего фаянса (табл. 24, II, 9);

8) вытянутая бочковидная из полупрозрачного коричневого стекла с белой полоской (табл. 24, II, 10);

9) бочковидная из глухого черного стекла с белой полоской (табл. 24, II, 11);

10) округлые бусы разных форм и размеров из сердолика - 52 шт. (табл. 24, II, 12-19).

В районе стоп найдены:

1) коротко-цилиндрический бисер из голубого и светло-голубого фаянса - 61 шт. (табл. 24, II, 20-22);

2) округлые бусы разных размеров и форм из полупрозрачного стекла с металлической прокладкой - 5 шт. (табл. 24, II, 23, 24);

3) округлые бусы разных форм из глухого белого и серого стекла - 11 шт.

(табл. 24, II, 25-27);

4) цилиндрическая из глухого зеленого стекла (табл. 24, II, 28);

$5)$ цилиндрическая и бочковидная из глухого красно-коричневого стекла -2 шт.

(табл. 24, II, 29, 30);

6) мелкие из полупрозрачного белого и желтого стекла - 2 шт.

Погребение 2. Скелет взрослой женщины (?) под северной стенкой могилы. Большинство костей смещено, вероятно, при совершении первого захоронения. Скорее всего, погребенная лежала вытянуто на спине головой на северо-запад.

Инвентарь. В районе шеи обнаружены бусы:

1) округлые разных форм и размеров из глухого и прозрачного белого стекла, некоторые с металлической прокладкой - 25 шт. (табл. 24, II, 31-35, 41-43);

2) цилиндрическая из глухого черного стекла с белыми и желтыми полосками (табл. 24, II, 36);

3) округлая дольчатая из синего фаянса (табл. 24, II, 37);

4) плоская ромбическая из полупрозрачного желтовато-зеленоватого стекла (табл. 24, II, 38);

5) округлая из глухого голубого стекла с белым глазчатым орнаментом (табл. 24, II, 39);

6) бочковидная из полупрозрачного светло-коричневого стекла (табл. 24, II, 40).

Могила 27 (табл. 25, I). Раскоп I.

Детская катакомба. Входная яма не прослежена. Камера овальной в плане формы $(1,52$ x 0,95 x 1,10 м) ориентирована по линии С3 - ЮВ. Вход с южной стороны обозначен закладом камней. Основная необработанная плита (длиной не менее 0,60 м) нависала над могилой. В восточной части обнаружен скелет младенца плохой сохранности. Многие кости полностью истлели. In situ - фрагменты костей ног, сходящихся у ступней, фрагменты черепа. Судя по всему, положение вытянутое на спине головой на СЗ3.

Инвентарь. Под камнями заклада, на уровне черепа погребенного, стояли два лепных сосуда: горшочек с шероховатой поверхностью серого цвета (диаметр венчика - 5,4 см; табл. 25, III, 9) и овальный в плане светильник с поперечной перегородкой, имевший прилощенную поверхность серого цвета (длина - 9,8 см; табл. 25, III, 8). Оба сосуда изготовлены из глины с примесью шамота.

Среди костей найдены бусы:

1) подвеска грушевидной формы из полупрозрачного темно-синего стекла с белыми полосками - из двух фрагментов (табл. 25, III, 1); 
2) плоская трапециевидная подвеска из глухого коричневого стекла с белым и желтым орнаментом (табл. 25, III, 2);

3 ) уплощенно-бочковидная из глухого бежевого стекла с белой полоской (табл. 25, III, 3);

4) округлые из глухого коричневого стекла с глазчатым бело-синим орнаментом - 3 шт.

(табл. 25, III, 4);

5) округло-эллипсоидная полихромная - синее полупрозрачное стекло в сочетании

с глухими черными и белыми полосками (табл. 25, III, 5);

6) плоские ромбические из полупрозрачного желтого и "медового" стекла - 3 шт.

(табл. 25, III, 6, 7).

В заполнении могилы встречались мелкие обломки бронзовых и железных предметов.

Могила 28 (табл. 25, II). Раскоп І. Тип погребального сооружения не установлен.

Выявлена округлая могильная яма (1,45 x 1,45 x 1,85 м). В нижней части находился развал многочисленных камней, возможно, составлявших заклад входа в камеру. Часть из них провалилась и перекрыла скелет погребенной взрослой женщины (?). Большинство костей - in situ. Отсутствуют некоторые фаланги пальцев рук и ног, отдельные ребра. Положение вытянутое на спине головой на ССЗ. Руки согнуты в локтях, кисти уложены на тазу. Ноги вытянуты (правая - чуть согнута). Под головой погребенной находились небольшие камни, а под туловищем выявлены следы коричневатого тлена и кусочки дерева (а может быть, коры или кошмы).

Инвентарь. Обнаружены бусы. В районе шеи: 1) усеченно-конические из горного хрусталя -4 шт. (табл. 25, III, 10); 2) дисковидная янтарная (табл. 25, III, 11); 3) цилиндрические пронизи из глухого красного стекла - 18 шт. (табл. 25, III, 12). В районе ног: 1) катушковидная из полупрозрачного стекла с металлической прокладкой (табл. 25, III, 13); 2) округлые из полупрозрачного белого стекла, некоторые - с металлической прокладкой - 19 шт, из них три сдвоенные (табл. 25, III, 14-17).

К северо-западу от головы стояла буролаковая полусферическая миска на кольцевом поддоне (диаметр венчика - 12,5 см; табл. 25, III, 22). На правую руку надет бронзовый проволочный браслет с концами в виде стилизованных змеиных головок (табл. 25, III, 18). Справа от таза находилось бронзовое дисковидное зеркальце в обломках с остатками деревянного футляра. У левого плеча лежали фрагменты железного ножа и крючкообразного предмета (табл. 25, III, 20). Кроме того, в могиле были найдены: пряслице, изготовленное из стенки сосуда (диаметр - 3,0 см; табл. 25, III, 23), фрагменты бронзовой лучковой фибулы с узкой пластинчатой спинкой и нижней тетивой (табл. 25, III, 19 ), кусок кремня и обломок железного кольца (табл. 25, III, 21).

Могила 29 (табл. 26). Раскоп І. Катакомба. Ограблена в древности.

Входная яма прямоугольной в плане формы (1,70 x 1,35 x 1,15 м) ориентирована по линии ЮЮЗ - ССВ. Камера, расположенная к северу от входной ямы, видимо, также имела прямоугольную форму и была ориентирована по линии ССЗ - ЮЮВ. Западная часть уходила под стенку раскопа, где не было возможности сделать прирезку, поэтому длину ее с точностью определить не удалось, ширина - около 1,80 м, глубина - 2,00 м. Камни заклада, отваленные грабителями, вывернуты бульдозером. В могиле обнаружены разрозненные кости, принадлежавшие не менее чем двоим погребенным. В восточной части камеры находились фрагменты костей ног. Развал костей также обнаружен во входной яме.

Инвентарь. Во входной яме, среди развала костей, найдены бусы:

1) крупная бочковидная из глухого зеленого стекла со светлым глазчатым орнаментом (табл. 26, II, 1);

2) грушевидная из глухого желтовато-бежевого стекла (табл. 26, II, 2);

3) коротко-цилиндрический бисер из голубого и светло-серого фаянса - 11 шт.

(табл. 26, II, 3-5);

4) усеченно-биконические и уплощенно-округлые из глухого коричневого стекла - 16 шт. (табл. 26, II, 6-9).

Кроме того, найдены следующие вещи: обломки железных предметов, в том числе кон- 
чик ножа (табл. 26, II, 11); буролаковая полусферическая миска, украшенная по тулову двумя горизонтальными врезанными линиями (диаметр венчика - 16,6 см; табл. 26, II, 15). Бронзовые изделия представлены фрагментами спирально скрученной в виде цилиндра проволоки (табл. 26, II, 10), двумя сильно профилированными фибулами с бусинами на головке и дужке. Одна - с многовитковой пружиной и верхней тетивой с крючком (длина $-6,5$ см; табл. 26, II, 12), вторая - с короткой пружиной и нижней тетивой (длина - 7,4 см; табл. 26, II, 14).

Могила 30 (табл. 27, I). Раскоп I.

Катакомба. Форма погребального сооружения до конца не прослежена, так как с востока к могиле примыкала канализационная траншея, из которой, возможно, был сделан подкоп. Камера подквадратной в плане формы (2,25 х 2,40 х 2,38 м) ориентирована, скорее всего, по линии С3 - ЮВ. Расположение входной ямы с западной стороны (Сымонович, 1977, С.15) вызывает сомнение. А такие факты, как странная форма, небольшой размер, отсутствие каменного заклада сомнение это усиливают.

В камере обнаружены останки семерых погребенных.

Погребение 1. Второе с южной стороны. Скелет взрослой женщины (?). Большинство костей - in situ. Отсутствуют кисти и некоторые фаланги пальцев на ногах. Положение вытянутое на спине головой на запад. Череп на правом виске, лицевой частью обращен в южную сторону. Правая рука чуть согнута в локте, кисть, возможно, была прижата к бедру. Левая рука согнута в локте под прямым углом, кисть, вероятно, лежала на тазу. Ноги вытянуты.

Инвентарь. На груди лежала бронзовая проволочная фибула с кнопкой на конце пластинчатого приемника (длина - 5,7 см; табл. 27, II, 12). Рядом находились две бусины - янтарная (высота - 1,5 см; табл. 27, II, 7) и из меловой породы (диаметр - 1,5 см; табл. 27, II, 8). Возле правого плеча лежала бронзовая фибула со щитком на головке и довольно высоким пластинчатым приемником (длина - 3,5 см; табл. 27, II, 13). Рядом находились бочковидные бусины из глухого белого стекла (0,7-0,8х0,7-0,8 cм; табл. 27, II, 9-11). Здесь же найдены бронзовые предметы: пронизка, серьги (диаметр - 2 см; табл. 27, II, 1-4) и проволочное кольцо с заходящими друг на друга концами (диаметр - 2 см; табл. 27, II, 5). С этим погребением связана также находка глиняного пряслица усеченно-конической формы (высота - 3 см; табл. 27, II, б).

Погребение 2. Скелет взрослой женщины (?) в центральной части камеры. Большинство костей - in situ. Таз - во фрагментах. Отсутствуют некоторые фаланги пальцев рук и ног. Череп слегка повернут к левому плечу. Положение вытянутое на спине головой на С33. Руки согнуты в локтях, кисти уложены на тазу. Ноги вытянуты, стопы соединены. Под скелетом выявлены следы коричневого тлена.

Инвентарь. У левой стопы стоял гончарный сероглиняный кувшин с отбитым горлом, сглаженным в изломе (диаметр края - 4,3 см; табл. 27, III, 10). Поверхность - со следами лощения. Под горлом - горизонтальный валик. Возле левого локтя лежала бронзовая, сильно профилированная фибула с гребнем на дужке и высоким приемником (длина - 6,0 см; табл. 27, III, 11). В районе шеи находились бусы:

1) фрагментированная плоская ромбическая из полупрозрачного коричневато-желтого стекла - 1 шт. + обломки (табл. 27, III, 1);

2) фрагмент округлой бусины из полупрозрачного синего стекла (табл. 27, III, 2);

3) округлая дольчатая из голубого фаянса (табл. 27, III, 3);

4) фрагмент цилиндрической бусины из полупрозрачного зеленого стекла (табл. 27, III, 4);

5) мелкие уплощенно-округлые бусы из полупрозрачного зеленого стекла - 15 шт. (табл. 27, III, 5);

6) мелкие округлые из полупрозрачного красного, белого, синего стекла - 10 шт. (табл. 27, III, 6-8);

7) мелкие округлые и цилиндрические бусы из полупрозрачного и глухого стекла черного и коричневого цвета -5 шт. (табл. 27, III, 9). 
В ногах найдено глиняное бочковидное пряслице (высота - 2,5 см; табл. 27, III, 12) и обломки ножа плохой сохранности. Возле головы лежало бронзовое колечко.

Погребение 3 (табл. 29). Скелет взрослой женщины (?). В северной части камеры. Большинство костей - in situ. Отсутствуют отдельные ребра и фаланги пальцев на руках и ногах. Череп на левом виске, лицевой частью обращен к северу. Положение вытянутое на спине, головой на С33. Правая рука согнута в локте почти под прямым углом, кисть уложена на тазу. Левая рука слегка согнута, кисть прижата к бедру. Ноги вытянуты. У левой стопы лежала большая кость животного (крупный рогатый скот).

Инвентарь. Погребение характеризуется выразительным набором бронзовых фибул. Слева от нижней челюсти находилась круглощитковая брошь (диаметр - 2,6 см.) с четырьмя кружочками-выступами, расположенными симметрично. Вещь эта украшена эмалью (табл. 28, 2; 29, II). Ниже левой ключицы и у правой головки бедра лежали две сильно профилированные фибулы с гребнем на дужке и высоким приемником (длина - 5,0 и 4,1 см; табл. 28, 3, 5). " Возле бедер" (Сымонович, 1977. С. 17) обнаружена трапециевидная застежка (длина - 4,8 см) с полукруглым щитком и петелькой наверху. На ножке - круглый выступ с эмалью. Поперечные красные и синие полосы эмали украшали также спинку застежки (табл. 28, 1). На правой стороне грудной клетки лежала сильно профилированная фибула с трапециевидной ножкой (длина 4,0 см; табл. 28, 4), а на левой стороне - крупная, плоская янтарная подвеска овальной в плане формы (табл. 30, 43).

Кроме фибул, к погребению относятся еще несколько бронзовых предметов. На правое запястье был надет проволочный браслет с завязанными концами (табл. 28, 9). Пальцы рук украшали перстни с овальными щитками (табл. 28, 6, 7). Рядом лежало бронзовое колечко со связанными концами (табл. 28, 10).У правого колена (снаружи) находились еще два массивных бронзовых кольца (диаметр - 3,2-3,5 см; табл. 28, 8, 11), а у правого бедра найдены обломки бронзовой иглы. Комплекс вещей у правой ноги включал также несколько (шесть ?) крупных халцедоновых бусин голубого и дымчато-серого цвета (табл. 31, I ).

При погребенной обнаружено множество разнообразных бус. К сожалению, точное количество по каждому из типов установить невозможно. В районе шеи находились:

1) 14-гранные из глухого белого стекла - 3 шт.? (табл. 28, 16-18);

2) цилиндрические из глухого белого стекла - 2 шт.? (табл. 28, 19, 20);

3) бочковидные, уплощенно-округлые и цилиндрические из меловой породы - 4 шт.?

(табл. 28, 23-26);

4) округлые халцедоновые - 3 шт.? (табл. 28, 27-29);

$5)$ плоские, в основном овальные в плане, и округлые из янтаря - 20 шт.?

(табл. 28, 21, 22, 30-38);

6) бледно-розовые коралловые - 2 шт.? (табл. 28, 13,14);

7) мелкие уплощенно-округлые из полупрозрачного зеленого стекла - 2 шт.?

(табл. 28, 15).

Помимо крупной янтарной подвески, на груди находились бусы: 1) округлые халцедоновые - 2 шт.? (табл. 30, 32, 33); 2) бочковидные из меловой породы - 2 шт.? (табл. 30, 34,35); 3) 14-гранная из глухого белого стекла (табл. 30, 36). Возможно, на груди найдены круглые плоские, овальные в плане, бусы из янтаря (табл. 30, 38, 41, 42) и более мелкие янтарные (табл. 30, 37, 40), а также пронизь из полупрозрачного стекла (табл. 30, 39).

В районе правого запястья находились бусы :

1) бочковидные из полупрозрачного стекла с металлической прокладкой - 13 шт., одна - сдвоенная (табл. 30, 1-4);

2) цилиндрические из глухого красно-коричневого стекла (табл. 30, 5-7);

3) янтарные бусы разных форм - 20 шт. (табл. 30, 9-14);

4) 14-гранные из глухого белого стекла - 6 шт. (табл. 30, 19-24);

5) округлая и цилиндрическая из меловой породы (табл. 30, 26, 27); 
6) коралловые бледно-розового цвета (табл. 30, 15-18);

7) гагатовая с циркульным орнаментом (табл. 30, 8).

Бусы были найдены также в районе левого запястья: 1) бронзовая пронизь (табл. 30, 25); 2) янтарные -2 шт. (табл. $30,28,29$ ); 3) бочковидная из меловой породы (табл. 30, 30); 4) цилиндрическая из глухого красно-коричневого стекла (табл. 30, 31).

С погребением 3 также связана находка глиняного пряслица усеченно-конической формы (высота - 2,5 см; табл. 28, 12).

Погребение 4. Скелет взрослого человека у северной стенки могилы. Большинство костей - in situ. Таз, лицевая часть черепа и кости рук - во фрагментах. Отсутствуют: ребра в нижней части левой стороны груди, полностью - фаланги пальцев рук и отдельные - на ногах. Положение вытянутое на спине головой на С33. Правая рука чуть согнута в локте, кисть, видимо, была прижата к бедру. Левая рука согнута в локте почти под прямым углом, кисть лежала на животе.

Инвентарь. С погребением могут быть связаны лишь находки обломков бронзового браслета (табл. 31, II, 2), железного ножа (табл. 31, II, 7) и фрагмента гончарной сероглиняной миски на кольцевом поддоне (табл. 31, II, 9).

Погребение 5. Скелет подростка под южной стенкой могилы. Большинство костей - in situ. Почти полностью отсутствуют кости стоп и правой кисти. Лицевая часть черепа обращена в южную сторону. Положение вытянутое на спине головой на запад. Руки слегка согнуты в локтях, кисти лежали на тазу. Ноги вытянуты.

Инвентарь. Вплотную к правой ноге лежал железный меч плохой сохранности (длина 0,45 м). У кисти правой руки найдено бронзовое навершие этого меча, имевшее форму шайбы с четырьмя продольными выступами (табл. 32, б). Рядом находились железный кинжал (длина - 28 см; табл. 32, 7) и античный антропоморфный терракотовый сосуд с одной ручкой в виде актера, изображающего Селена (высота - 17, 2 см; табл. 32, 8). Слева от черепа стояли один на другом еще два сосуда. Внизу - лепная коническая миска на кольцевом поддоне с шероховатой поверхностью желтовато-серого цвета (диаметр венчика - 11, 4 см; табл. 32, 1). На одну треть она была заполнена плотной меловой породой. Сверху, как бы в виде крышки, находилась гончарная буролаковая полусферическая миска (диаметр венчика - 14,2 см; табл. 32, 2).

На груди находились бусы: 1) цилиндрическая из меловой породы (табл. 32, 3); 2) мелкие округлые из полупрозрачного зеленого стекла - 2 шт. (табл. 32, 4, 5). Кроме того, с погребением связана находка крупной округлой халцедоновой бусины (табл. 32, 9).

Погребение 6. Череп взрослого человека в юго-восточной части камеры. Остальные кости, вероятно, уничтожены современным подкопом из траншеи канализации.

Инвентарь. В районе шеи находилась гривна (во фрагментах) из бронзовой перевитой проволоки с изогнутыми в виде крючков, сужающимися концами (табл. 31, II, б). С погребением связаны также обломки железного кольца (табл. 31, II, 3).

Погребение 7. В отчете Э.А. Сымоновича указано, что данное захоронение совершено в овальной, вырытой в дне склепа яме (2,15 x 0,73 х 2,52 м), ориентированной по линии С3 - ЮВ. Яма была перекрыта погребением 4 (Сымонович, 1977. С.15). При этом она выходит довольно далеко за пределы северной стенки камеры катакомбы. Подобная ситуация совершенно не характерна для позднескифского погребального ритуала. Не исключено, что захоронение 7 было совершено в индивидуальной могиле и не связано с катакомбой.

Обнаружен скелет взрослого человека. Большинство костей - in situ. Отсутствуют отдельные ребра, большая часть костей стоп и фаланги пальцев на руках. Положение вытянутое на спине головой на северо-запад. Правая рука согнута, кисть лежала на тазу. Левая рука вытянута, кисть, видимо, была прижата к бедру. Ноги скрещены в голенях - правая перекрывала левую.

Инвентарь. У левого плеча лежала железная лучковая фибула (длина - 7,5 см; табл. 31, II, 4). В районе правого запястья обнаружена округлая бусина из темно-синего непрозрачного стекла (табл. 31, II, 1). 
В заполнении могилы были найдены фрагменты донцев гончарного и лепного сосудов, ручек амфор - двуствольной и профилированной, кремневая пластина (табл. 31, II, 8) и бронзовая сильно профилированная фибула с гребнем на спинке и высоким приемником (длина 4,0 см; табл. 31, II, 5).

Могила 31 (табл. 33). Раскоп І. Катакомба (?). Ограблена в древности.

Входная яма, ориентированная по линии север - юг, плохо прослежена, поскольку она частично перекрывала могилу 28. Возможно, участок, круто понижавшийся в сторону камеры, представлял собой дромос (глубина - 2,88 м). В северной его части лежала отваленная грабителями плита заклада $(1,30$ х 0,8 м), которую подпирали более мелкие камни. Некоторые из них обрушились в расположенную к северу камеру. Устройство последней необычно - две прямоугольные площадки (2,30 x 1,00 м), отделенные уступом в 0,30 м, которые имели ровное, твердое дно белесого цвета, достигавшее в ближайшей к входу, южной части, глубины 3,32 м, а в дальней, северной, - 3,00 м. Камни заклада, видимо, были переброшены грабителями на более высокую площадку. На камнях обнаружены два черепа, на нижней площадке - еще один череп. Кроме того, по всей камере были разбросаны кости, принадлежавшие, как и черепа, взрослым погребенным.

Инвентарь. Большинство находок было сосредоточено на нижней площадке камеры. В северо-западном углу стоял лепной ладьевидный светильник, изготовленный из глины с примесью шамота (длина - 21 см, табл. 33, III, 12). На шероховатой поверхности черно-коричневого цвета сохранились следы нагара.

Также на нижней площадке найдены обломки железного оружия: кинжала (длина -27 см), рукояти меча с прямым перекрестием, наконечника копья (длина - 19 см), скипевшихся наконечников трехлопастных черешковых стрел (табл. 33, III, 1-4). Кроме того, обнаружены фрагменты трех железных ножей (табл. 33, III, 5, 6, 11). К деталям конской упряжи относились части железных удил, фигурных бляшек со следами тонкой золотой облицовки (табл. 33, III, 9, 10) и, возможно, бронзовое кольцо (диаметр - 3 см; табл. 33, III, 8). В могиле найдены и другие бронзовые предметы - обломки шильца и перстенька. К набору режущих орудий прилагался четырехгранный точильный брусок (длина - 5,4 см; табл. 33, III, 7).

Необычна находка фрагмента свода черепа человека с просверленным отверстием. Возможно, специально для погребения были изготовлены из мелоподобного вещества крупные бусы цилиндрической и бочковидной формы - 9 шт. (высота 1,6-1,9 см; табл. 33, III, 1-3). Одна из них имела два крестообразно расположенных канала.

В заполнении входной ямы найдена округлая дольчатая бусина из глухого белого стекла (диаметр - 1,2 см; табл. 33, II, 4).

Могила 32 (табл. 34). Шурф 4. Катакомба.

Входная яма разрушена канализационной траншеей, обнаружены лишь крупные камни заклада. Округлая в плане камера $(2,40$ × 2,10 x 2,10 м), ориентирована по линии С3 - ЮВ. Вход в нее находился, скорее всего, с южной стороны, где стенка была разрушена. Обнаружены части скелетов троих погребенных.

Погребение 1. Нижняя часть скелета взрослого человека (женщины ?) у входа. In situ нижняя часть позвоночника, отдельные ребра, фрагментированный таз, кости предплечья и кисти левой руки, бедренные, большие и малые берцовые кости. Отсутствуют кости стоп и отдельные фаланги пальцев руки. Положение вытянутое на спине головой на северо-запад. Левая рука вытянута, кисть прижата к бедру. Ноги вытянуты. В ногах погребенной лежал фрагментированный череп.

Инвентарь. У левого плеча лежал фрагмент бронзового кольца со стеклянной вставкой. На месте правого плеча и несколько южнее находились обломки бронзовых и железных предметов. У кисти левой руки найдены кусочки железа. Рядом, видимо, был положен мешочек, содержавший три бронзовых перстня и бронзовое кольцо с выступами - в обломках (табл. 34, II, 1-5). 
У левой руки и в районе шеи погребенной, обнаружены бусы:

1) цилиндрическая ребристая из непрозрачного синего стекла

(длина - 1,5 см; табл. 34, II, 6);

2) дисковидная из глухого зеленоватого стекла (диаметр - 2 см; табл. 34, II, 7);

3) цилиндрическая из глухого черного стекла с поперечными белыми полосками

(длина - 2,8 см; табл. 34, II, 8);

4) бочковидные и уплощенно-округлые из сердолика - 62 шт. (табл. 34, II, 9-16);

5) катушковидные из глухого белого стекла - 2 шт. (табл. 34, II, 17, 18);

6) сдвоенные цилиндрические из глухого белого стекла - 2 шт. (табл. 34, II, 19);

7) мелкая цилиндрическая из непрозрачного белого стекла (табл. 34, II, 20);

8) коротко-цилиндрический и дисковидный бисер из гагата - 62 шт. (табл. 34, II, 21-23);

9) подвески из гагата - 2 шт. (табл. 34, II, 24, 25).

Погребение 2. Нижняя часть скелета девушки-подростка (?) в центре камеры. In situ несколько позвонков, таз, бедренная и большие бедренные кости. Сохранились также отдельные разбросанные кости в верхней части туловища. Положение вытянутое головой на СЗ. Ноги вытянуты.

Инвентарь. Ко второму погребению отнесена серия вещей в районе отсутствующей головы и у западной стенки могилы. К ним относится краснолаковая острореберная чашечка (диаметр венчика - 10,2 см; табл. 34, II , 42), в которую был положен стеклянный флакон с шаровидным туловом, узким горлом и отогнутым венчиком (диаметр венчика - 1,2 см; табл. 34, II , 41). Рядом находились остатки дерева от шкатулки, содержавшей румяна, охру и кусочек смолистого вещества. Севернее найдены два глиняных пряслица бочонковидной и усеченно-конической формы (высота - 1,8-2,0 см; табл. 34, II, 39, 40), а также нижняя часть терракотовой гермы, разбитой в древности. Несколько кусков верхней части статуэтки были найдены в различных местах могилы и ее удалось восстановить почти полностью (высота - 26 см). Герма имела четырехугольную, полую внутри, форму на пьедестале (6,8 х 5,2 см), расчлененном горизонтальными параллельными врезанными линиями. На месте рук - трапециевидные выступы. Посередине ровной лицевой стороны статуэтки проходит неглубокая вертикальная борозда, прерываемая неотчетливым изображением мужских гениталий. При этом голова явно женская, с косой, спускающейся на левое плечо. Лицо обрамляет большой головной убор в виде расходящихся лучей (диаметр - 8,5 см). Сзади статуэтка не моделирована, имеет простую, округлую плоскую форму. Внизу, между двух горизонтальных врезанных линий, до обжига, вероятно, было процарапано имя мастера (табл. 35).

У левого бедра находились обломки двух перстней (табл. 34, II, 36), видимо, украшавших пальцы левой руки. У левого колена, с внутренней стороны лежал бронзовый конический колокольчик с удлиненно-овальным язычком (табл. 34, II, 35). У правого колена, вероятно, случайно оказались фрагменты бронзового браслета (табл. 34, II, 37). На месте головы находилось бронзовое дисковидное зеркало со следами деревянного футляра (диаметр - 6,4 см; табл. 34, II, 43).

Среди разбросанных костей верхней части туловища найдены бусы:

1) плоская подвеска подквадратной в плане формы из глухого серого стекла с мозаичным орнаментом в виде человеческого лица (табл. 34, II, 34);

2) в форме параллелепипеда из полупрозрачного серого стекла - 2 шт. (табл. 34, II, 31);

3) шаровидная из глухого черного стекла (табл. 34, II, 33);

4) сдвоенные цилиндрические из глухого белого стекла - 2 шт. (табл. 34, II, 27);

5) сдвоенная цилиндрическая из глухого коричневого стекла (табл. 34, II, 28);

6) катушковидная из глухого белого стекла (табл. 34, II, 29);

7) коротко-цилиндрический бисер из голубого фаянса - 1 шт. (табл. 34, II, 30);

8) подвески из гагата - 3шт. (табл. 34, II, 26);

9) обломок бусины из хрусталя (табл. 34, II, 32). 
Кроме того, в могиле найден фрагмент бронзовой пронизи (табл. 34, II, 38).

Погребение 3. Скелет взрослого мужчины у северной стенки камеры. Большинство костей - in situ. Правая плечевая кость смещена. Отсутствуют: верхняя часть грудной клетки, отдельные фаланги пальцев ног и левой руки. Положение вытянутое на спине головой на северозапад. Правая рука согнута, кисть, вероятно, лежала на тазу. Левая рука вытянута, кисть прижата к бедру.

Инвентарь. Вдоль левой голени лежал железный меч в обломках, плохой сохранности (длина - 50 см). У правой стопы находилась кучка скипевшихся железных черешковых, трехлопастных стрел (7 шт.?).

Могила 33 (табл. 36, I). Раскоп I. Катакомба (?).

Место входа обозначено несколькими камнями заклада с западной стороны. Камера неправильной в плане формы (1,70 x 1,60 х 1,50 м), расположенная, видимо, к востоку или северо-востоку от входа, ориентирована по линии СВ - ЮЗ. В камере обнаружены скелеты двоих погребенных.

Погребение 1. Скелет взрослого мужчины (?). Под северной стенкой камеры. Большинство костей - in situ. Отсутствуют кисти и отдельные фаланги пальцев ног. Положение вытянутое на спине головой на запад. Череп на левом виске, склонен к левому плечу, лицевая часть обращена на восток. Левая рука вытянута, кисть, видимо, была прижата к бедру. Правая рука согнута, кисть лежала на животе. Ноги вытянуты. Под верхней частью скелета прослежена подмазка дна могилы зеленоватой глиной.

Инвентарь. В районе шеи найдены фрагменты бронзовой серьги из перевитой проволоки с петлей и крючком на концах, а также бронзовые пронизки (табл.36, II, 1-4). Рядом находился крупный фрагмент рифленой стенки амфоры.

Погребение 2. Части скелета взрослого человека в центре камеры. Большинство костей смещено. Возможно, in situ - большие берцовые и некоторые кости стоп. Отсутствуют многие кости верхней части туловища. Фрагменты черепа находились у локтя правой руки погребения 1. Скорее всего, положение вытянутое на спине головой на запад. Инвентаря не обнаружено.

Могила 34 (табл. 36, III). Раскоп I. Простая грунтовая яма.

В западной части повреждена входной ямой и каменным закладом катакомбы 27. Могила овальной в плане формы (2,00 x 0,90 х 0,80 м) ориентирована по линии запад - восток. Обнаружен скелет взрослого человека плохой сохранности. Большинство уцелевших костей - in situ. Череп раздавлен камнями. Таз - во фрагментах. Отсутствуют кости стоп, кистей, отдельные ребра, большая часть позвонков. Положение вытянутое на спине головой на запад, левая рука согнута, кисть, видимо, лежала на тазу. Правая рука согнута под прямым углом, кисть - на груди. Ноги вытянуты.

Инвентарь. Справа на груди сохранились обломки железного предмета. Под левой ключицей лежала крупная бронзовая проволочная фибула среднелатенской схемы с верхней тетивой (длина - 9,7 см; табл. 36, IV, 5). В районе шеи находились бусы: 1) цилиндрические и дисковидные из глухого темно-серого стекла - 17 шт. ? (табл. 36, IV, 1, 2); 2) цилиндрическая из полупрозрачного стекла с металлической прокладкой (табл. 36, IV, 3); 3) цилиндрическая из глухого белого стекла (табл. $36, \mathrm{IV}, 4)$.

Могила 35 (табл. 37, I). Шурф № 5. Катакомба.

Входная яма, очевидно, уничтожена канализационной траншеей, которая нарушила также южную стенку округлой в плане камеры (2,20 х 2,00 х 2,20 м), ориентированной по линии запад - восток. Обнаружены останки двоих погребенных.

Погребение 1. В центре камеры почти полностью истлевший скелет взрослого человека (женщины?). In situ - фрагментированный череп, фрагмент левого плеча и костей ног. Положение, видимо, вытянутое на спине, головой на запад.

Инвентарь. Возле истлевших костей таза выявлены остатки деревянной шкатулки с амулетами и украшениями. В их составе - несколько мелких бронзовых предметов (табл. 37, II, 1 , 
4), возможно, к ним относился перстень со стеклянной вставкой (табл. 37, II, 2), а также литая ажурная подвеска в виде сферы из одного горизонтального и двух вертикальных толстых круглопроволочных колец с рядами выступов и большой круглой петлей для подвешивания (табл. 37, II, 3). Бусы, в основном, округло-ребристые из голубого фаянса (табл. 37, II, 8-19). Интересен экземпляр усеченно-биконической формы, свитый из зеленовато-коричневого стеклянного жгута (табл. 37, II, 20).

У черепа стояла краснолаковая острореберная чаша. Тулово ее усеченно-конической формы со слегка вогнутыми стенками, бортик также чуть вогнут, дно немного понижается в центре (диаметр - 10,5; табл. 38, 43). Другой сосуд, краснолаковая тарелка, находился в центре камеры, справа от погребенной. Тулово усеченно-конической формы на кольцевом поддоне, бортик почти прямой, чуть скошенный внутрь (диаметр - 12,8 см). Лак имеет металлический оттенок, на дне - клеймо в виде кружка из насечек (табл. 38, 42). Возле первого сосуда лежали два глиняных пряслица - цилиндрической и усеченно-конической формы (высота - 2,2 и 1,4 см; табл. $38,10,11)$.

В районе шеи находились бронзовые предметы: "смычковая" одночленная фибула с плоской спинкой и нижней тетивой (длина - 3,0 см; табл. 38, 3); фрагменты тонкой круглой пластинки (табл. 38,6 ) и наконечник пояса, возможно, служивший подвеской (длина $-2,0$ см; табл. $38,5)$. Ниже на туловище найдены еще две бронзовые сильно профилированные фибулы с бусинами на головке и спинке, кнопкой на конце пластинчатого приемника и нижней тетивой (длина - 4,6 см; табл. 38, 1, 2). Несколько южнее, в районе правого плеча, лежала бронзовая одночленная лучковая фибула с верхней тетивой и высокой дужкой с максимальным прогибом в верхней части (длина $-6,3$ см; табл. 38,4 ). К западу от краснолаковой тарелки находились бронзовый колокольчик с железным язычком усеченно-конической формы (диаметр - 2,2 см; табл. 38,7 ) и бронзовый круглопроволочный браслет с обрубленными концами (диаметр $-3,5$ см; табл. 38, 8). К востоку от тарелки обнаружены фрагменты железного предмета (табл. 38, 9).

Судя по обозначению на этикетке, у левой руки найдены бусы:

1) коротко-цилиндрические гагатовые - 18 шт. (табл. 38, 12-15);

2) подвески в виде скарабеев из фаянса зеленоватого и синего цвета - 2 шт.

(табл. 38, 18, 19);

3) грушевидная из бесцветного полупрозрачного стекла (табл. 38,16 );

4) округлая из глухого черного стекла с белым глазчатым орнаментом ( табл. 38,17$)$;

5) округлые сердоликовые - 12 шт. (табл. 38, 20-25);

6) цилиндрическая из полупрозрачного стекла золотистого цвета (табл. 38, 26);

7) бочковидная из полупрозрачного стекла с металлической прокладкой (табл. 38,27 ;

8 ) уплощенной подквадратной формы из горного хрусталя (табл. 38,28 ).

Возможно, в районе правой руки были также найдены бусы:

1) округлые серлодиковые - 9 шт. (табл. 38, 29-32);

2) коротко-цилиндрический бисер из гагата - 45 шт. (табл. 38, 33-37);

3) цилиндрическая пронизь из полупрозрачного стекла с металлической прокладкой (табл. 38, 38);

4) округлые из полупрозрачного белого стекла с металлической прокладкой - 2 шт. (табл. 38, 39, 41);

5) сдвоенная из прозрачного бесцветного стекла (табл. 38, 40).

В тексте отчета упоминаются бусы в районе шеи, что соответствует и обозначениям на плане могилы (Сымонович 1977. С. 30; табл. 37, I). Однако в коллекции они не обнаружены. Возможно, были перепутаны этикетки.

Погребение 2. Почти полностью истлевший скелет ребенка под северной стенкой камеpы. In situ - фрагментированный череп, фрагменты костей рук и ног. Положение вытянутое на спине головой на восток.

Инвентарь. К востоку от черепа лежали два глиняных пряслица усеченно-конической 
формы (диаметр - 2,8; 3,6 см; табл. 39, 6, 7) и одно свинцовое, уплощенное (диаметр - 2,3 см; табл. 39, 5). Рядом находился точильный брусок (длина - 5,6 см; табл. 39, 9). На груди найдены две бронзовые фибулы. Одна из них - одночленная "смычковая" с плоской спинкой и нижней тетивой (табл. 39, 4). Вторая - шарнирная дуговидная с рельефной, гребенчатой, спинкой и трапециевидной ножкой, украшенной пуансонным орнаментом. На пластинчатом приемнике имеется небольшое отверстие (табл. 39, 2).

В районе правой руки найдены два бронзовых круглопроволочных браслета. Один - с расплющенными, заходящими друг на друга зооморфными окончаниями с пуансонным орнаментом (диаметр - 7,0 х 5,0 см; табл. 39, 10). Второй - с окончаниями в виде шишечек (диаметр - 6,5 см; табл. 39, 11). С погребением 2 связана также находка необычного крестообразного предмета, состоявшего из бронзового, круглого в сечении, стержня с надетой на него двухпетельчатой обоймой (табл. 39, 1).

На шее находилось ожерелье, состоявшее из двух видов бус: 1) округлых сердоликовых 44 шт. (табл. 40, 1-9); 2) цилиндрических и бочковидных из глухого темно-серого, почти черного, стекла - 24 шт. (табл. 40, 10-15). Множество бус было найдено и в других местах погребения 2. В районе левой руки:

1) сердоликовые разных форм и размеров - 20 шт. (табл. 40, 16-20);

2) бочковидная из полупрозрачного белого стекла с металлической прокладкой (табл. 40, 21);

3) бочковидная из глухого черного стекла (табл. 40, 22);

4) бочковидная из полупрозрачного золотисто-зеленоватого стекла (табл. 40, 23);

5) дисковидная из глухого красного стекла (табл. 40, 24);

6) цилиндрическая пронизь из глухого красного стекла (табл. 40, 25);

7) коротко-цилиндрическая из глухого белого стекла (табл. 40, 26);

8) подвески в виде скарабеев из зеленовато-голубого фаянса - 2 шт. (табл. 40, 27, 28).

В районе браслета с окончаниями в виде шишечек:

1) усеченно-биконические из глухого черного стекла - 5 шт. (табл. 40, 29);

2) сердоликовые разных форм - 5 шт. (табл. 40, 30-34);

3 ) округлая из белого фаянса (табл. 40, 35);

4) цилиндрическая из глухого черного стекла (табл. 40, 36);

5) подвески в виде скарабеев из голубого фаянса - 3 шт. (табл. 40, 37-39).

В районе браслета с зооморфными окончаниями:

1) сердоликовые разных форм и размеров - 7 шт. (табл. 40, 40-46);

2) уплощенно-бочковидная из глухого красного стекла с белым орнаментом (табл. 40, 47);

$3)$ усеченно-биконические из глухого черного стекла - 15 шт. (табл. 40, 48);

4) шаровидные из глухого черного и красного стекла - 2 шт. (табл. 40,49$)$;

5) вытянутые усеченно-биконические из гагата - 4 шт. (табл. 40, 50, 51);

6) подвески в виде скарабеев из голубого и зеленоватого фаянса - 3шт. (табл. 40, 52-54). В районе ног: 1) округлая сердоликовая (табл. 40, 55); 2) коротко-цилиндрический бисер из голубого фаянса - 24 шт. (табл. 40, 56, 57). Кроме того, в коллекции представлены:

1) бочковидная из глухого бежевого стекла (табл. 40, 58);

2) бочковидные из глухого красного стекла с темным пятнистым орнаментом - 3 шт. (табл. 40, 59, 60, 62);

$3)$ цилиндрическая из глухого коричневого стекла (табл. 40, 61);

4) округлые ребристые из голубого фаянса - 10 шт. (табл. 40, 63-72); уплощенная усеченно-биконическая, свитая из непрозрачного стеклянного синего с белым жгута (табл. 40, 73).

В заполнении могилы найдены мелкие поделки из бронзы: круглопроволочные серьги (табл. 39, 3, 8); фрагменты круглопроволочного браслета с фигурно-уплощенными несомкну- 
тыми концами (диаметр - 7,0 см; табл. 39, 12); фрагменты зеркала (скорее всего, плоского дисковидного); фрагменты пластинок и швейной иглы.

Могила 36 (табл. 36, V). Раскоп I. Подбой.

Контуры входной ямы не прослежены. Вход в подбой закрыт пятью камнями $(0,30$ х 0,30; 0,25 х 0,20 м), уложенными в ряд на глубине 0,67 м. Сам подбой имел в плане прямоугольную с закругленными углами форму $(1,73$ х 0,52 х 0,97 м) и был ориентирован по линии ССВ ЮЮЗ. Реконструируемая высота ниши - 0,50-0,55 м. Обнаружен скелет взрослого человека (женщины?), большинство костей - in situ. Отсутствуют кости стоп, отдельные фаланги пальцев рук. Положение скорченное на правом боку головой на ССВ. Череп - на правом виске, лицевая часть обращена к западу. Правая рука вытянута и слегка отведена от туловища. Левая рука согнута в локте под прямым углом, кисть уложена на тазу. Ноги согнуты в коленях.

Инвентарь. Возле костей голени левой ноги стояли два лепных сосуда. Один из них миниатюрная коническая мисочка на кольцевом поддоне с шероховатой поверхностью желтоватого цвета (диаметр - 6,8 см; табл. 36, VI, 19). Другой - горшочек удлиненных пропорций с максимальным расширением тулова несколько ниже середины высоты, на выделенном поддоне; поверхность шероховатая, у края прилощенная, черного цвета (диаметр венчика - 7,4 см; табл. 36, VI, 20). Во втором сосуде находилось глиняное пряслице усеченно-биконической формы (табл. 36, VI, 18).

В районе шеи находились бусы:

1) катушковидные из непрозрачного стекла цвета слоновой кости - 4 шт. (табл. 36, VI, 1 );

2) катушковидные из непрозрачного голубовато-зеленого стекла - 3 шт. (табл. 36, VI, 2);

3)цилиндрические сдвоенные из полупрозрачного золотистого стекла - 2 шт. (табл. 36, VI, 3);

4) цилиндрическая из полупрозрачного золотистого стекла (табл. 36, VI, 4);

5) уплощенная усеченно-биконическая из светлого зеленовато-голубого фаянса (табл. 36, VI, 5);

6) цилиндрическая и бочонковидная из глухого серо-коричневого стекла -3 шт. (табл. 36, VI, 6-8).

На груди также было найдено несколько бусин:

1)цилиндрическая из глухого светло-бежевого стекла (табл. 36, VI, 9);

2) катушковидная из непрозрачного белого стекла (табл. 36, VI, 10);

3) катушковидная из непрозрачного голубовато-зеленого стекла (табл. 36, VI, 11);

4) фрагмент цилиндрической бусины из коричневого с белым стекла (табл. 36, VI, 14);

5) фрагмент цилиндрической бусины из непрозрачного стекла (табл. 36, VI, 16).

Кроме того, найдены: шаровидная ребристая бусина из голубого фаянса (табл. 36, VI, 15); коротко-цилиндрический бисер из голубого фаянса - 2 шт. (табл. 36, VI, 12, 13) и фрагмент бронзовой свернутой пластины , возможно, от фибулы (табл. 36, VI, 17).

Могила 37 (табл. 41). Раскоп 1. Детская катакомба.

Входная яма трапециевидной в плане формы (1,0х0,6-1,0 х 1,85 м) ориентирована по линии СВ - ЮЗ. В ней обнаружен развал камней заклада, среди которых находились обломки керамики и кости выброшенного и разрушенного детского скелета. Основная плита подтреугольной формы упала в могильную камеру (1,05 x 0,95 х 2,10 м), расположенную к северовостоку от входа и ориентированную по линии С3 - ЮВ.

Инвентарь был сосредоточен во входной яме. Найден лепной горшочек с шероховатой поверхностью темного цвета, декорированный двумя М-образными налепами (диаметр венчика - 8,3 см; табл. 41, II, б). Во входной яме обнаружены еще два сосуда: краснолаковая острореберная чаша (диаметр венчика - 12,6 cм) с усеченно-коническим туловом, бортик с наклоном внутрь, дно плоское (табл. 41, II, 7), и краснолаковый кувшин с округлым рифленым туловом на кольцевом поддоне (табл. 41, II, 8). Стенки горла сильно вогнуты, венчик отогнут, образуя массивный выступ-ребро (диаметр венчика - 6,8 см). Ручка профилированная, с одним желобком. 
Среди черепков в заполнении могилы был венчик лепной полусферической миски с шероховатой поверхностью (диаметр - 10, 5 см; табл. 41, II, 5). Бронзовые изделия представлены пронизками и ворворкой (табл. 41, II, 2-4). У черепа, в северо-западном углу входной ямы, лежало красноглиняное усеченно-коническое пряслице (табл. 41, II, 1). На одном из камней в могиле выявлены следы обработки.

Могила 38 (табл. 42, I). Раскоп I. Детская катакомба.

Входная яма полуовальной в плане формы (1,25 х 0,75 x 1,05 м), была ориентирована по линии север - юг. Камера подпрямоугольной в плане формы (0,97 х 0,52 х 1,40 м), расположена к северу от входной ямы и ориентирована по линии запад - восток.

В камере обнаружен скелет ребенка плохой сохранности. Большинство уцелевших костей - in situ. Отсутствуют кости голени левой ноги, обеих стоп, многие ребра, фаланги пальцев рук. Положение вытянутое на спине головой на С33. Руки согнуты в локтях, кисти находятся на тазу. Ноги вытянуты.

Инвентарь. На левой стороне груди лежала бронзовая сильно профилированная фибула с бусинами на головке и дужке и крючком для тетивы (табл. 42, II, 10). У левого плеча обнаружен астрагал барана. Возле головы находились бронзовые серьги в виде колечек с сомкнутыми концами (табл. 42, II, 8, 9).

В районе шеи находились бусы:

1) округлая ребристая из полупрозрачного зеленоватого стекла (табл. 42, II, 1 );

2) мелкие бочковидные из полупрозрачного белого стекла с металлической прокладкой 5 шт. (табл. 42, II, 2);

3) мелкие округлые из глухого коричневатого стекла - 2 шт. (табл. 42, II, 3, 5);

4) шаровидные из глухого коричневого стекла с белым покрытием (табл. 42, II, 4, 6, 7).

В заполнении могилы встречались фрагменты профилированных ручек амфор

(табл. 42, II, 11-13).

Могила 39 (табл. 42, III). Раскоп I. Катакомба.

Входная яма, контуры которой не прослежены, скорее всего, была ориентирована по линии СВ - ЮЗ. Камера, расположенная к северо-востоку от входной ямы и ориентированная по линии С3 - ЮВ, имела округлую форму (1,90 х 2,00 х 1,40 м). Вход заложен двумя крупными плитами ракушечника. В камере, на разных уровнях, были разбросаны в беспорядке отдельные кости, принадлежавшие двоим погребенным - взрослому и ребенку.

Инвентарь. Керамика представлена лепной полусферической миской на кольцевом поддоне с шероховатой поверхностью желто-серого цвета (диаметр венчика - 8,4 см; табл. 42, IV, 9), а также нижней частью краснолакового сосуда на кольцевом поддоне (диаметр дна - 4,7 см; табл. 42, IV, 8). Найдено несколько бронзовых предметов: кольцо с несомкнутыми концами в виде стилизованных змеиных головок; наконечник пояса в виде тонкой полуовальной пластины с тремя отверстиями; бронзовый стержень, видимо, служивший язычком пряжки; обломки бронзовой иглы и маленькая полусферическая бляшка (табл. 42, IV, 1-4). Кроме того, обнаружены бусы: усеченно-биконические из сердолика и одна мелкая, округлая, сильно ирризированная, из стекла коричневого цвета (табл. 42, IV, 5-7).

Могила 40 (табл. 43). Раскоп І. Катакомба. Ограблена в древности.

Входная яма, ориентированная по линии СВ - Ю3, имела овальную в плане форму $(1,80$ х 1,40 x 2,55 м). Ее юго-западная часть забита камнями, среди которых была обнаружена миниатюрная лепная курильница, представляющая собой горшочек с отверстиями на выпуклых боках (диаметр венчика - 5,2 см; табл. 43, II, 32). Кроме того, здесь были обнаружены венчики двух сосудов: гончарного сероглиняного и лепного приземистого, имевшего почти цилиндрическую форму, украшенного широким валиком-воротником (табл. 43, II, 33, 34). В центральной части входной ямы находились кости ног лошади, обломки железных удил плохой сохранности, бронзовое массивное кольцо (диаметр - 2,3 см; табл. 44, II, 3, 7), а также большое количество железных трехлопастных черешковых наконечников стрел (табл. 44, II, 8-18). В заполне- 
нии входной ямы обнаружены фрагмент рифленой стенки амфоры и кусочек тонкостенного стеклянного сосуда. Вероятно, из заполнения происходят также два стеклянных округлых жетона, которые были изготовлены из венчика полупрозрачного стеклянного сосуда желтоватого цвета, украшенного горизонтальной врезанной линией. Края жетонов аккуратно обломаны и сглажены (диаметр - 2,8 см; табл. 43, II, 30, 31).

Кроме того, в отчете Э.А. Сымоновича упоминаются два бронзовых предмета: засов (?) от шкатулки (табл. 43, II, 28) и фрагмент лучковой фибулы (табл. 43, II, 27). Место находки не указано ( Сымонович 1977. С. 25).

Камера, расположенная к северо-востоку от входной ямы и ориентированная по линии С3 - ЮВ, имела в плане форму, близкую к прямоугольной (2,00 x 1,00 х 2,70 м). Вход закрыт тремя плитами ракушечника. Выявлены следы подмазки дна зеленоватой глиной, а также коричневого древесного тлена. В камере обнаружены части скелетов двоих погребенных.

Погребение 1. Ближайшее ко входу. Принадлежало, вероятно, взрослому мужчине. In situ - кости правой руки без кисти, бедра, фрагменты таза и берцовых костей, отдельные ребра, а также, вероятно, фрагментированный череп и левая ключица. Левая плечевая кость смещена. Остальные кости отсутствуют. Положение вытянутое на спине головой на северо-запад. Правая рука согнута в локте, кисть, вероятно, была уложена на тазу. Ноги вытянуты.

Инвентарь. Вдоль правого бедра лежал железный нож во фрагментах (длина -7 см; табл. 44, II, 4).

Погребение 2. Части скелета, принадлежавшего, вероятно, женщине. In situ - кости правой руки, правая ключица, отдельные ребра и позвонки, фрагменты таза. Остальные кости отсутствуют. Положение вытянутое на спине головой на северо-запад. Правая рука согнута в локте, кисть, видимо, была уложена тазу.

Инвентарь. Правое запястье украшал бронзовый браслет (во фрагментах) со стилизованными змеиными головками на концах (табл. 43, II, 29). В районе шеи находились бусы. Низка I:

1) округлая из непрозрачного черного стекла в сочетании с полупрозрачным зеленовато-голубым (табл. 43, II, 2);

2) шаровидная из полупрозрачного синего стекла (табл. 43, II, 5);

3) шаровидная из полупрозрачного желтого и синего стекла в сочетании с глухим темно-синим (табл. 43, II, 13);

4) цилиндрические и вытянутые бочковидные из глухого стекла с синими, золотистыми, коричневыми и белыми витыми полосками - 6 шт. (табл. 43, II, 14,15);

5) округлые глазчатые из глухого стекла (синий, с белой обводкой орнамент на бежевом, красном и синем фоне) - 12 шт. (табл. 43, II, 4, 12, 16);

6) цилиндрическая пронизь из глухого красно-коричневого стекла (табл. 43, II, 10);

7) сильно ирризированные цилиндрические пронизи из полупрозрачного бесцветного стекла, возможно, с металлической прокладкой - 2 шт. (табл. 43, II, 11);

8) бочковидные и шаровидные из прозрачного бесцветного стекла с металлической прокладкой, одинарные, сдвоенные, из трех и четырех шариков - 20 шт. (табл. 43, II, 7, 8);

9) в форме параллелепипеда из глухого коричневого стекла - 2 шт. (табл. 43, II, 9);

10) фигурка скарабея (?) из глухого серовато-коричневого стекла (табл. 43, II, б);

11) бочковидная из глухого темно-голубого стекла (табл. 43, II, 3).

Низка II:

1) цилиндрические пронизи из прозрачного бесцветного стекла - 11 шт. (табл. 43, II, 17);

2) бочковидные и шаровидные из прозрачного бесцветного стекла с металлической прокладкой, одинарные, сдвоенные, из трех и четырех шариков - 31 шт.

(табл. 43, II, 18-20); 
3) округлые глазчатые из глухого стекла (синий с бежевым орнамент на бежевом и красном фоне) - 5 шт. (табл. 43, II, 21);

4) в форме параллелепипеда из глухого коричневого стекла - 7 шт. (табл. 43, II, 22);

5) коротко-цилиндрическая из голубого фаянса (табл. 43, II, 26);

6) мелкие округлые из непрозрачного стекла зеленого, серого и красного цвета, некоторые соединенные - 6 шт. (табл. 43, II, 23-25).

Кроме того, в отчете упоминаются "большие янтарные" (Сымонович, 1977. С. 25). Одна из сохранившихся представлена на табл. 43 (II, 1 ).

В коллекции представлены также железные фрагменты меча и кинжала (длина - 27 см; табл. 44, II, 5, б).

Могила 41 (табл. 44). Шурф 6.

Катакомба. Камни заклада были вывернуты при современных земляных работах, входная яма также нарушена. На месте сохранилась большая каменная плита, закрывавшая вход (глубина 1,50 м). Камера (2,00 x 1,50 х 2,04 м) ориентирована по линии С3 - ЮВ и расположена к северо-востоку от входа. Ее форма не установлена, так как в южной части стенки не прослежены. Обнаружены скелеты двоих погребенных.

Погребение 1. Ближайшее ко входу. Принадлежало взрослому человеку. Большинство костей - in situ. Отсутствуют: верхняя часть позвоночника, отдельные фаланги пальцев рук и ног, часть нижней челюсти. Левое плечо немного смещено. Положение вытянутое на спине головой на северо-запад. Руки чуть согнуты в локтях, кисти прижаты к бедрам. Ноги скрещены в голенях (правая лежит на левой).

Инвентарь. К северу от черепа находилась лепная сероглиняная кружка с округлой, свитой из трех жгутов ручкой (диаметр венчика - 9,5 см; табл. 44, II, 2). Несколько в стороне, ближе к входу, лежал лепной сосуд, почти цилиндрической формы, с горизонтальным валиком, проходящим на одной трети высоты (диаметр венчика - 11,2 см; табл. 44, II, 1).

По обеим сторонам валика и на венчике сосуд украшен зигзагообразным орнаментом (на венчике - с точечными вдавлениями). Поверхность сосуда лощеная коричневато-желтого цвета.

Погребение 2. Вероятно, сдвинуто при совершении последующего захоронения (погребение 1). Большая часть костей смещена. Не исключено, что in situ - бедра и обломок большой берцовой кости правой ноги. Скорее всего, положение было вытянутым на спине головой на северо-запад.

Инвентарь. У восточной стенки могилы, среди обломков ребер, обнаружены фрагменты железного предмета. 


\section{Описание ям на раскопе I}

Кроме могил, на раскопе I (табл. 19, II) было обнаружено несколько ям и скоплений керамики. Они связаны с могильником и, видимо, представляют собой объекты культового значения.

Яма 1 под восточной стенкой раскопа глубиной 1,0 м имела круглую в плане форму, достигая сверху диаметра 0,5 м и сужаясь к плоскому дну. Заполнение углистое, в южной части находились камни. Обнаружены фрагменты лепного и гончарного сосудов.

Яма 2 в центральной части раскопа имела овальную форму (1,30 x 1,40 x 1,0 м) и была вытянута по линии ССВ - ЮЮЗ. В северной части находились три лошадиных черепа, в южной части - кости ног лошади. Среди костей обнаружен фрагмент светлоглиняной амфоры.

Яма 3 в юго- восточной части раскопа представляла собой небольшую западину в материке (диаметр около 0,80 м; глубина - 0,90 м), связанную с развалом камней, который был вытянут по линии СВ - ЮЗ. В западине стояла лепная серо-коричневая миска с шероховатой поверхностью, изготовленная из глины с примесью песка (диаметр венчика - 12 см; табл. 19, I).

Яма 4, располагавшаяся к западу от ямы 3 , имела не вполне правильную круглую форму (диаметр - 1,30 м; глубина - 1,10 м) и почти отвесные стенки. Инвентаря не было.

В северной части раскопа на глубине 0,80 м обнаружено большое скопление обломков керамики, основная часть которых принадлежала лепному сосуду черно-коричневого цвета с прилощенной поверхностью. Это был большой плоскодонный горшок, возможно, хозяйственного назначения ( диаметр тулова -30 см) с отогнутым венчиком и плечиками, украшенными налепным валиком (Сымонович, 1977. Табл. XV, 9). 


\section{Заключение}

Полевые исследования 1976-77 гг. в с. Красный Маяк позволяют сделать ряд предварительных выводов.

1. Могильник, на котором проводились раскопки, принадлежит к числу позднескифских грунтовых некрополей Нижнего Днепра типа Золотой Балки и Николаевки. Объект, обозначенный Э.А. Сымоновичем как "курган" (табл. 7), вероятно, представляет собой каменную выкладку, никак не связанную с находившимися под ней могилами. Об этом свидетельствует, прежде всего, тот факт, что погребение 1 (катакомба) выходило за пределы предполагаемой окружности "кругана". Кроме того, оно расположено в северо-восточном секторе, свободном от камней, которые, возможно, были выброшены в процессе сооружения этой могилы. Об этом упоминает и сам исследователь (Сымонович, 1976. С. 6). Согласиться можно лишь с тем, что более компактная выкладка меньшего диаметра связана с погребением 3 (Сымонович, 1976. С. 6). Подобные конструкции над могилами и забутовка входных ям камнями весьма характерны для поздескифских катакомб. Однако это не имеет никакого отношения к сооружению "курганов из камней".

2. Так же, как в Золотой Балке и Николаевке, основной обряд погребения на могильнике - игумация. Однако в 1977 г. было обнаружено одно безурновое трупосожжение (могила 16). К сожалению, инвентарь этого захоронения не слишком выразителен и не позволяет достаточно точно определить его дату. Очевидно лишь, что оно относится к первым векам н.э.

3. Типы погребальных сооружений некрополя Красный Маяк также соответствуют классификации, разработанной для позднескифской культуры Нижнего Днепра (Гей, 1987). Наиболее характерны захоронения в катакомбах, имевших, в основном, Т-образную форму, с преобладанием северо-западной ориентации погребенных. Обнаружены также подбойные и простые грунтовые могилы.

4. Основные категории погребального инвентаря некрополя Красный Маяк из раскопок 1976-77 гг. вполне соответствуют поздескифской культуре Нижнего Днепра. Это лепная и гончарная керамика, краснолаковые сосуды, оружие, предметы конской упряжки, разнообразные украшения из бронзы и, конечно, многочисленные бусы.

Однако хронологические рамки бытования вещей в Красном Маяке шире, чем на других могильниках (Золотая Балка, Николаевка), и выходят за пределы I - начала II в.в. н. э. Возможно, наиболее ранней из всех раскопанных в 1976-77 гг. была могила 34, содержавшая в составе инвентаря бронзовую гладкопроволочную среднелатенскую фибулу с верхней тетивой и скрепой (табл. 36, IV, 5). Несмотря на целый ряд спорных моментов, наиболее вероятная дата этих фибул в Северном Причерноморье - конец II - I в. до н.э. (Амброз, 1966. С. 13, 19).

Финальную стадию функционирования могильника могут определять такие вещи, как фрагмент дужки лучковой фибулы с длинной фигурной обмоткой (могила 25; табл. 23, III, 6), провинциальные коленчатые фибулы (могила 30, погребение 1; табл. 27, II, 13), некоторые разновидности сильно профилированных фибул (могила 30, погребение 2; табл. 27, III, 11). Эти вещи относятся ко II - III вв. н.э. (Амброз, 1966, С. 28, 38, 51; Ettlinger, 1973. S. 30; typenliste, № 53; typentafel B, № 53).

Аналогии некоторым фибулам происходят из римских лагерей. Особо следует отметить уникальную для территории Северного Причерноморья фибулу с трапециевидной спинкой, украшенной полосками синей и красной эмали, и полукруглым щитком сверху (могила 30 , погребение 3; табл. 28, 1; Гей, 1993, цветная вклейка, фибула и фибула-брошь из могильника Красный Маяк). Подобные фибулы относятся к типу "английских" (Ettlinger, 1973. S. 29; typenliste, № 38, typentafel B, № 38).

Детальный анализ погребального обряда и инвентаря могильника Красный Маяк возможно будет провести только после публикации материалов из раскопок 1986-88 гг. 


\section{Литература}

Алексеева Е.М., 1975. Античные бусы Северного Причерноморья // САИ. Вып. Г1-12. M. $-114 \mathrm{c}$.

Алексеева Е.М., 1978. Античные бусы Северного Причерноморья // САИ. Вып. Г1-12. M. $-115 \mathrm{c}$.

Алексеева Е.М., 1982. Античные бусы Северного Причерноморья // САИ. Вып. Г1-12. M. $-104 \mathrm{c}$.

Амброз А.К., 1966. Фибулы юга европейской части СССР // САИ. Вып. Д1-30. М. - 113 с. Артамонов М.И., 1948. Скифское царство в Крыму // Вестник ЛГУ. №8. С. 56-78.

Вязьмитина М.И., 1972. Золотобалковский могильник. Киев. - 190 с.

Вязьмитина М.И., 1986. Городища Нижнего Днепра // Археология Украинской ССР. Т. 2. г. Киев. С. 223-240.

Гей О.А., 1987. Погребальный обряд поздних скифов на Нижнем Днепре // СА. №3. С. 53-67.

Гей О.А., 1993. Черняховская культура. Происхождение и этнический состав // Славяне и их соседи в конце I тысячелетия до н.э. - первой половине I тысячелетия н.э. Археология СССР. Москва. С. 162-170.

Гошкевич В.И., 1913. Древние городища по берегам низового Днепра // ИАК. Вып. 47. C. 117-145.

Граков Б.Н., 1954. Каменское городище на Днепре // МИА. № 36. - 240 с.

Дашевская О.Д., 1989. Поздние скифы (III в. до н.э. - III в. н.э.) // Степи европейской части СССР в скифо-сарматское время. Археология СССР. Москва. С. 125-145.

Елагина Н.Г., 1958. Население Нижнего Поднепровья во II в. до н.э. - IV в. н.э. // Вестник МГУ. № 4. C. $45-58$.

Погребова Н.Н., 1958. Позднескифские городища на Нижнем Днепре // МИА. № 64. C. 103-247.

Симоненко О.В., Сікоза Д.М., Дзнеладзе О.С., 2015. Пізньоскіфський могильник Червоный Маяк. Херсон. -154 с.

Симоненко А.В., 2016. О происхождении позднескифской культуры Нижнего Днепра // Стародавнэ Причерноморяя. Вип. ХІ. Одесса. С. 476-483.

Сымонович Э.А., 1969. Раскопки Николаевского могильника на Нижнем Днепре // КСИА. Вып. 119. С. 74-80.

Сымонович Э.А., 1971. Культура поздних скифов и Черняховские памятники в Нижнем Поднепровье // МИА. № 177. С. 63-74.

Сымонович Э.А., 1976. Отчет о работах Черняховской экспедиции ИА АН СССР в 1976 г. Работы в Херсонской обл. Архив ИА РАН. -20 с.

Сымонович Э.А., 1977. Отчет о раскопах Черняховской экспедиции ИА АН СССР на Украине в 1977 г. Работы в Херсонской обл. Архив ИА РАН. - 32 с.

Сымонович Э.А., Гей О.А., 1978. Черняховская экспедиция на Украине // АО 1977 г. С. 388-389.

Чирков А.П., 1867. Краткий очерк городищ, находящихся по Днепру и его лиману // ЗООИД. Т. VI. C. $546-550$.

Шульц П.Н., 1971. Позднескифская культура и ее варианты на Днепре и в Крыму // МИА.№ 177. С. 127-143.

Щукин М.Б., 1970. К истории Нижнего Поднепровья в первые века нашей эры // АСГЭ. Вып. 12. С. 54-67.

Щукин М.Б., 1979. К предыстории черняховской культуры. Тринадцать секвенций // АСГЭ. Вып. 20. С. 66-89.

Ястребов В.Н., 1894. Опыт топографического обозрения древностей Херсонской губернии // ЗООИД. Т. ХVII. С. 63-176.

Ebert M., 1913. Ausgrabungen bei dem "Gorodok Nikolajewka" am Dnjepr, Gouv. Cherson // PZ. Bd. V. H. 1-2. Leipzig. S. 80-113.

Ettlinger E., 1973. Die romischen Fibeln in der Schweiz. Bern. Francke. - 197s. 


\section{Список сокращений}

АО - Археологические открытия

АСГЭ - Археологический сборник Государственного Эрмитажа

ГИМ - Государственный исторический музей

ЗООИД - Записки Одесского общества истории и древностей

ИА АН СССР - Институт археологии Академии наук СССР

ИАК - Известия Императорской Археологической комиссии

КСИА - Краткие сообщения Института археологии

ЛГУ - Ленинградский государственный университет

МГУ - Московский государственный университет

МИА - Материалы и исследования по археологии СССР

РАН - Российская академия наук

СА - Советская археология

САИ - Свод археологических источников

PZ - Praehistorische Zeitschrift 


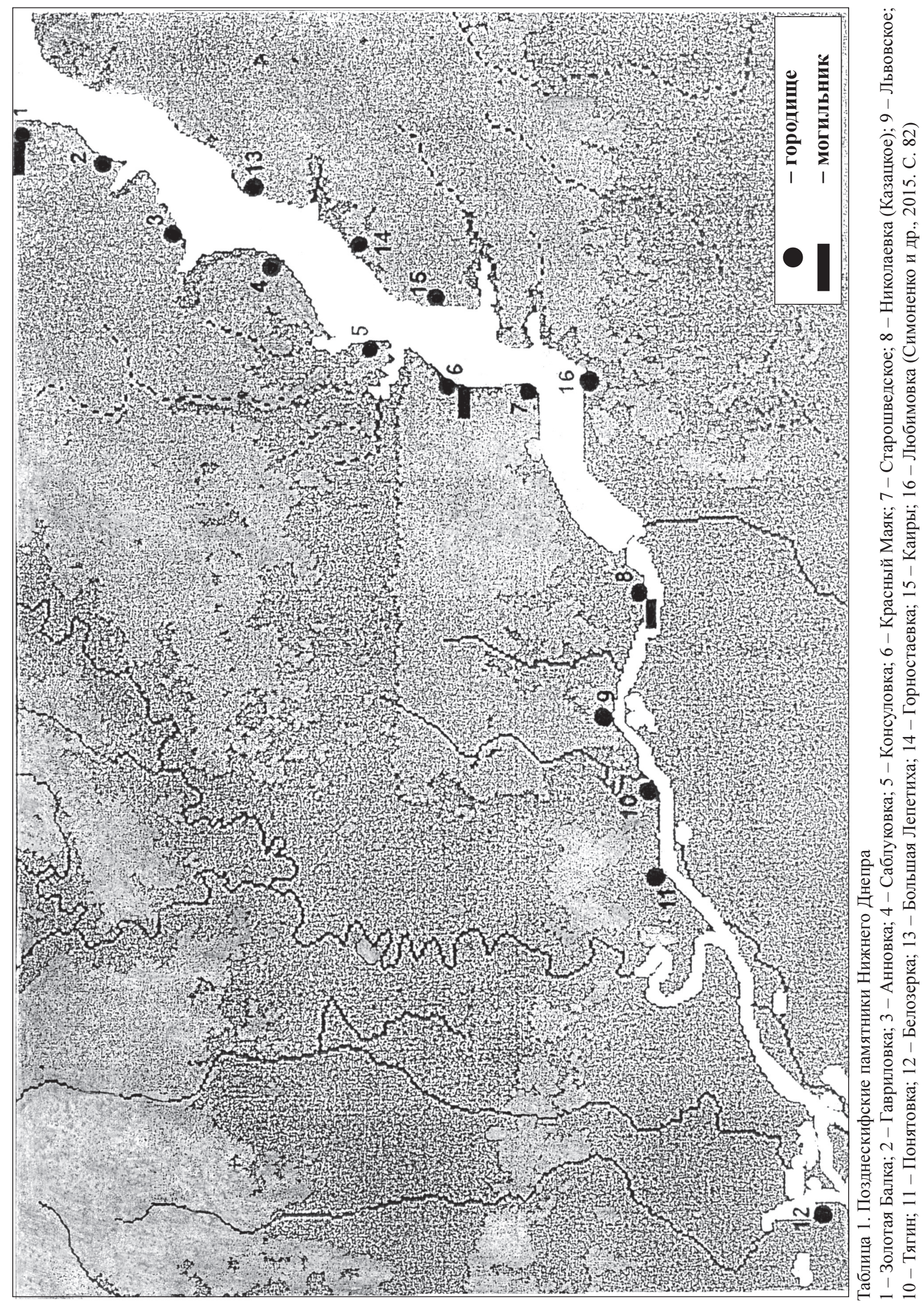




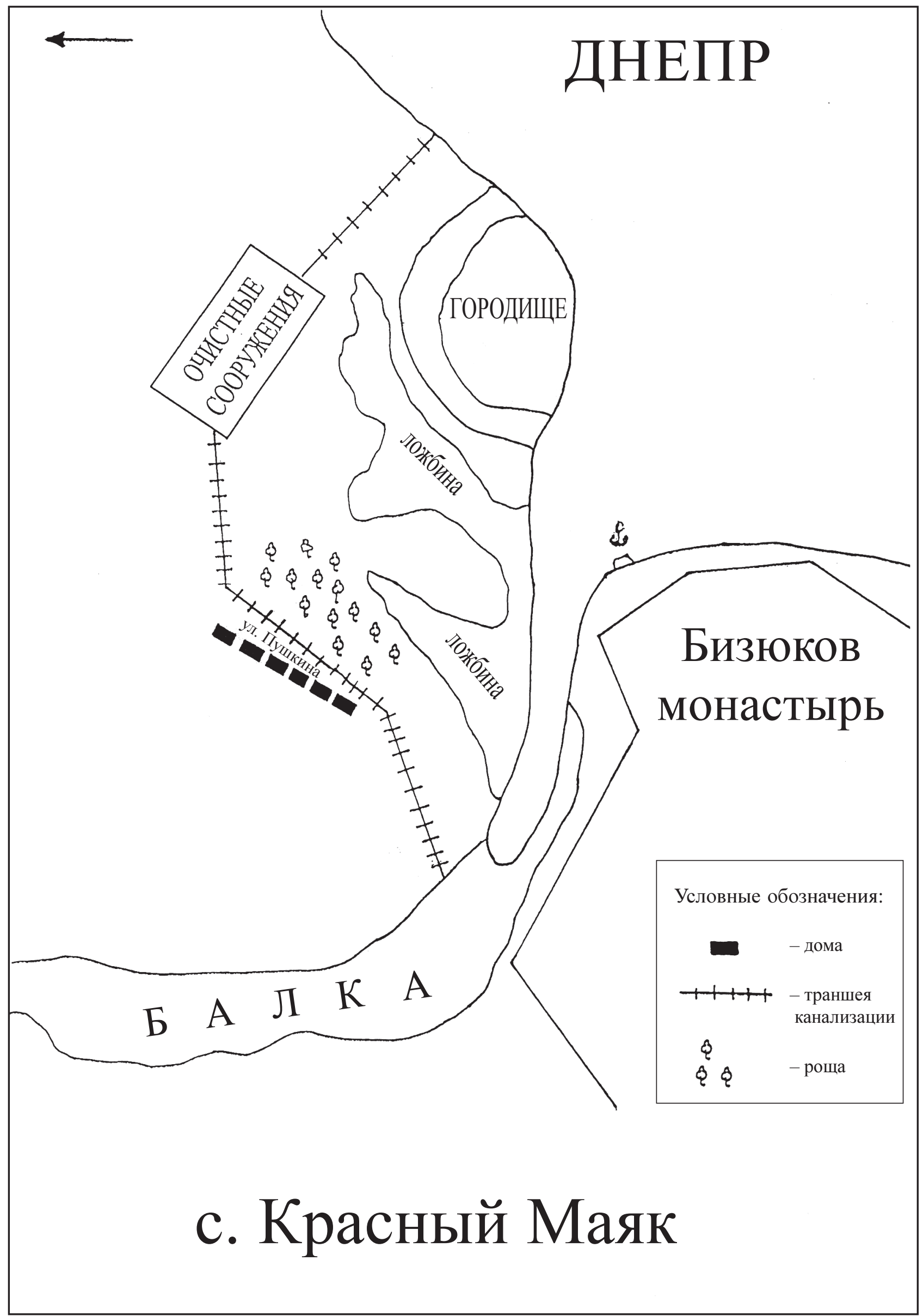

Таблица 2. Схема расположения нового посёлка, на территории которого проводились раскопки в 1976-77 гг. (по материалам Э.А. Сымоновича) 


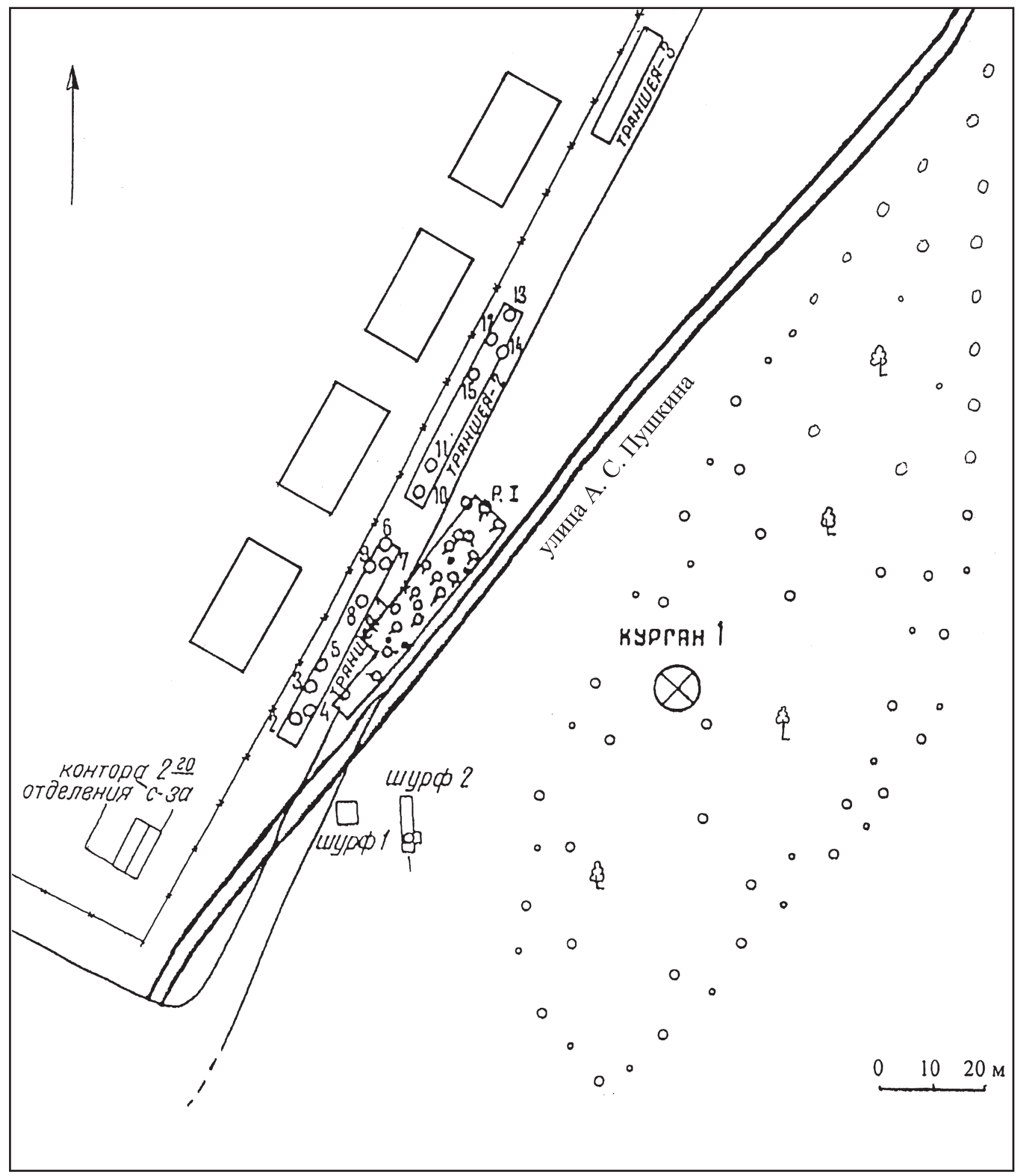

Таблица 3. Схема расположения объектов, раскопанных на ул. Пушкина (по материалам Э.А. Сымоновича) 

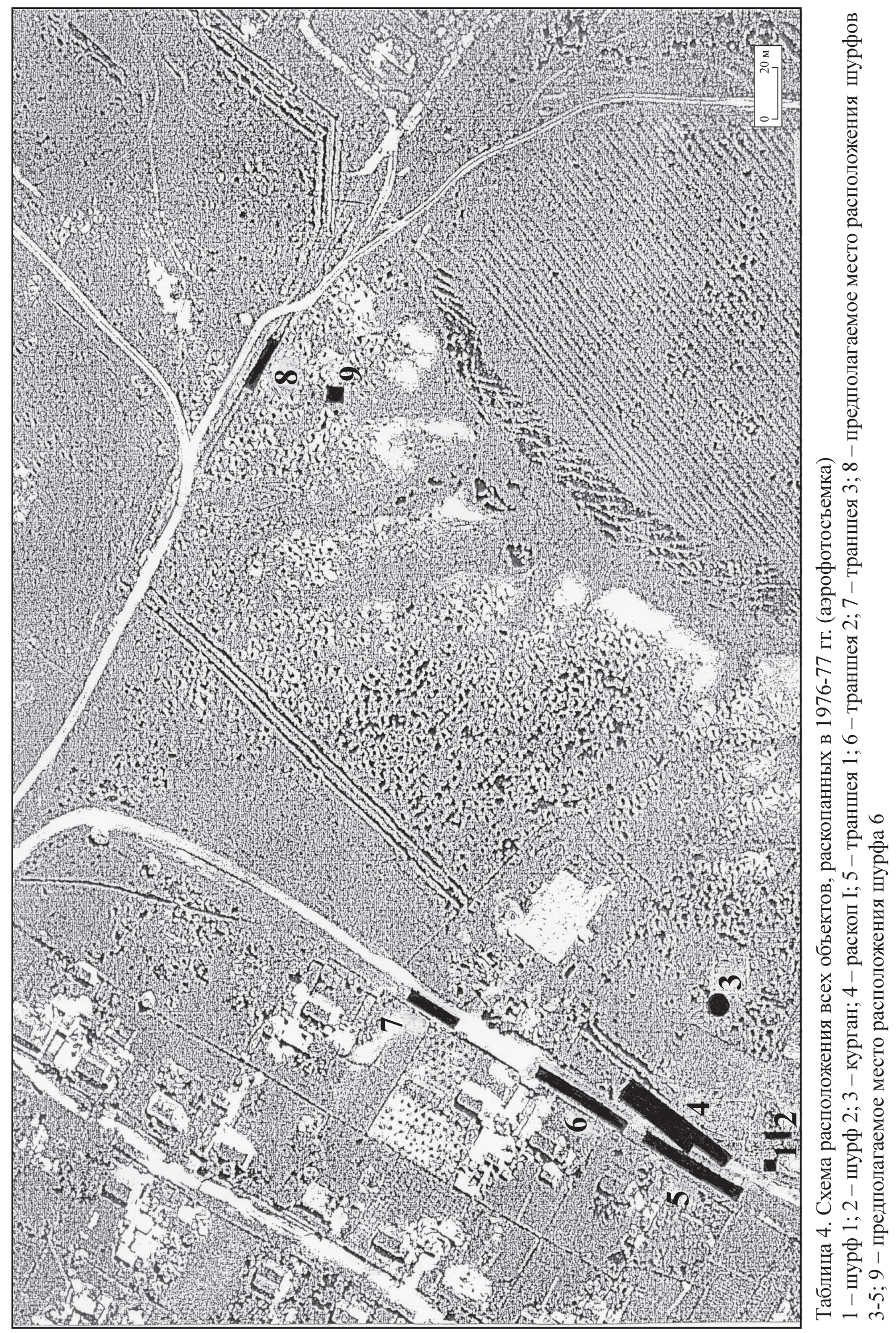

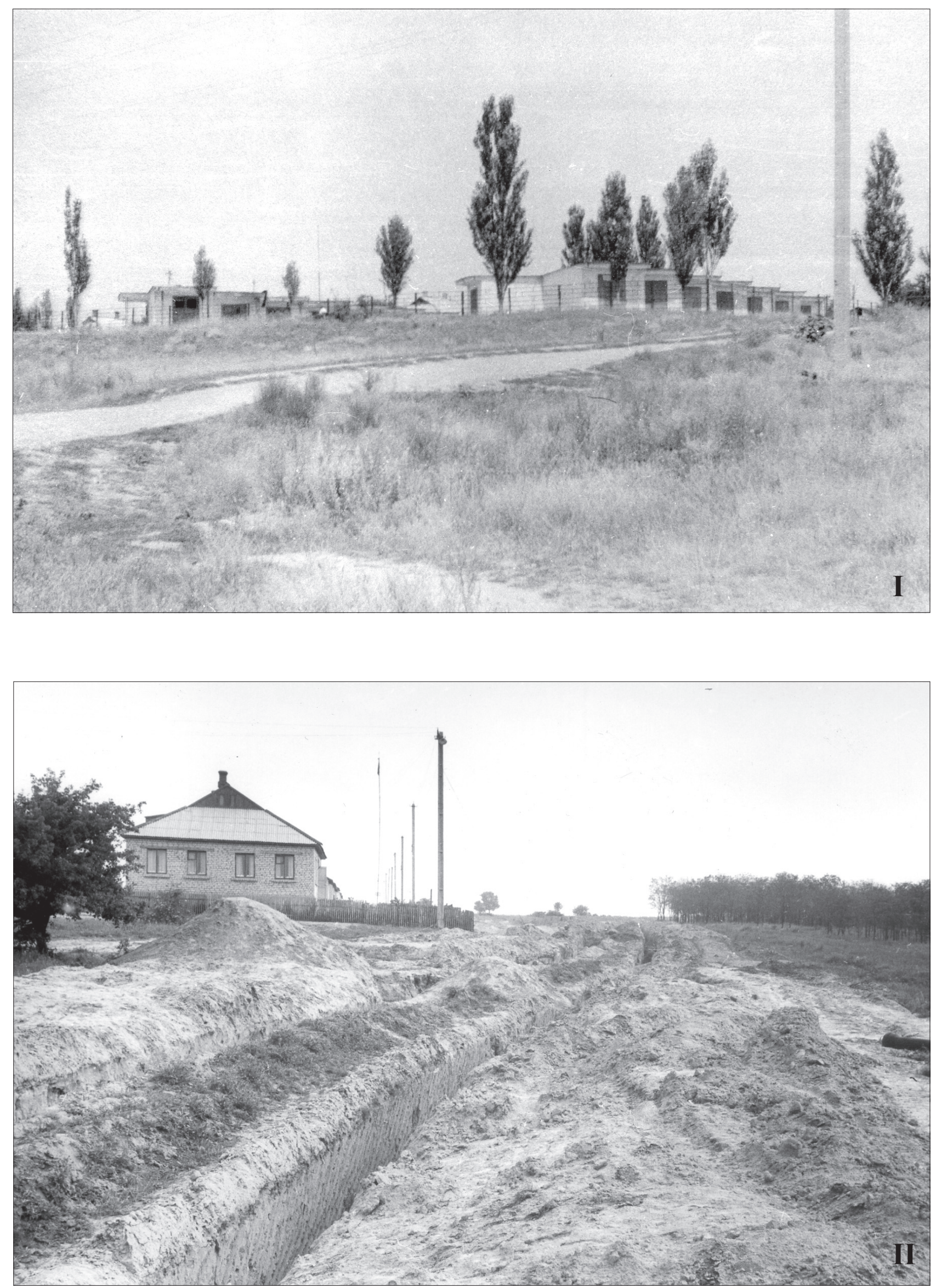

Таблица 5. Новая часть посёлка Красный Маяк

I - лагерь экспедиции; II - канализационная траншея на улице Пушкина 

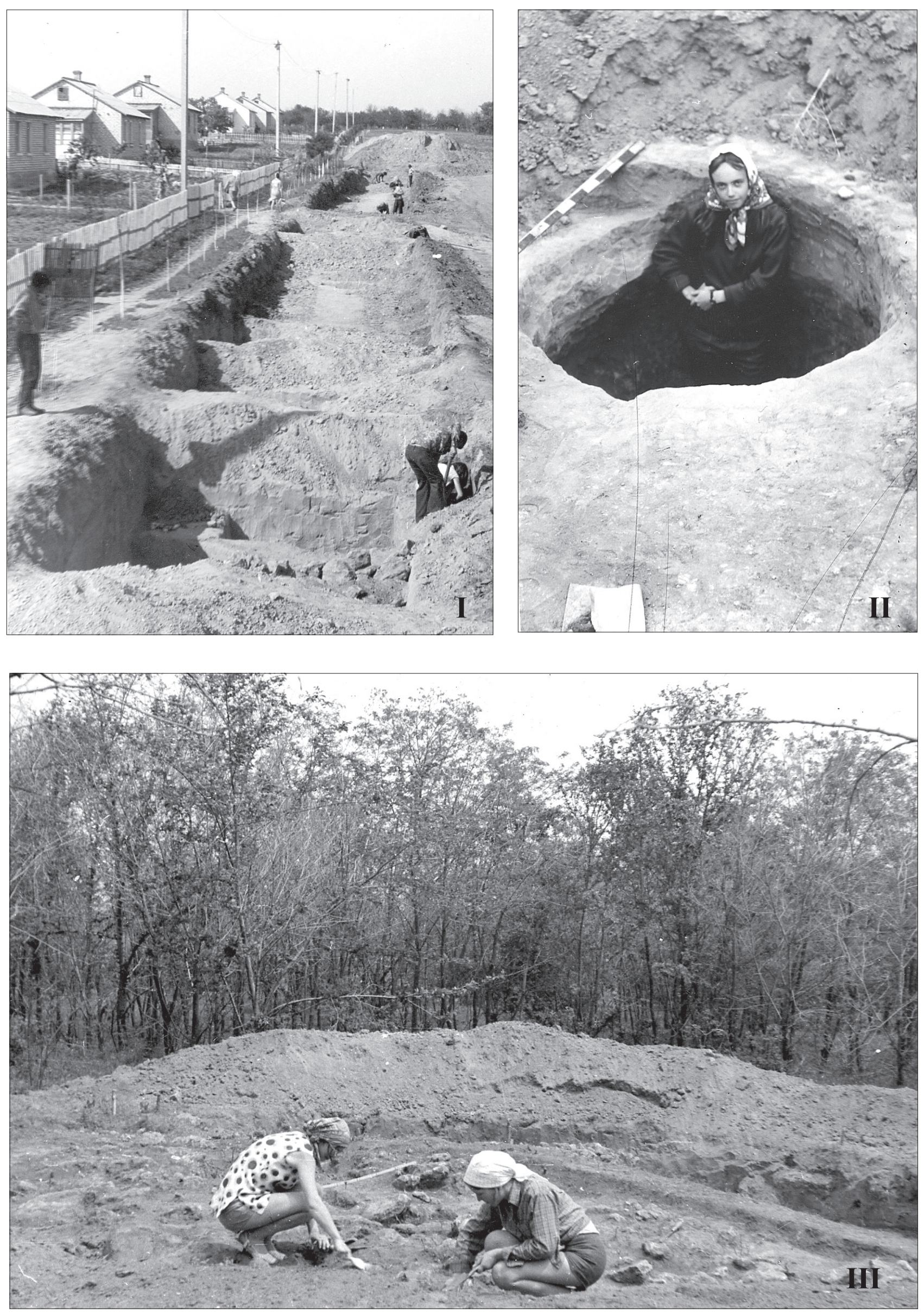

Таблица 6. Рабочие моменты на раскопах

I, III - 1976 г. (траншеи, заложенные с помощью бульдозера; «курган»); II - 1977 г. (раскоп I) 

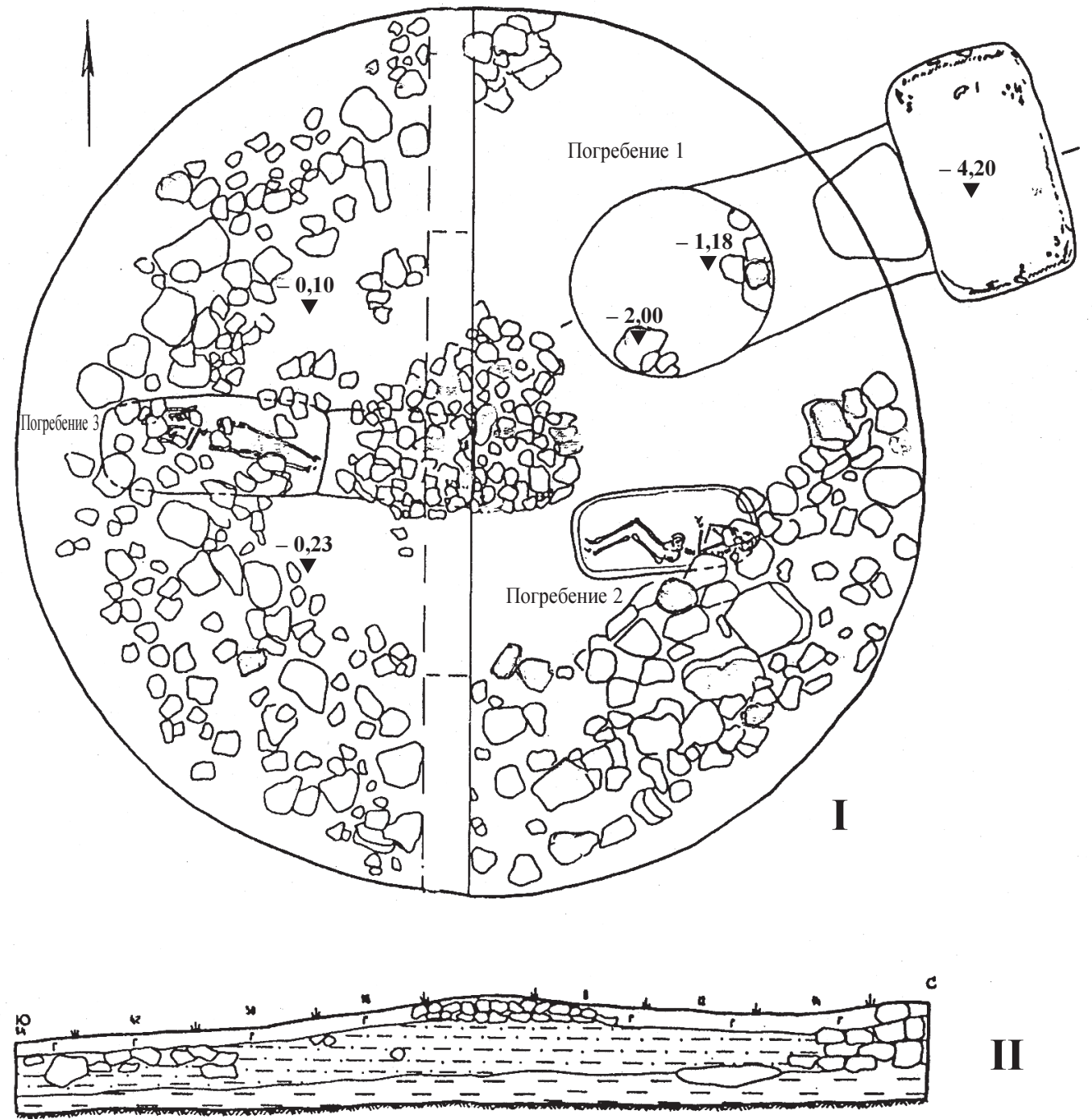

Условные обозначения:

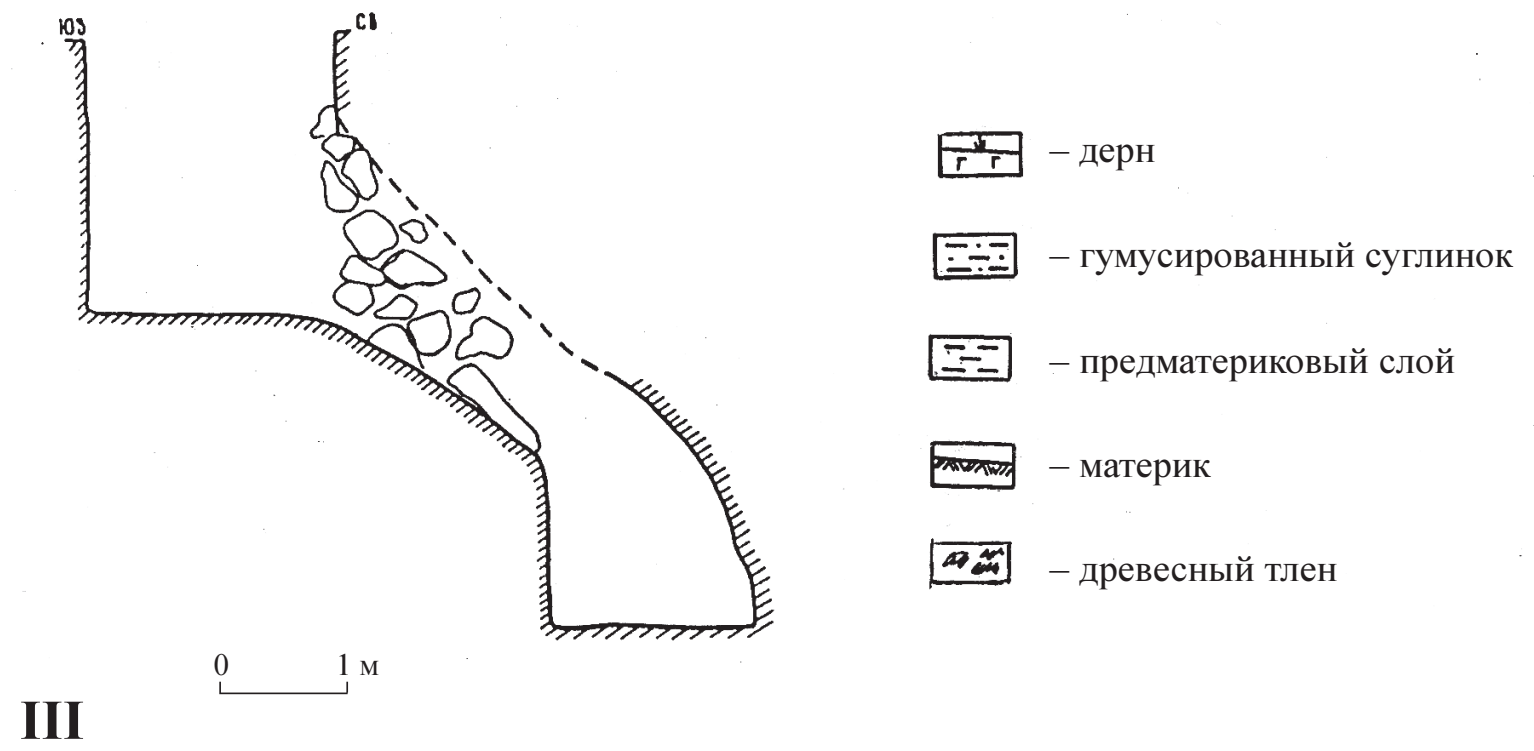

Таблица 7. Курган 1

I - план: 1 - оболомки черепа, 2 - кружка, 3 - стрелы, 4 - обломки меча, 5 - кости живоных; II - разрез; III - разрез погребения 1 


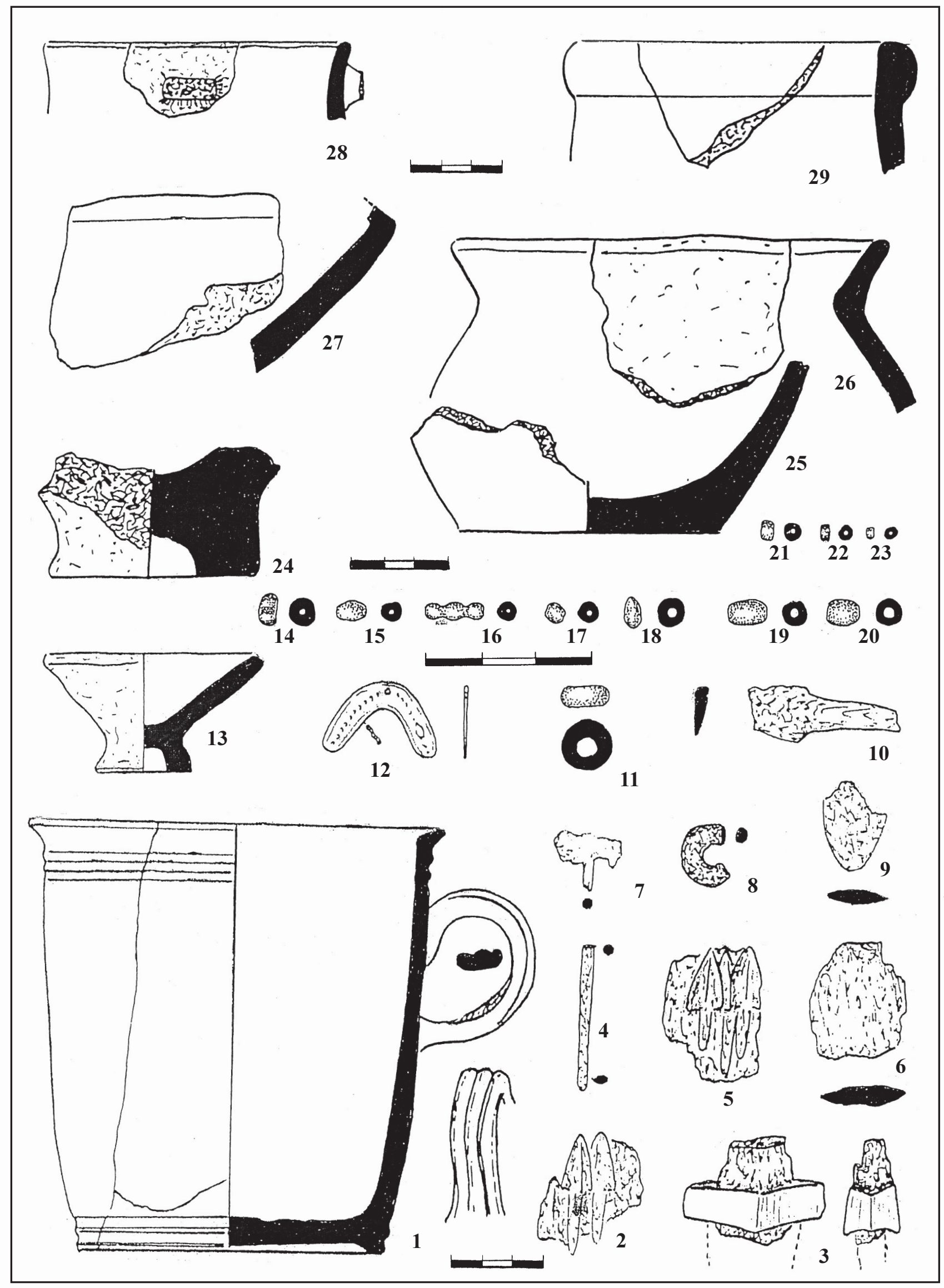

Таблица 8. Инвентарь кургана 1

1-11, 25, 26, 28 - погребение 1; 12-20 - погребение 2; 21-23 - погребение 3; 24, 27, 28, 29 - находки из слоя; 1, 13, 24-29 - керамика; 2-10 - железо; 11 - янтарь; 12 - бронза; 14-20 - стекло; 21-23 - фаянс; 1-13, 24-29 - рисунки Э.А. Сымоновича 


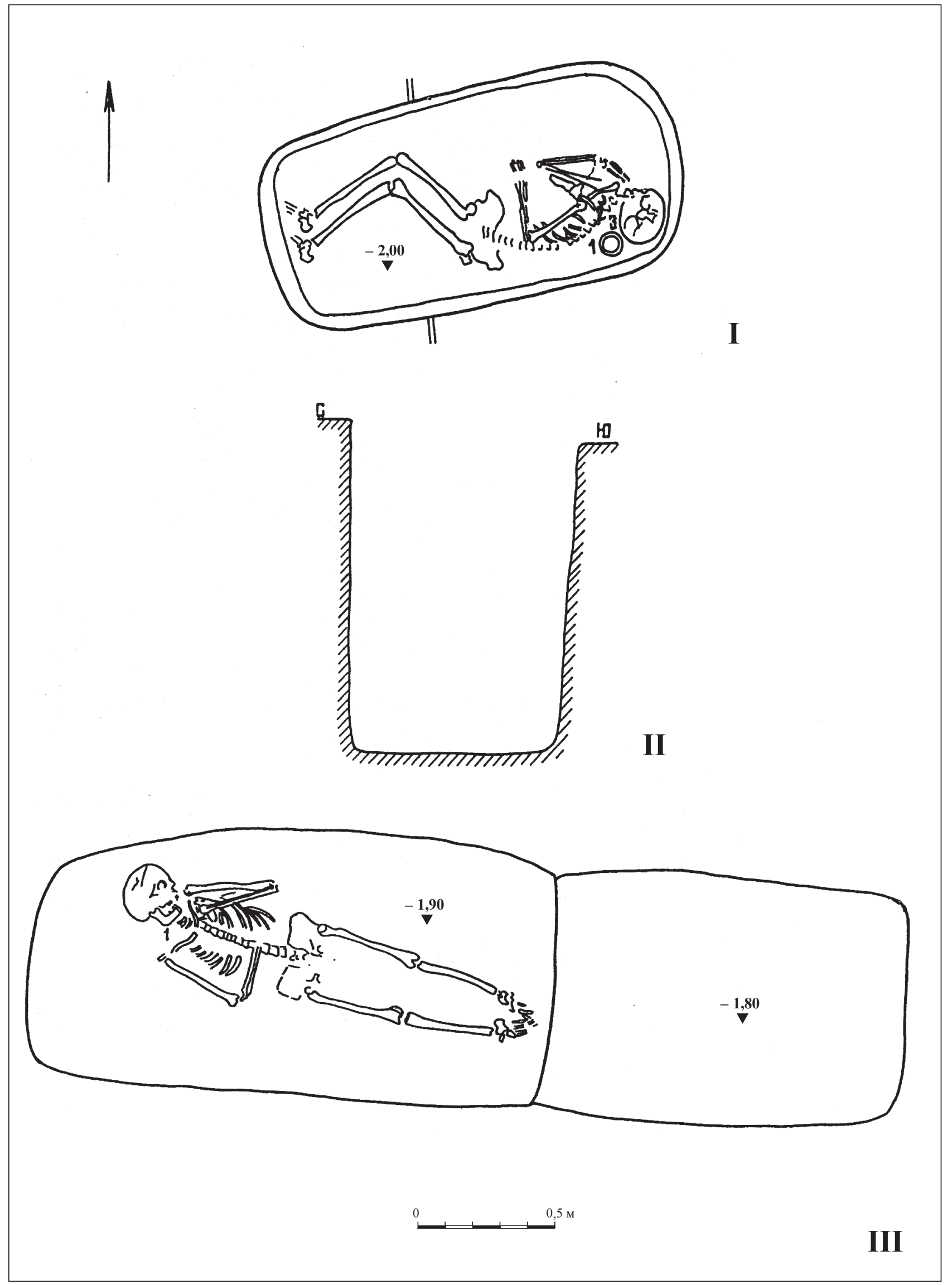

Таблица 9. Погребение 2 и 3 кургана 1

I - план погребения 2: 1 - сосуд, 2 - лунница, 3 - бусы; II - разрез погребения 2; III - план погребения 3: 1 - бисер 


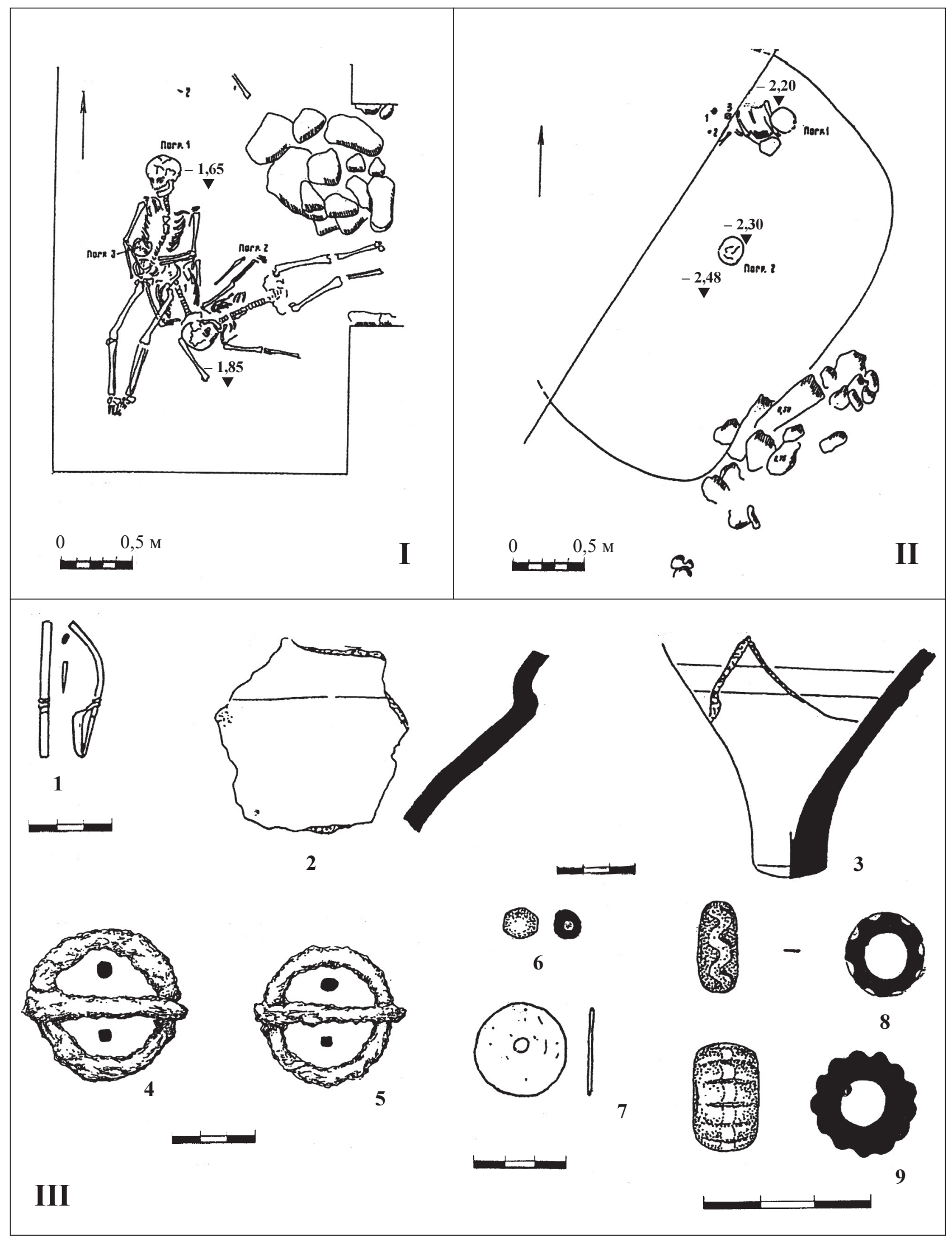

Таблица 10. Могилы 1,2

I - план могилы 1: 1 - фибула, 2 - раковина; II - план могилы 2: 1,3 - пряжки; 2 - бляшка; III инвентарь: 1, 2 - могила 1; 3 - могила 2, заполнение; 4-9 - могила 2, погребение $1 ; 1,7$ - бронза; 2, 3 керамика; 4, 5 - железо; 6, 8, 9 - стекло; 1-3, 7 - рисунки Э.А. Сымоновича 


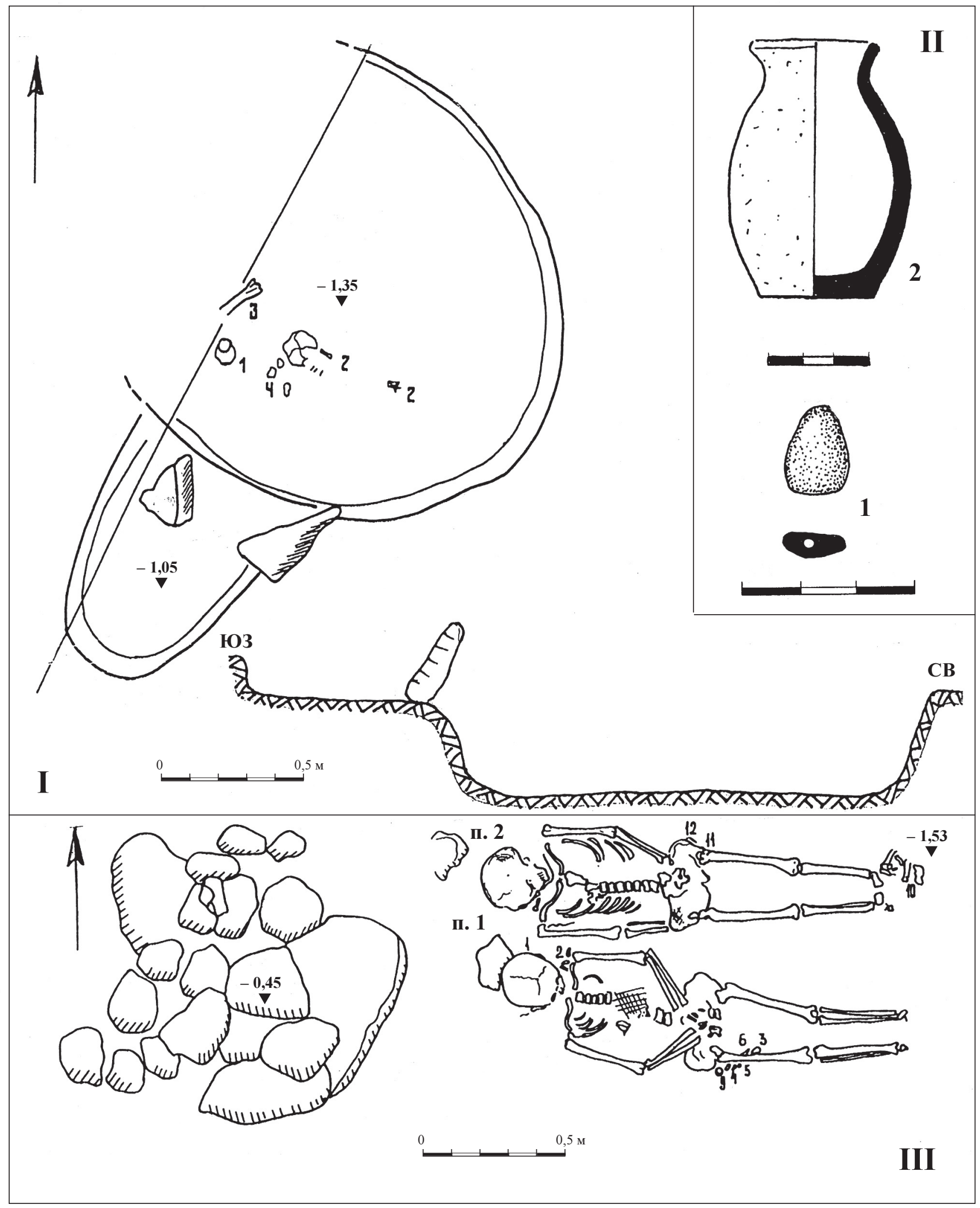

Таблица 11. Могилы 3, 4

I - план и разрез могилы 3: 1 - сосуд; 2 - бусы; 3 - кости лошади; 4 - кости животных; II - инвентарь могилы 3: 1 - янтарная бусина; 2 - лепной горшок (рисунок Э. А. Сымоновича); III - план могилы 4: 1 - серьги 1; 2, 4, 8 - бусы; 3 - кольцо; 5, 6 - колокольчики; 7 - фибула; 9 - пряслице; 10 - кости животных; 11 - пряжка; 12 - нож 
$(0$.<smiles>C1=CC=CC=CC=CC=1</smiles>
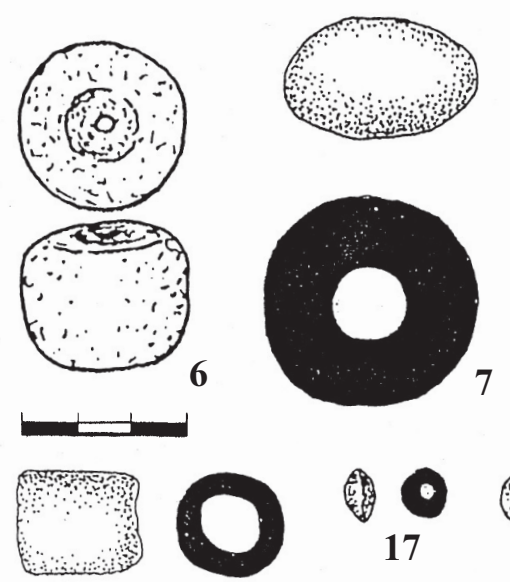

16

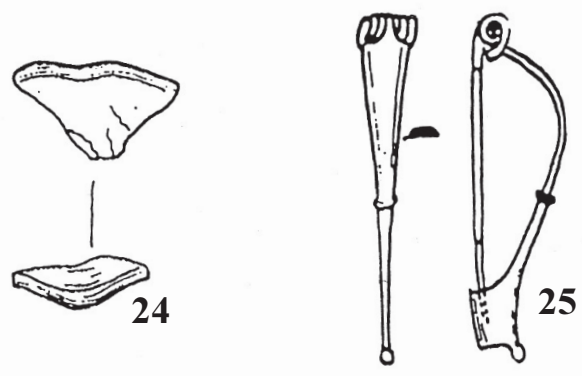

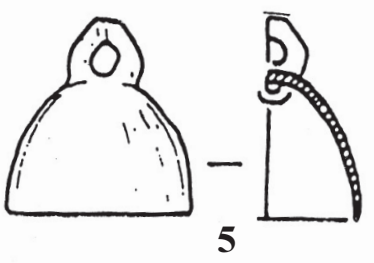

4
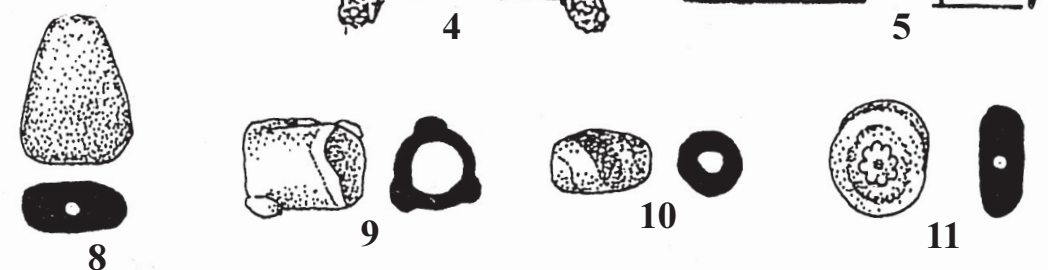

P.

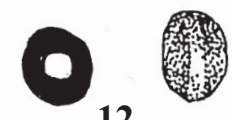

(0)

13

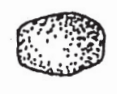

(8) 0
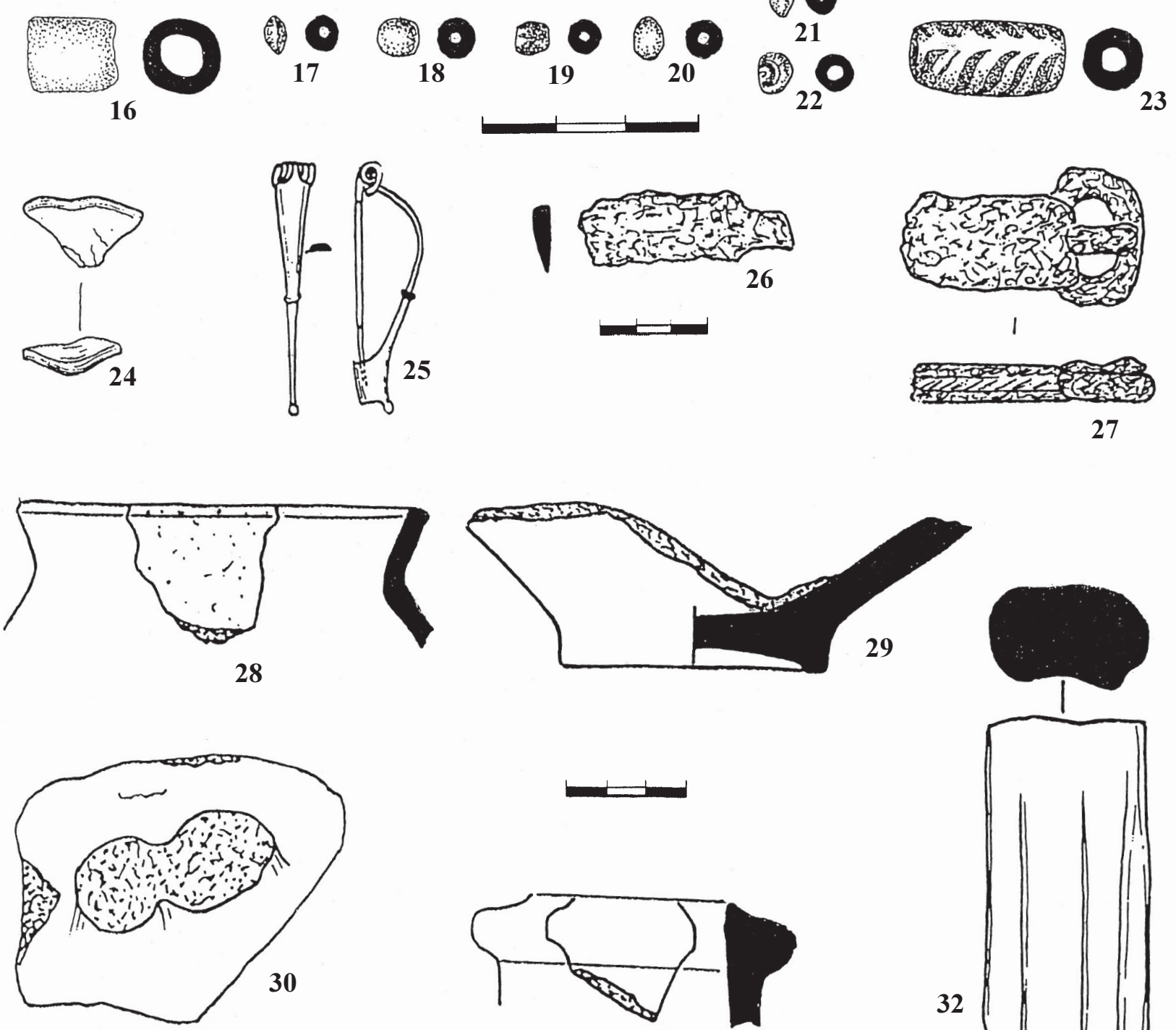

27

31

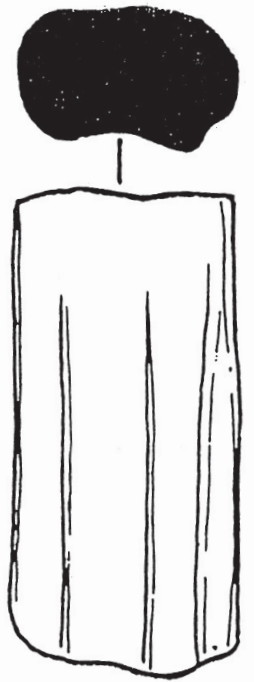

Таблица 12. Инвентарь могилы 4

1-22 - погребение 1; 23, 24, 26-30 - заполнение; 25-27 - погребение 2; 1, 2, 4, 5, 9, 25 - бронза; 3, 26, 27 - железо; 6 - кварцит; 7 - халцедон; 8 - янтарь; 10-15, 17-20, 22 - стекло; 16 - меловая порода; 21 фаянс (?); 26-30 - керамика; 1-6, 24-32 - рисунки Э.А. Сымоновича 


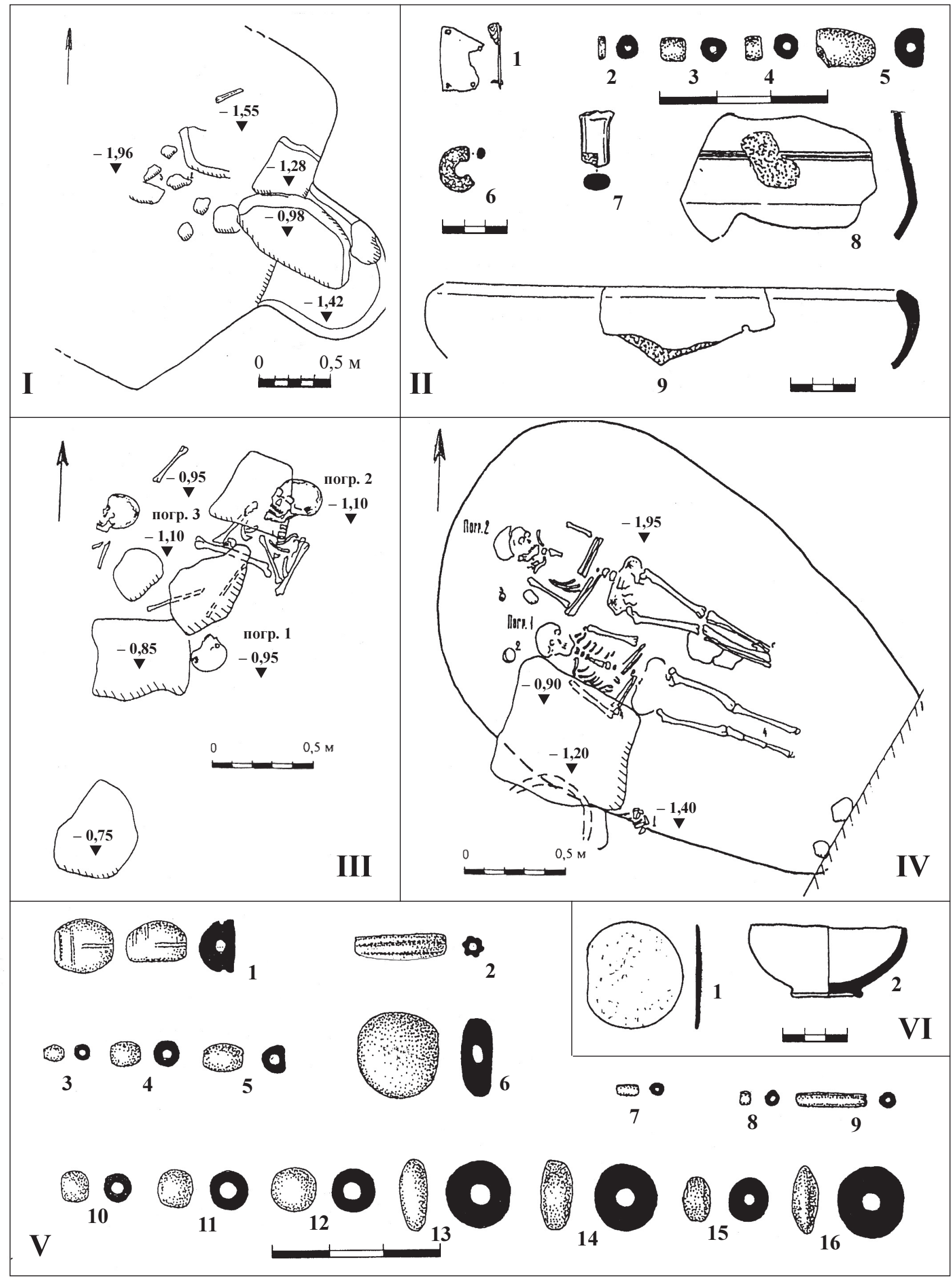

Таблица 13. Могилы 5-7

I - план могилы 5: 1 - кость лошади, 2 - обломок пластины, 3 - бусы; II - инвентарь могилы 5: 1 бронза, 2-4 - гагат, 5 - янтарь,6 - железо, 7-9 - керамика; III - план могилы 6; IV - план могилы 7: 1 зубы лошади, 2 - миска, 3 - зеркало, 4 - бусы; V - бусы и подвески из могил 6 и 7: 1 - могила 6; 2-16 могила 7; VI - инвентарь могилы 7: 1 - бронза, 2 - керамика; II, 1, 6-9; VI - рисунки Э.А. Сымоновича 

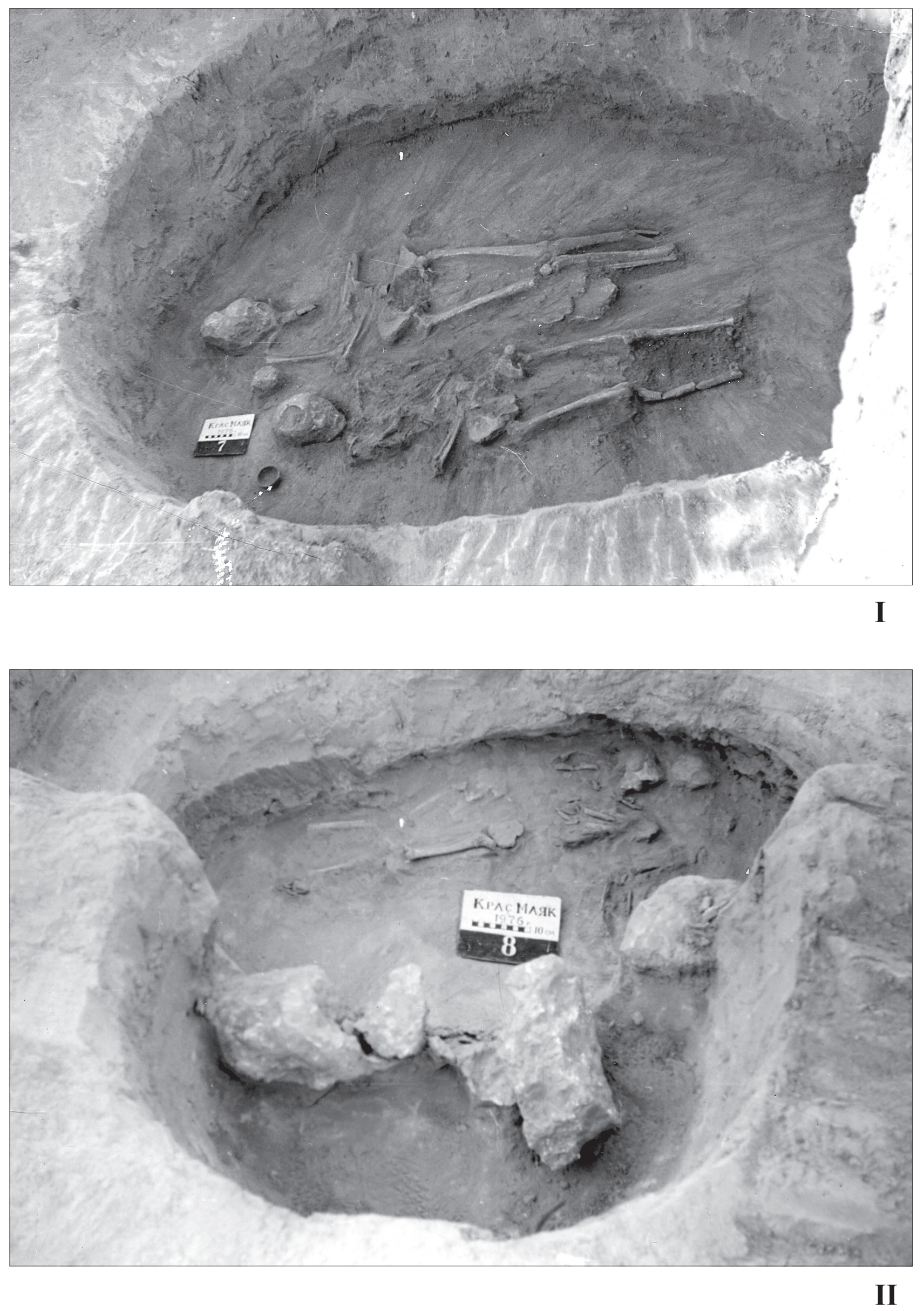

Таблица 14. Могилы 7 и 8

I - могила 7; II - могила 8 


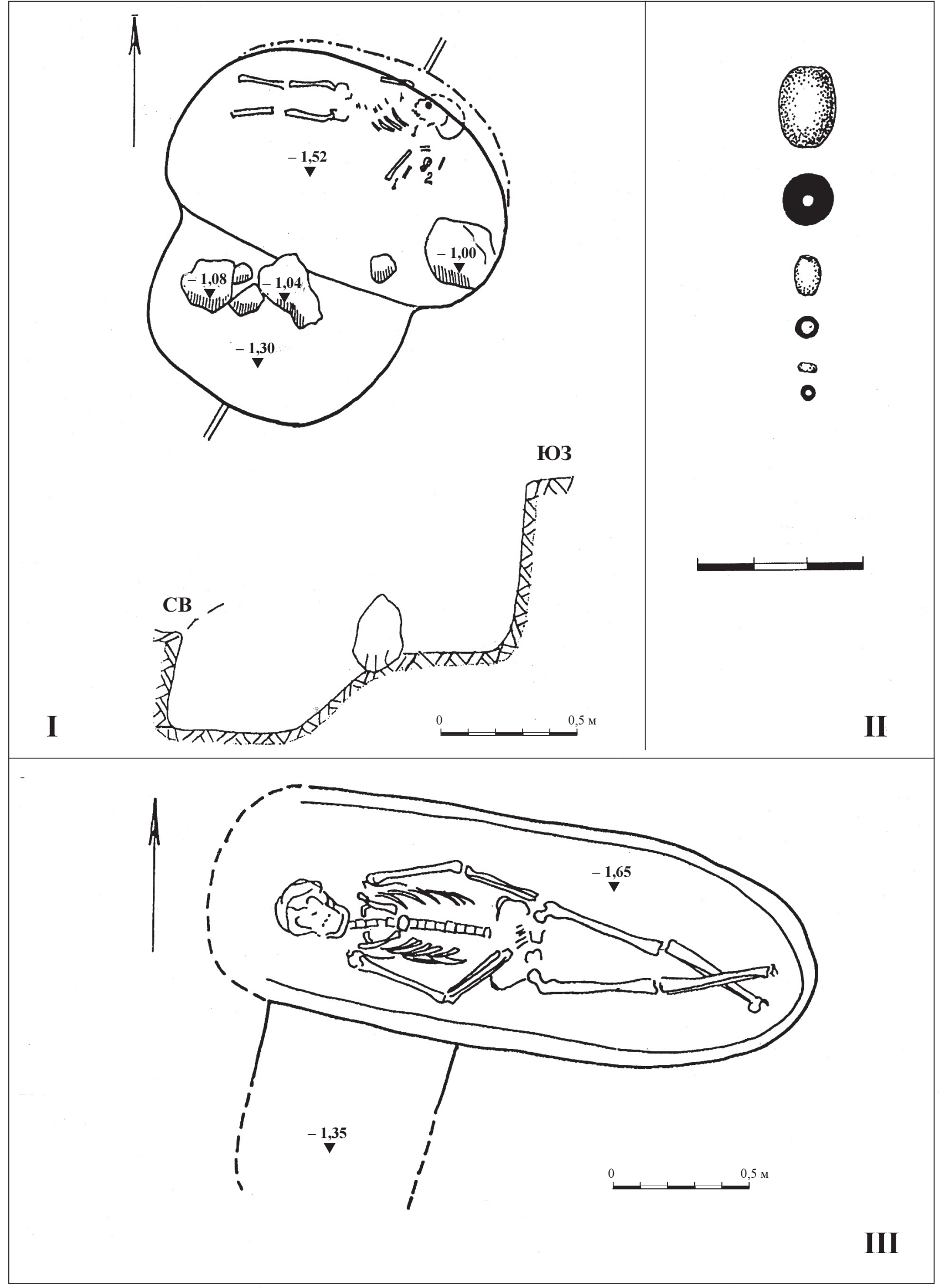

Таблица 15. Могилы 8 и 9

I - план и разрез могилы 8: 1 - бусы, 2 - астрагал барана; II - бусы из могилы 8; III - план могилы 9 


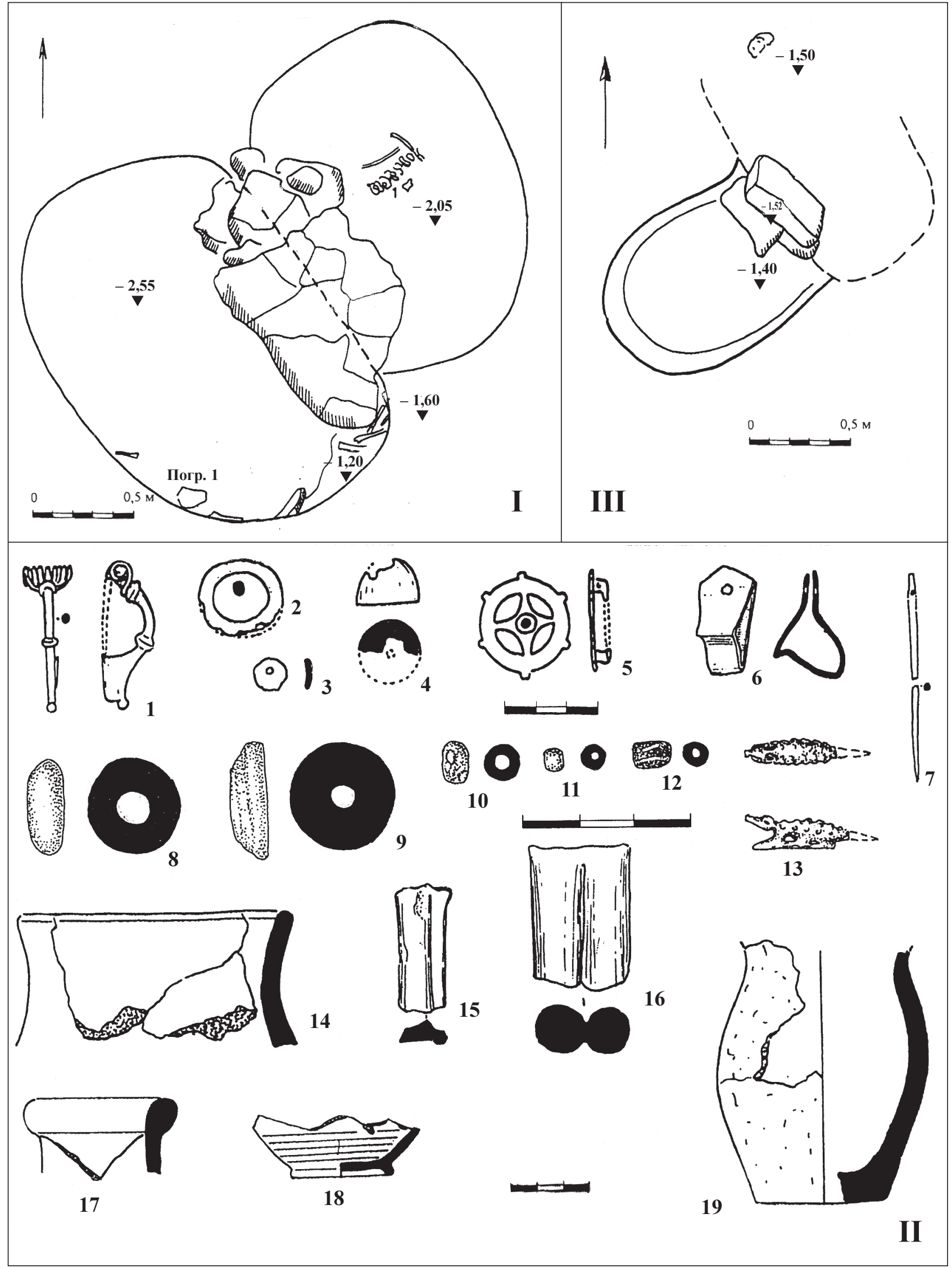

Таблица 16. Могилы 10 и 13

I - план могилы 10: 1 - кости лошади; II - инвентарь могилы 10: 1, 2, 4-7 - бронза; 3 - раковина; 8 - свинец; 9-12 - стекло; 13 - фаянс; 14-19 - керамика; III - план могилы 13; II, 1-7, 14-19 рисунки Э.А. Сымоновича 


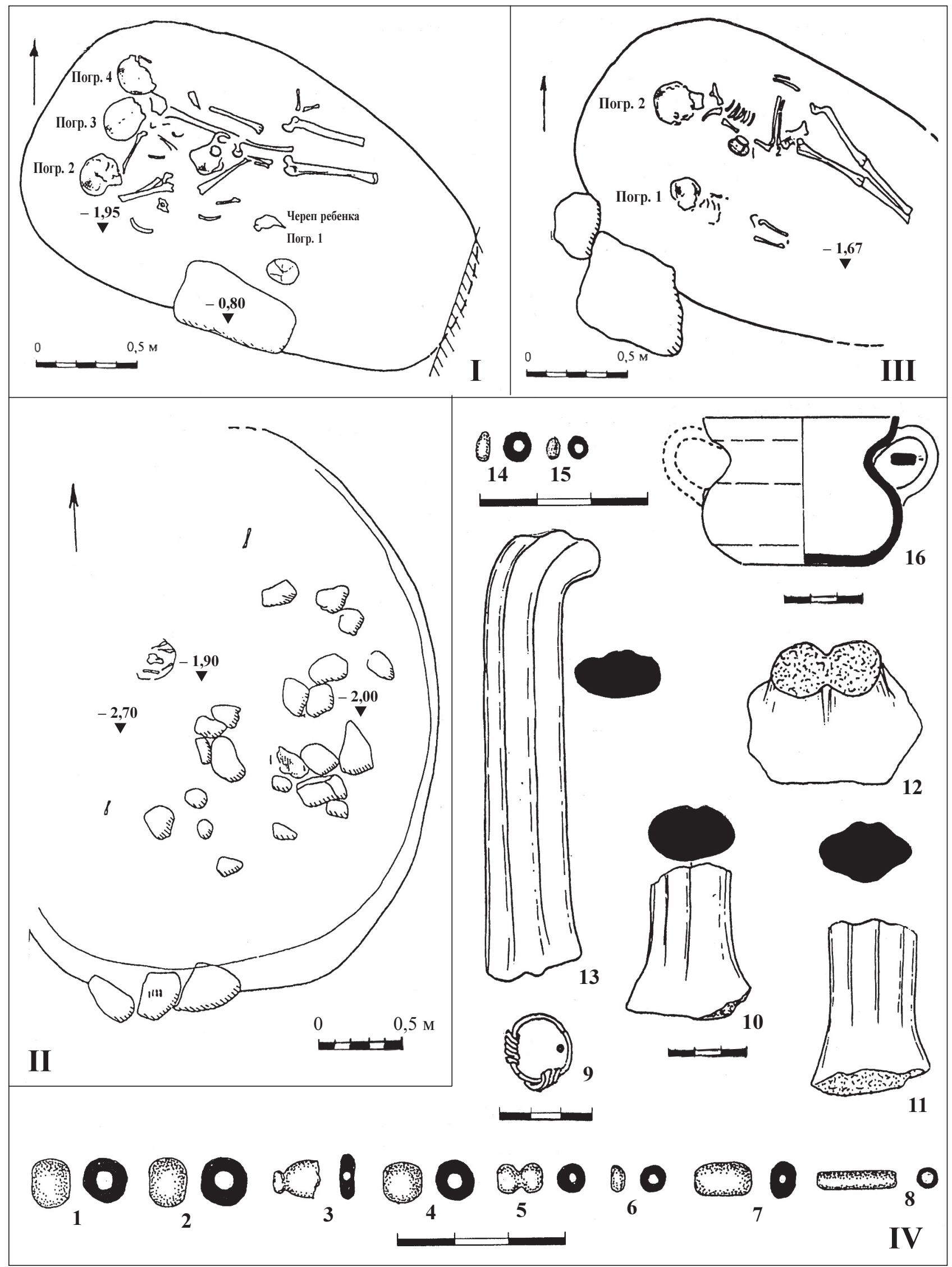

Таблица 17. Могилы 11, 12, 14

I - план могилы 11; II - план могилы 12; III - план могилы 14; IV - инвентарь: 1-9 - могила 11; 10-13 - могила 12; 14-16 - могила 14; 1-8, 14, 15 - стекло; 9 - бронза; 10-13, 16 - керамика; IV, 9-13, 16 - рисунки Э.А. Сымоновича 


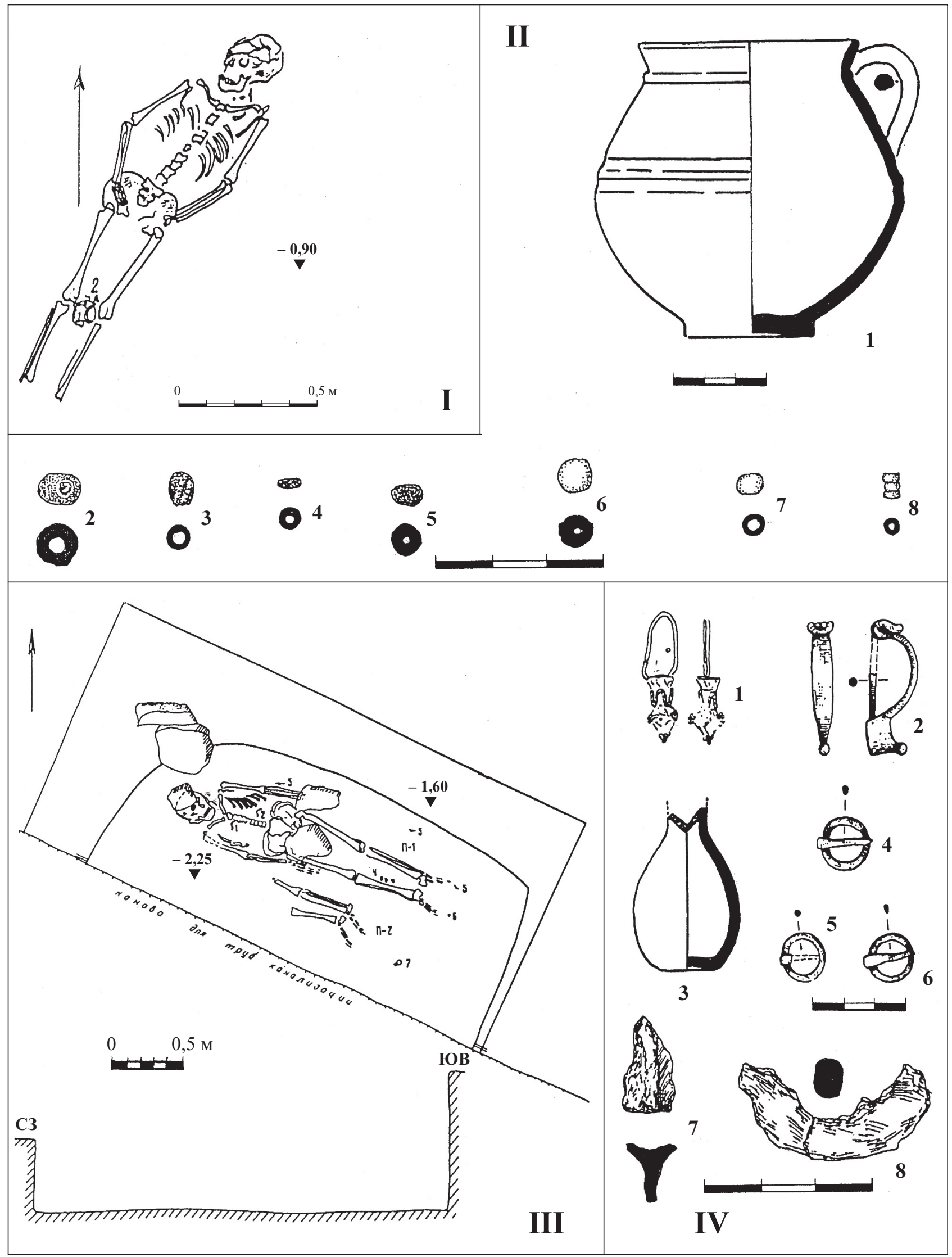

Таблица 18. Могилы 15 и 17

I - план могилы 15: 1 - бусы, 2 - кружка; II - инвентарь могилы 15: 1 - керамика; 2-8 - бусы; III - план и разрез могилы 17: 1-2 - фибулы; 3 - обломок железной пряжки; 4 - три бронзовые пряжки; 5 - наконечник стрелы; 6 - обломок железного предмета; 7 - сосуд; IV - инвентарь могилы 17: 1 - золото; 2, 4-6 - бронза; 3 - керамика (рисунки Э.А. Сымоновича); 7, 8 - железо 


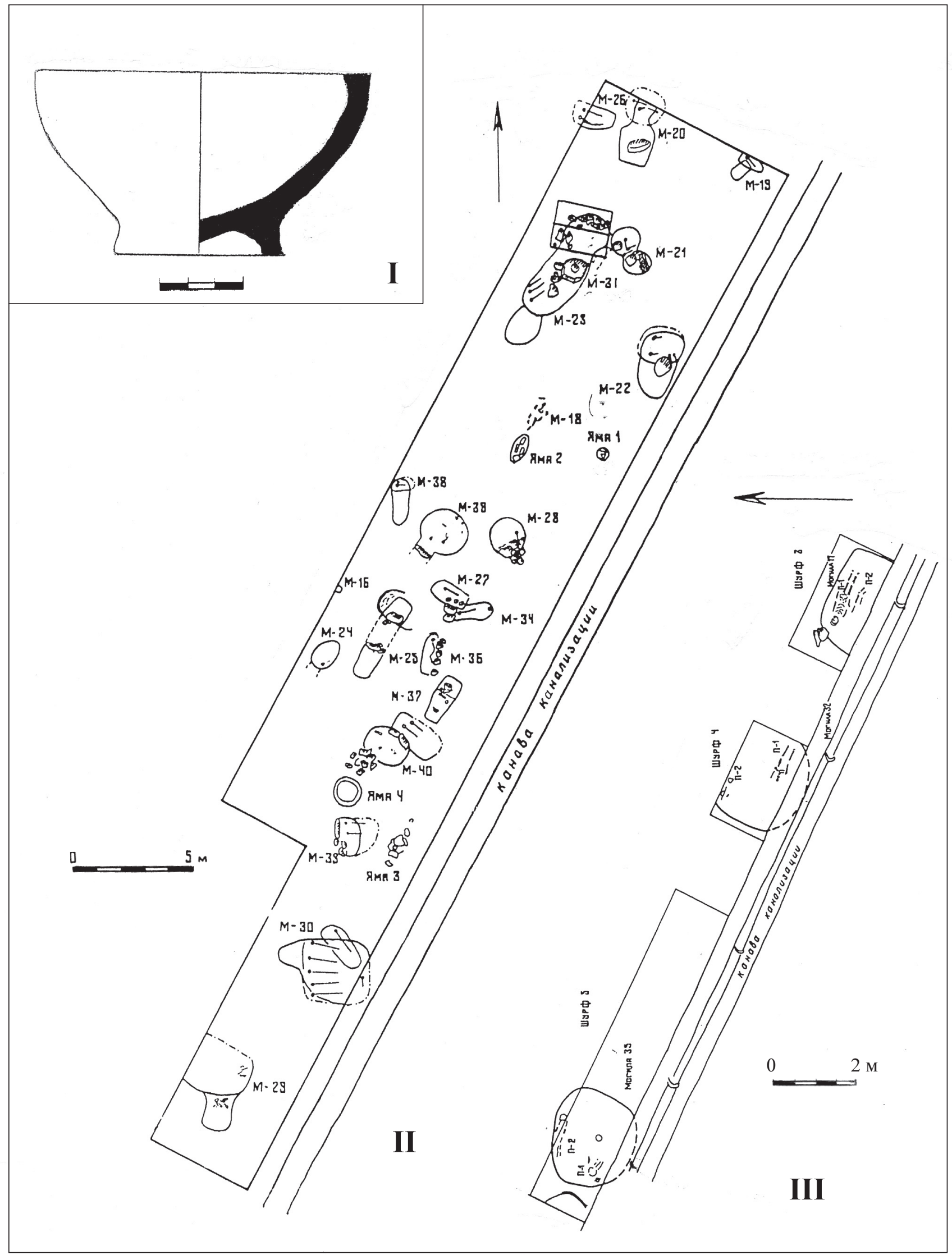

Таблица 19. Раскопки 1977 г.

I - миска из ямы 3; II - раскоп I; III - шурфы 3-5; чертежи и рисунки Э.А. Сымоновича 


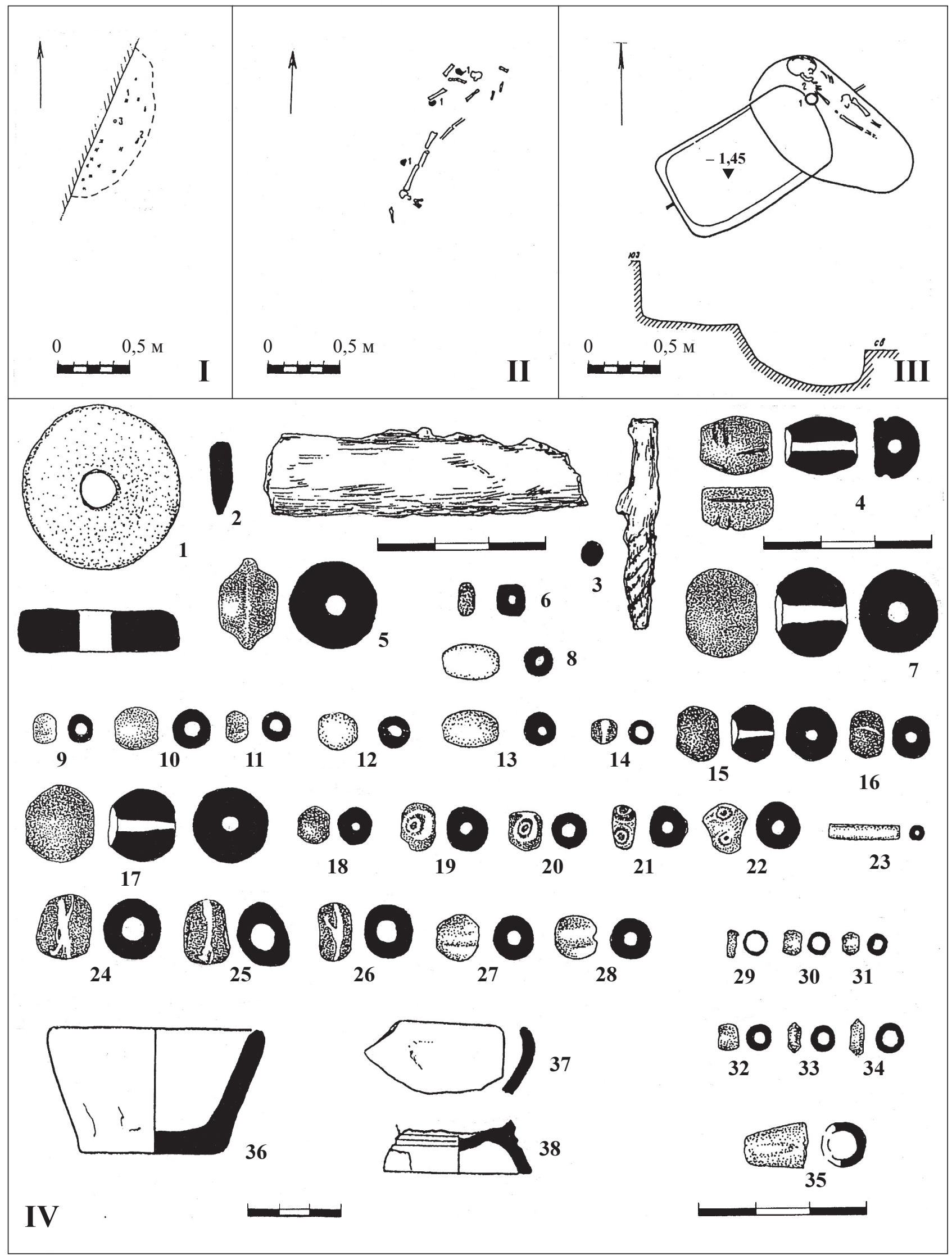

Таблица 20. Могилы 16, 18, 19

I - план могилы 16: 1 - бусы, 2 - нож, 3 - пряслице; II - план могилы 18: 1 - керамика; III - план могилы 19: 1 - миска; 2 - бусы; IV - инвентарь: 1-23, 37 - могила 16; 24-35, 36, 38 - могила 19; 1, 36-38 - керамика; 2, 3 - железо; 4-22, 24-35- стекло; 23 - фаянс; IV, 36-38 - рисунки Э.А. Сымоновича 


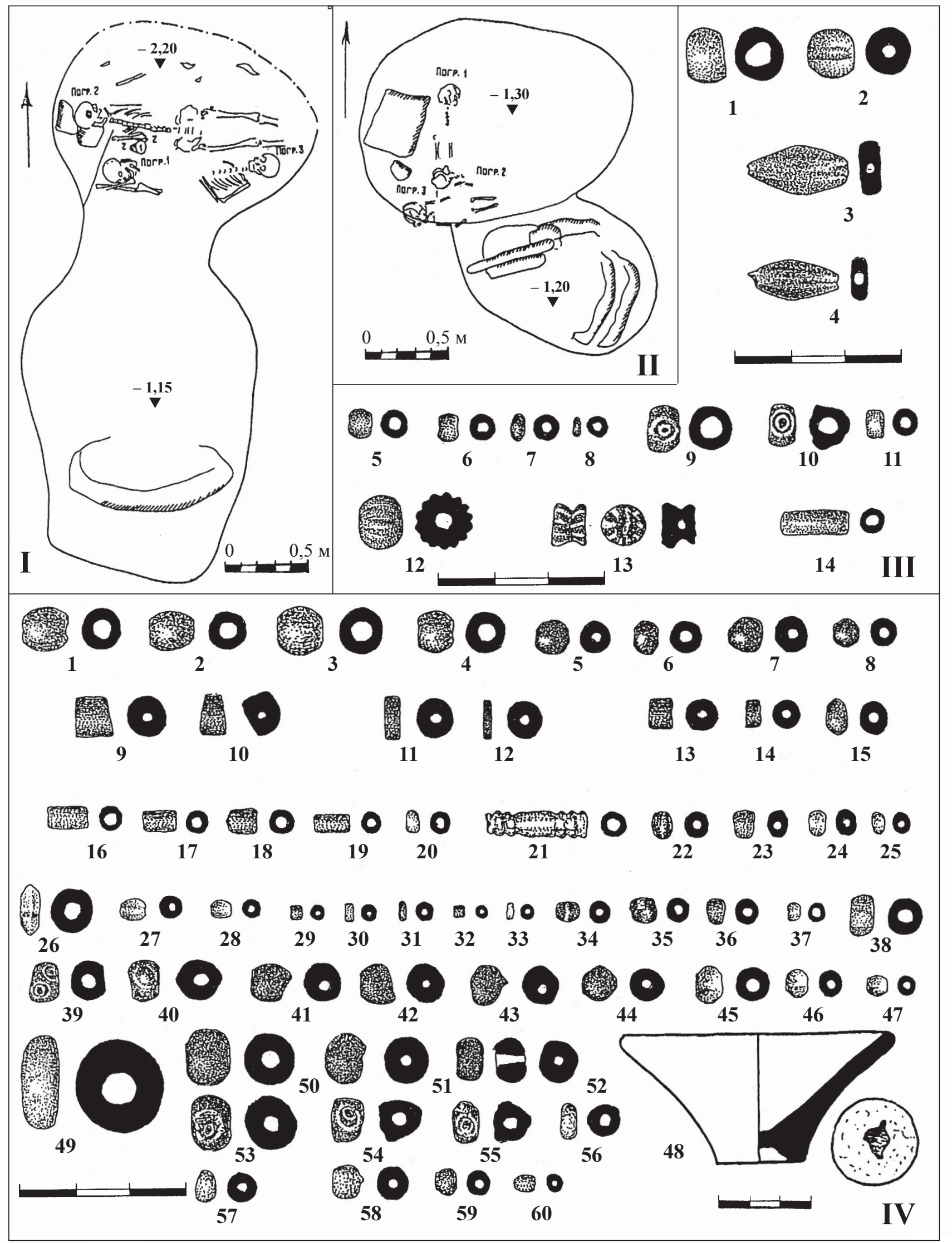

Таблица 21. Могилы 20 и 21

I - план могилы 20: 1 - миска, 2 - бусы; II - план могилы 21: 1 - бусы; III - инвентарь могилы 21: 5-10, 13, 14 - стекло; 11-12 - фаянс; IV - инвентарь могилы 20: 1-25 - погребение 1; $26-48$ погребение 2; 49-60 - погребение 3; 1-8, 16-28, 34-47, 50-60 - стекло; 9-15- гагат; 29-33 - фаянс; 48 - керамика; 49 - янтарь; IV, 48 - рисунок Э.А. Сымоновича 


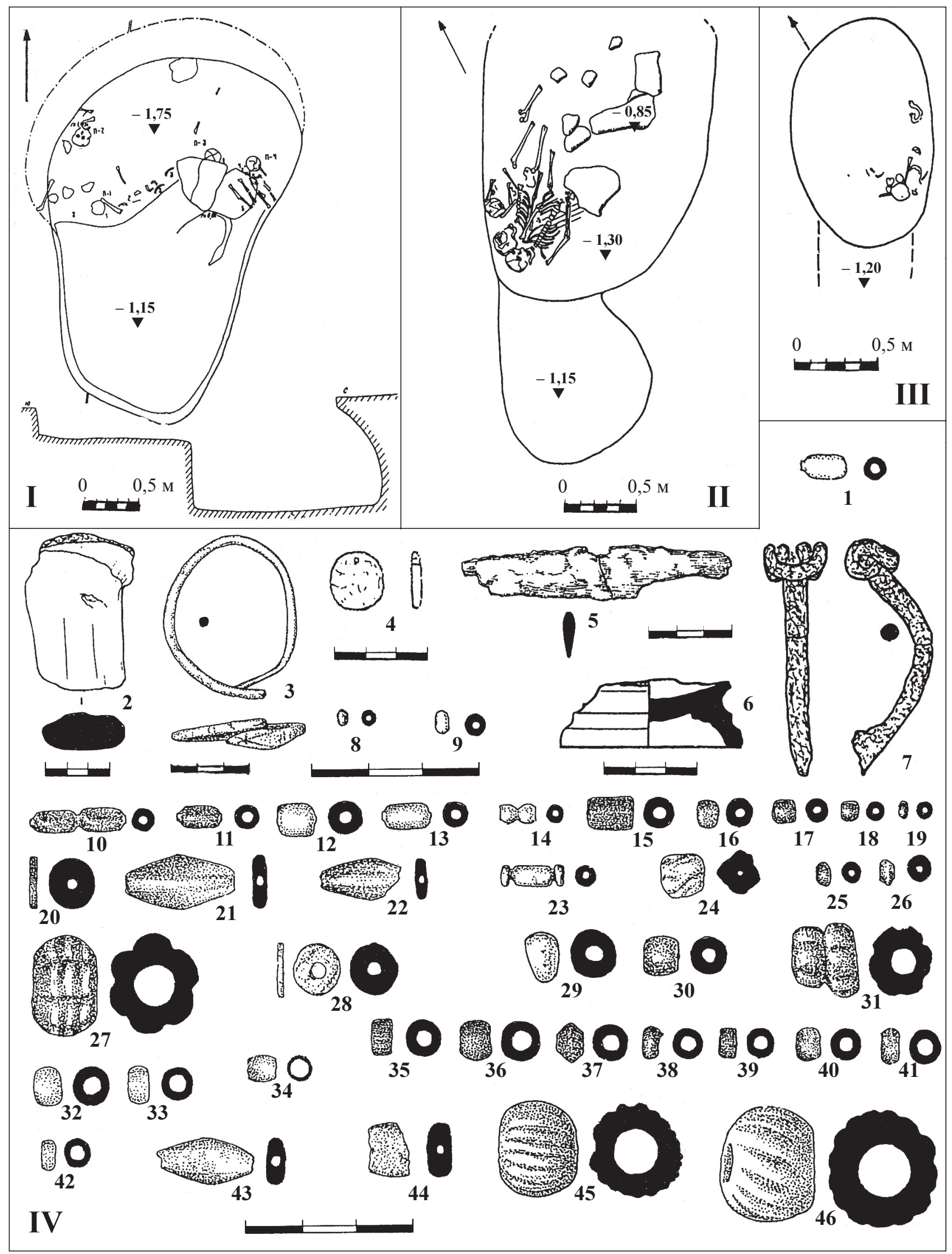

Таблица 22. Могилы $22-24$

I - план и разрез могилы 22: 1 - кости лошади; 2 - кости птицы; 3, 6 - бусы; 4 - подвеска; 5 астрагалы; II - план могилы 23: 1 - сосуд, 2 - фибула, 3 - бусы; штриховкой показана подмазка зеленоватой глиной; III - план могилы 24: 1 - нож; IV - инвентарь: 1, 5 - могила 24; 2-4, 8-31 могила 22; 32-46 - могила 23; 1, 8-23, 25-44 - стекло; 2, 6 - керамика; 3, 4 - бронза; 5,7 железо; 24 - меловая порода; 45, 46 - фаянс; IV, 4, 6, 7 - рисунки Э.А. Сымоновича 


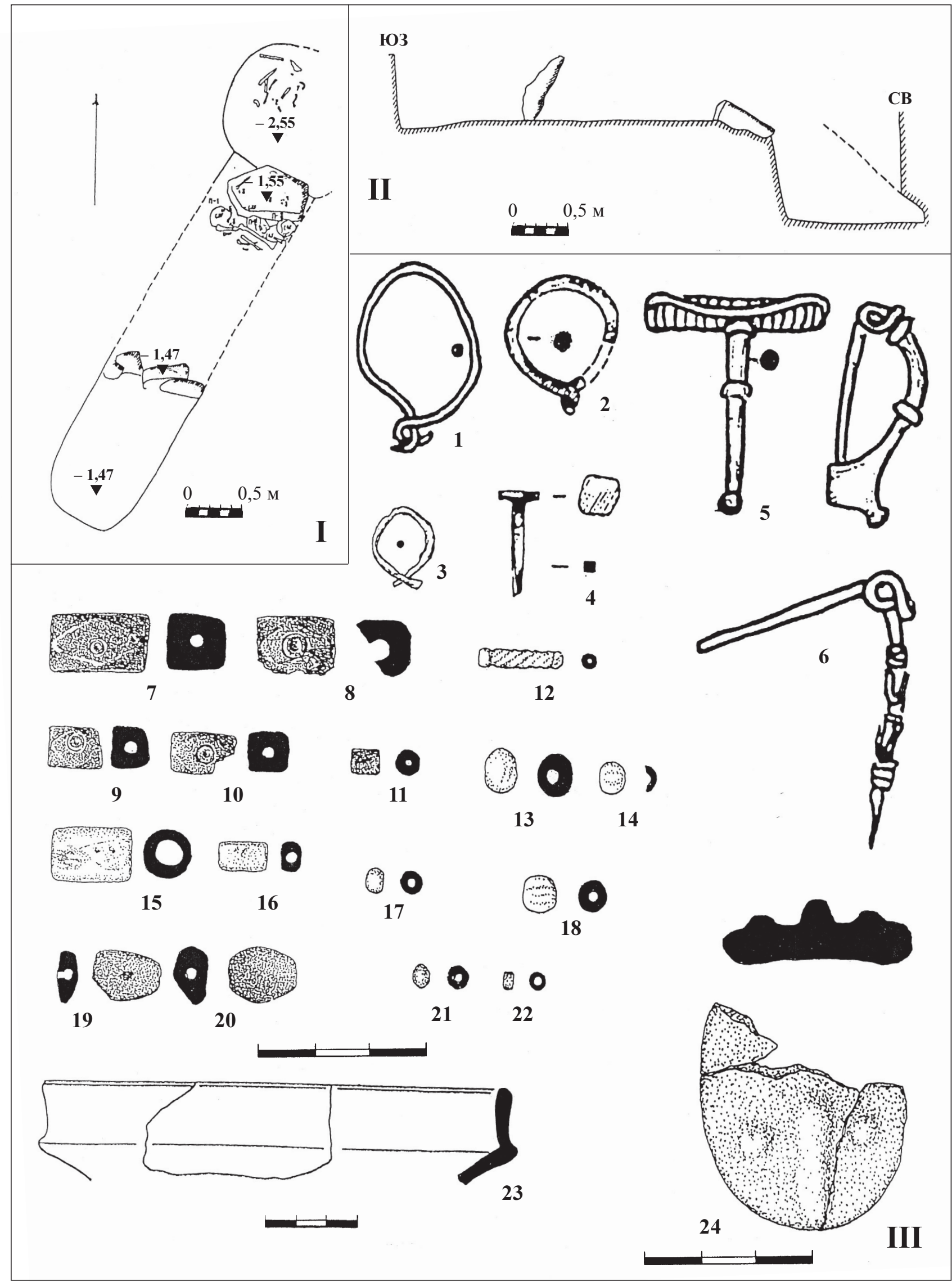

Таблица 23. Могила 25

I - план могилы 25: 1 - гвозди; 2 - бусы; 3, 4 - бронзовые предметы; 5 - фибулы; 6 - личина; II - разрез; III - инвентарь: 1-6 - бронза; 7-11 - гагат; 12-18 - стекло; 19, 20 - янтарь; 21, 22 фаянс; 1, 2, 4-6, 23 - рисунки Э.А. Сымоновича 


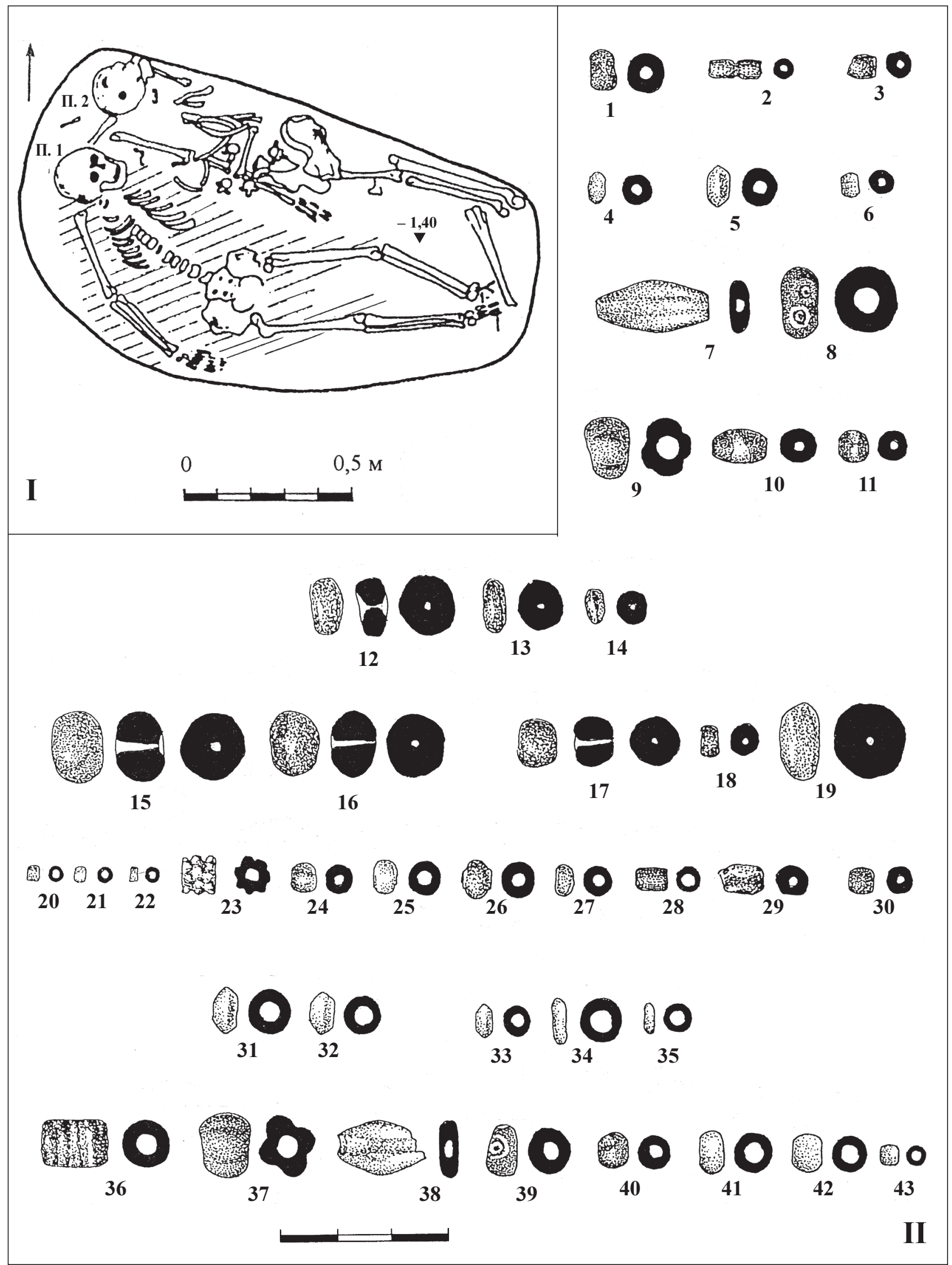

Таблица 24. Могила 26

I - план: 1 - бусы с ног; 2 - бусы с шеи (погребение 1); 3 - бусы с шеи (погребение 2); II инвентарь: 1-30 - погребение 1; 31-43 - погребение 2; 1-8, 10, 11, 23-36, 38-43 - стекло; 9, 20 22, 37 - фаянс; 12-19 - сердолик; штриховкой показана подмазка зеленоватой глиной 


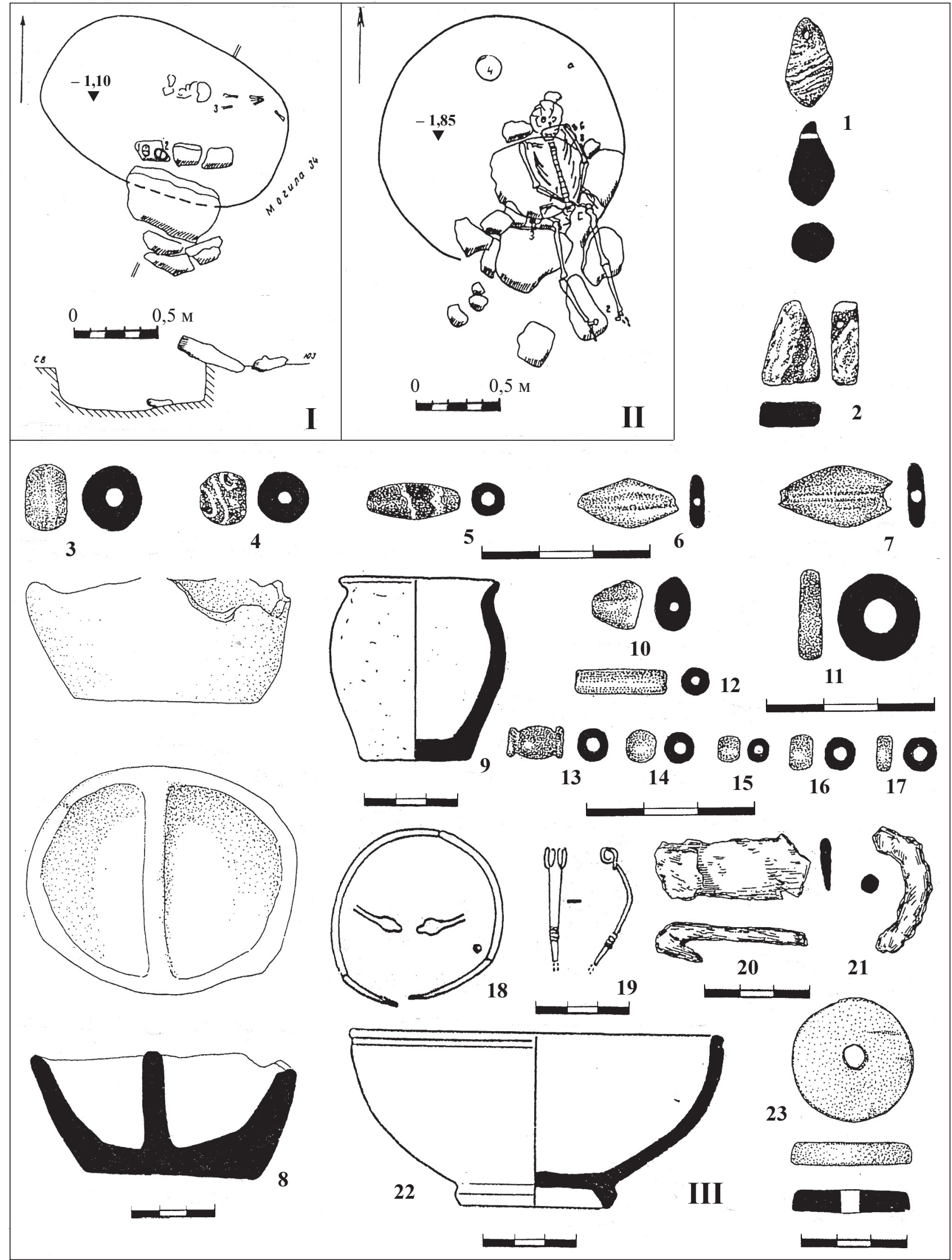

Таблица 25. Могилы 27 и 28

I - план и разрез могилы 27: 1, 2 - сосуды; 3 - бусы; II - план могилы 28: 1 - браслет; 2 - бусы с ног; 3 - зеркало; 4 - миска; III - инвентарь: 1-9 - могила 27; 10-23 - могила 28; 1-7, 12, 13-17 - стекло; 8, 9, 22, 23 - керамика; 18, 19 - бронза; 20, 21 - железо; 9, 18, 19, 22 - рисунки Э.А. Сымоновича 


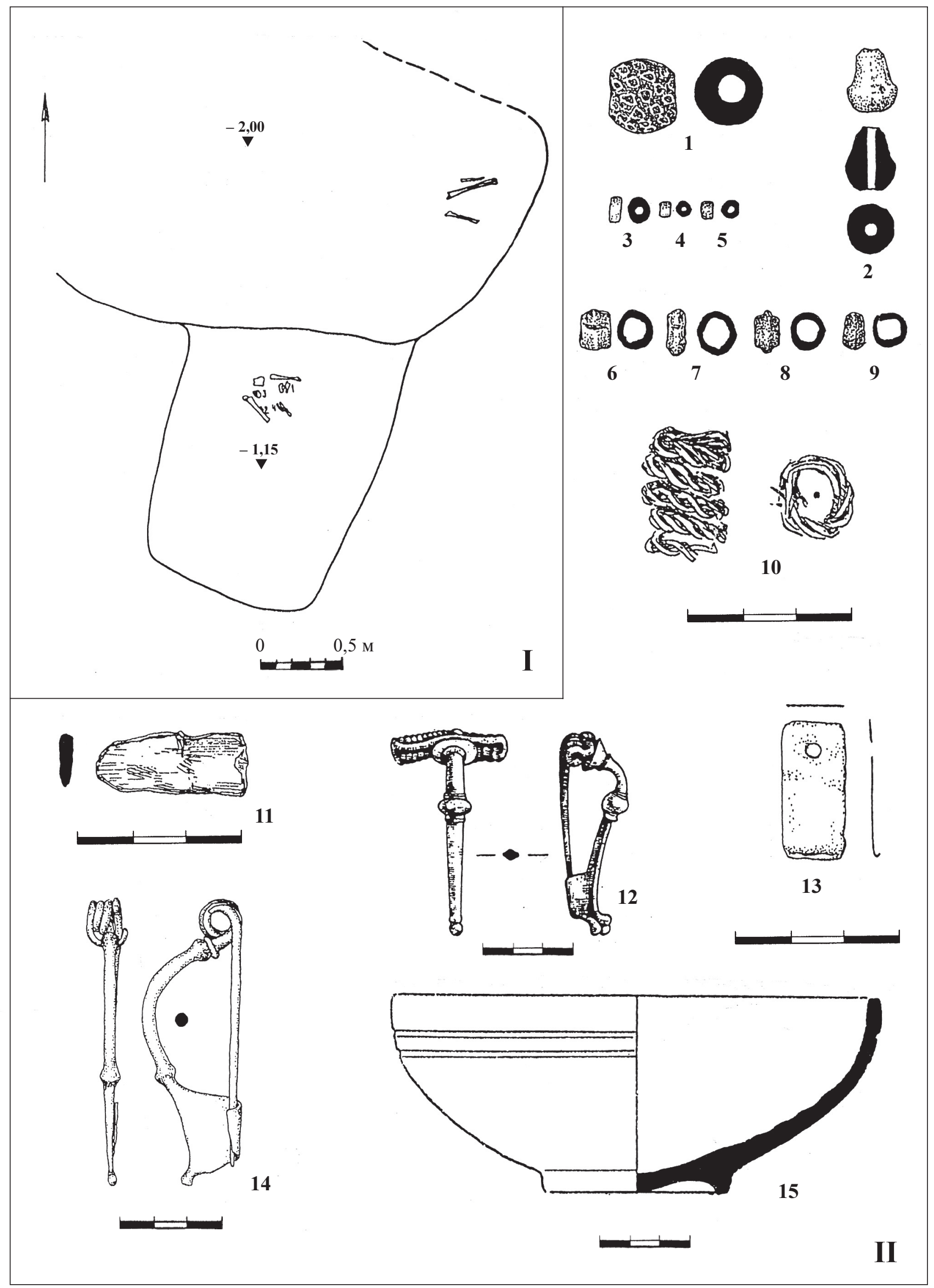

Таблица 26. Могила 29

I - план: 1 - фибула; 2 - проволочный цилиндр; 3 - керамика; 4 - бусы; 1, 2, 6-9 - стекло; 3-5 фаянс; 10, 12-14 - бронза; 11 - железо; 15 - керамика; 12, 15 - рисунки Э.А. Сымоновича 


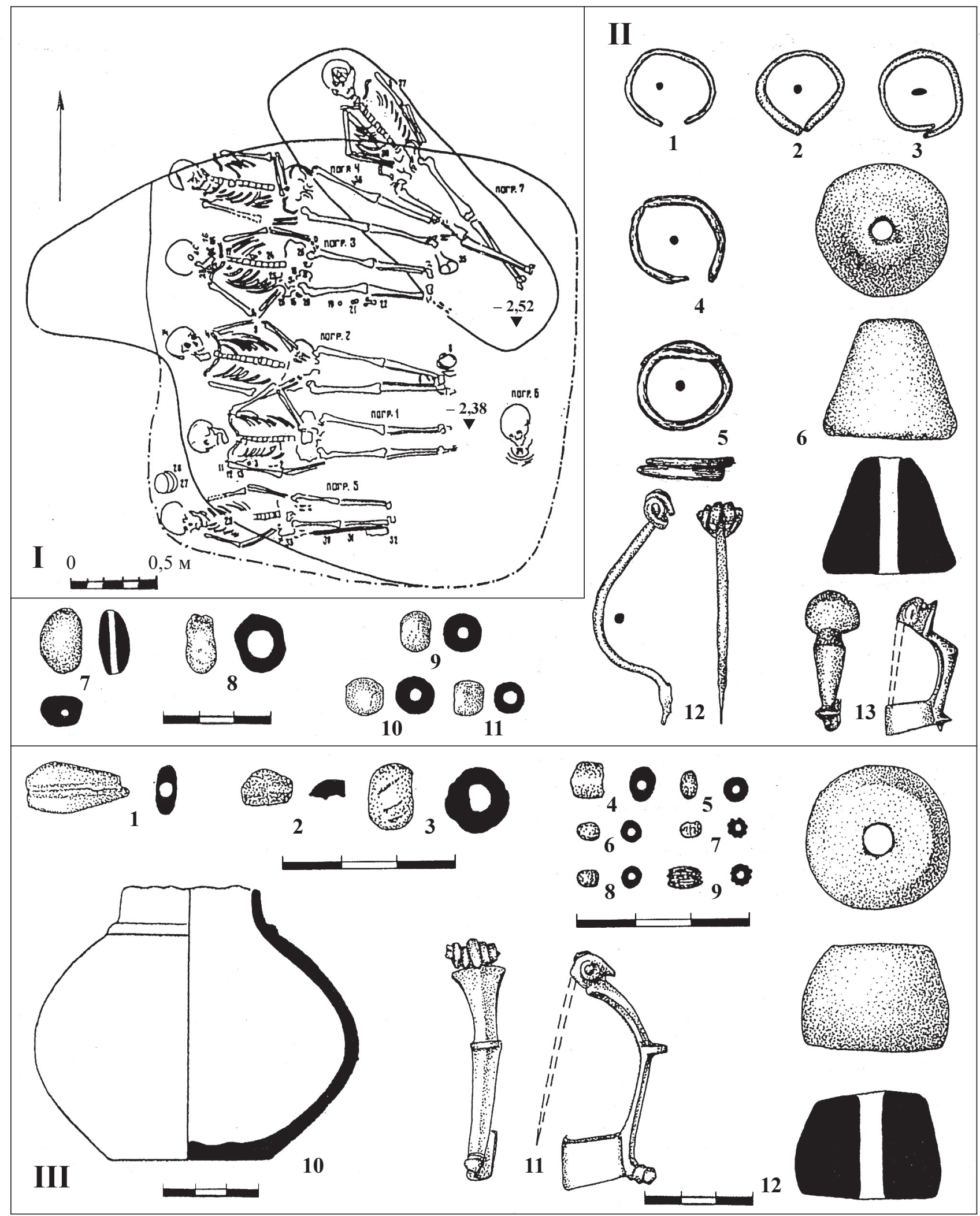

Таблица 27. Могила 30, погребения 1 и 2

I - план: 1 - фибула и две бусины; 2 - пронизка; 3 - колечко; 4 - бусы; 5 - фибула; 6 - пряслице; 7 - обломок железного предмета; 8 - сосуд; 9 - фибула; 10 - бусы с шеи; 11 - фибула; 12 бусина; 13, 14 - кольца; 15 - браслет; 16 - эмалевая фибула; 17 - фибула, 18 - перстень; 19 игла; 20 - фибула; 21 - халцедоновые бусы; 22 - кольца (2 шт.); 23 - бусы с шеи; 24 - янтарная подвеска; 25 - фибула; 26- бусы; 27, 28 - сосуды; 29 - бусы с груди; 30 - меч; 31 - кинжал; 32 - антропоморфный сосуд; 33 - навершие рукояти меча; 34 - гривна; 35 - кость животного; 36 - нож; 37 - фибула; 38 - бусы; II - инвентарь погребения 1: 1-5, 12, 13 - бронза; 6 - глина; 7 - янтарь; 8 - мел; 9-11 - стекло; III - инвентарь погребения 2: 1, 2, 4-9 - стекло; 3 - фаянс; 10, 12 - глина; 11 - бронза; III, 10 - рисунки Э.А. Сымоновича 


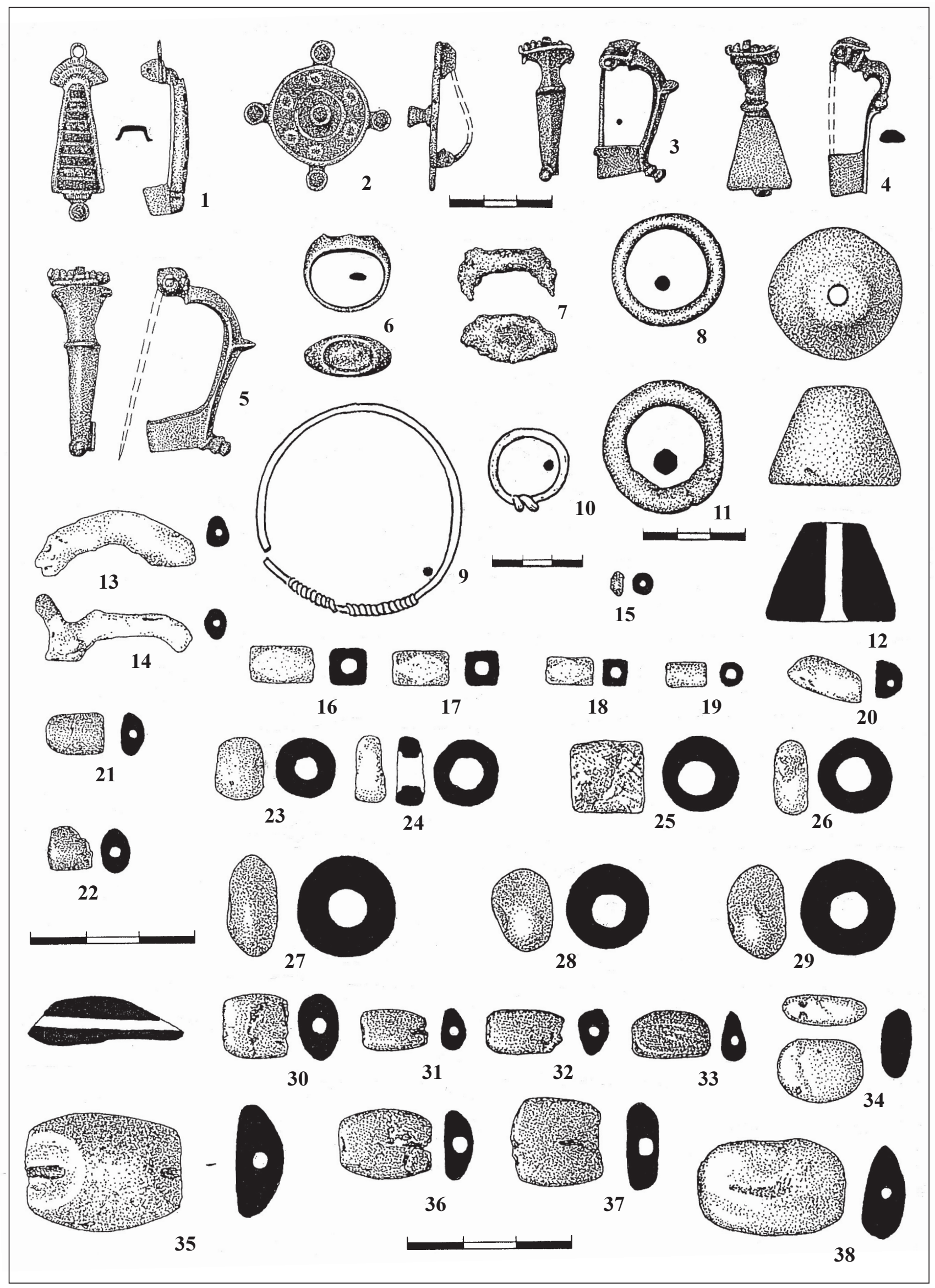

Таблица 28. Могила 30, погребение 3. Инвентарь:

1-11 - бронза; 12 - глина; 13, 14 - кораллы; 15-20 - стекло; 21, 22, 30-38 - янтарь; 23-26 меловая порода; 27-29 - халцедон; 9, 10 - рисунки Э.А. Сымоновича 

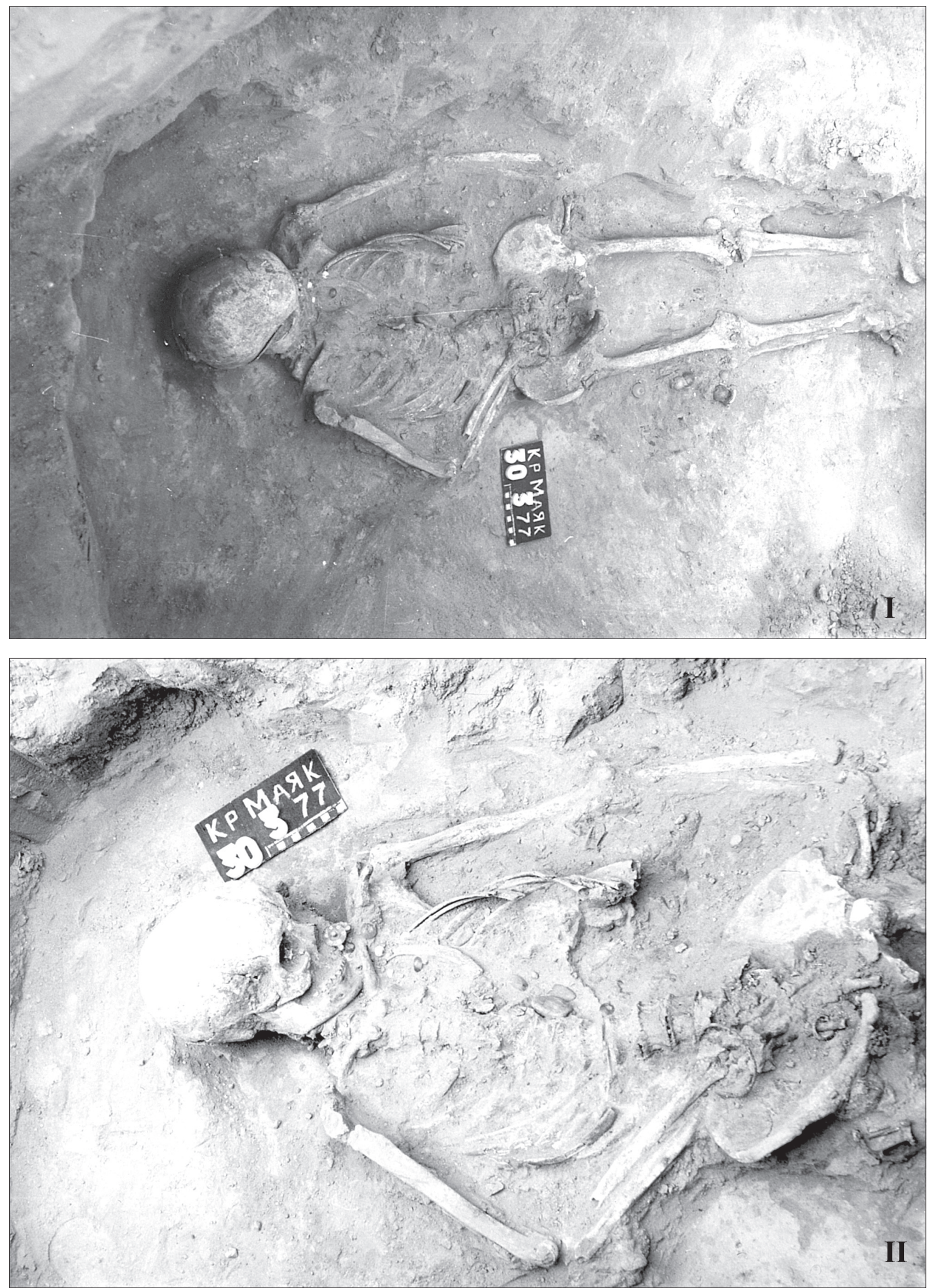

Таблица 29. Могила 30, погребение 3

I - общий вид погребения; II - верхняя часть скелета (с левой стороны от нижней челюсти хорошо видна бронзовая фибула - брошь с эмалями) 


\section{$0030000000=$
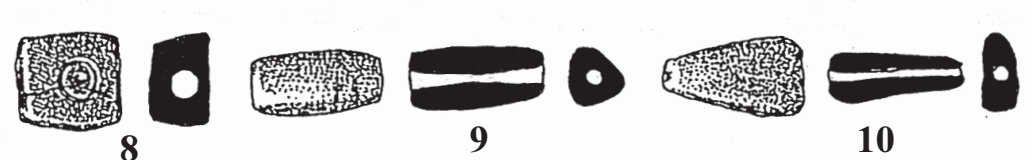 \\ 10

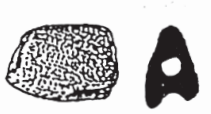 \\ 11

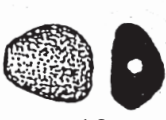 \\ 12

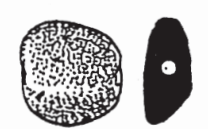 \\ 13

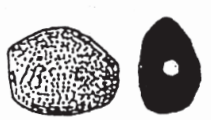 \\ 14}

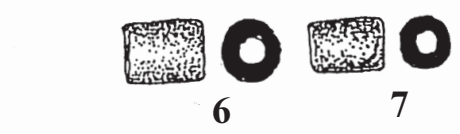

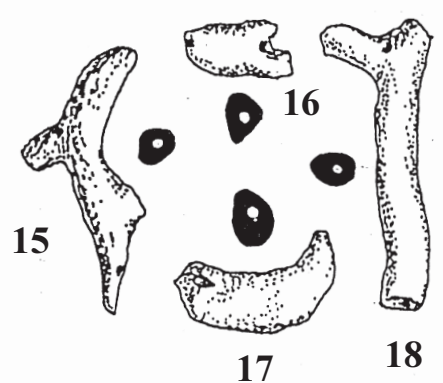

17

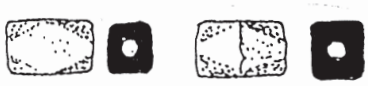

19 20

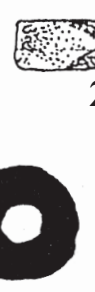

27

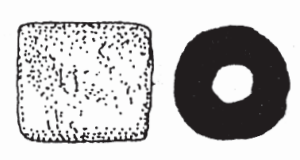

21

0

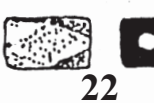

23
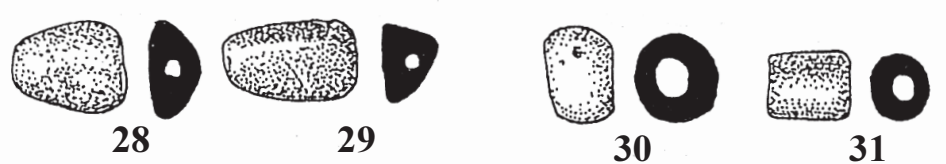

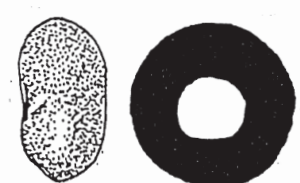

32

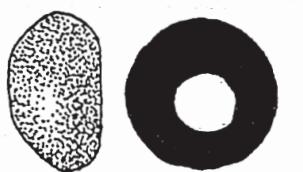

33

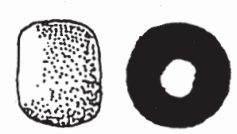

34

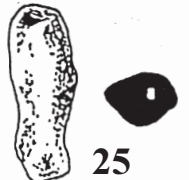

24

25

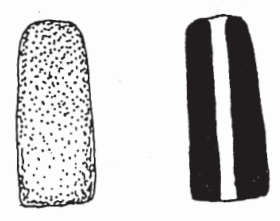

37
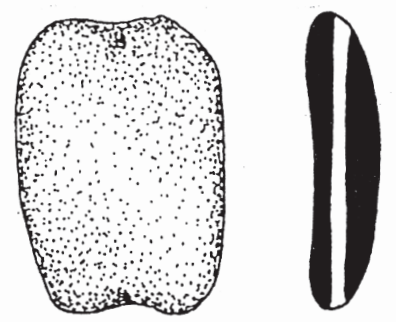

41
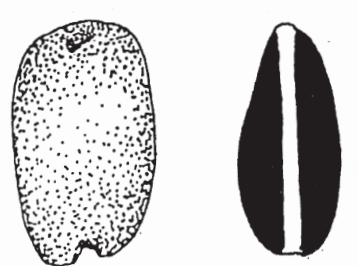

00000 39
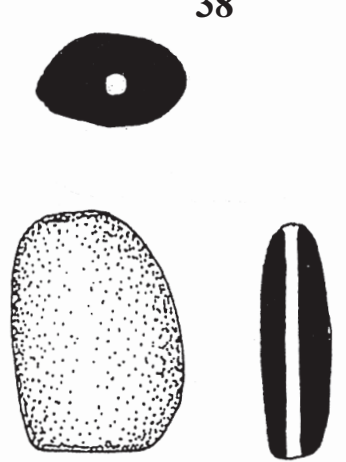

42
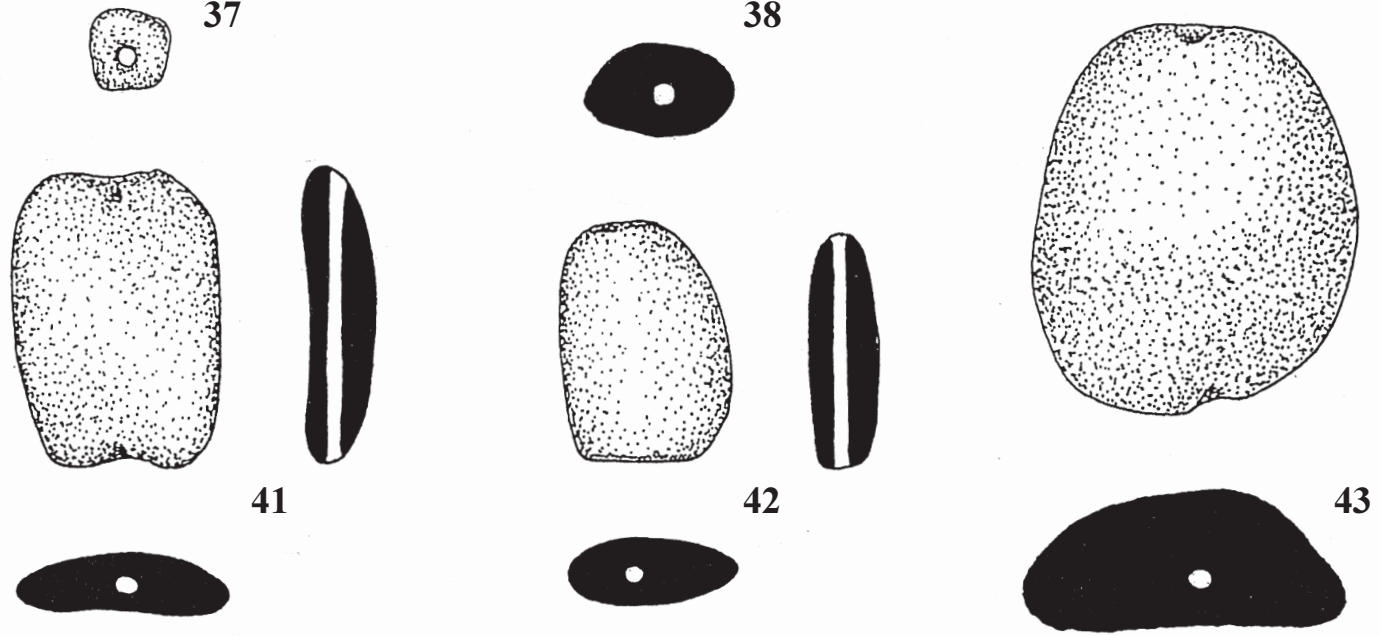

36

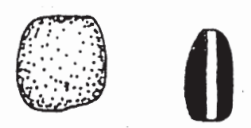

- 40

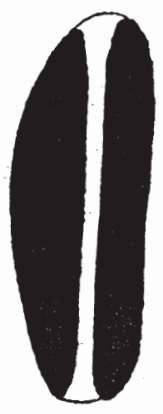

43

35

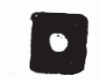

Таблица 30. Могила 30, погребение 3. Бусы

1-7, 19-24, 31, 36, 39 - стекло; 8 - гагат; 9-14, 28, 29, 37, 38, 40-43 - янтарь; 15-18 - кораллы; 25 - бронза; 26, 27, 30, 34, 35 - меловая порода; 32, 33 - халцедон 


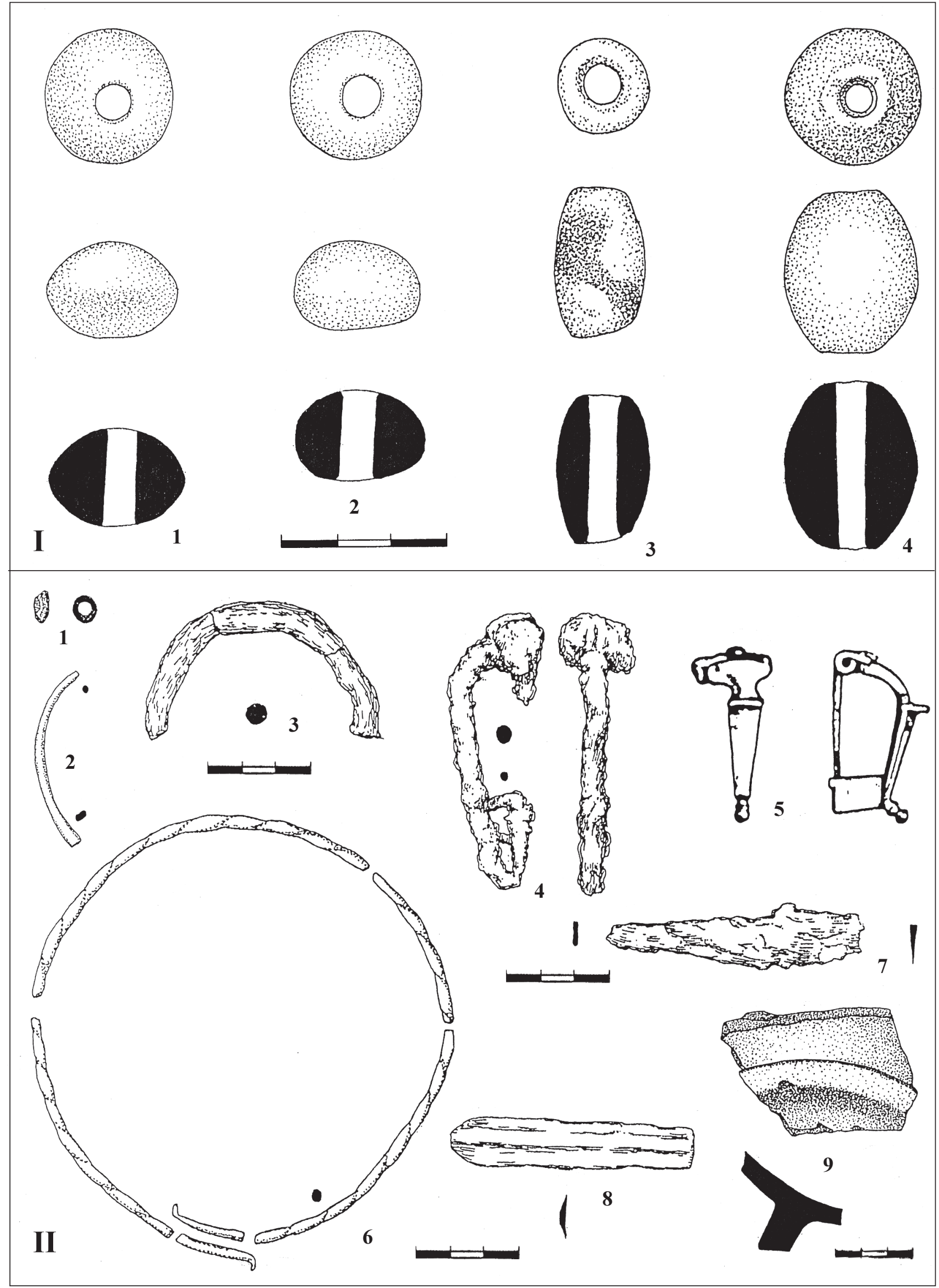

Таблица 31. Могила 30. Инвентарь погребений 3, 4, 6, 7 и заполнения могилы

I - халцедоновые бусы из погребения 3; II - инвентарь погребений 3, 4, 6, 7 и заполнения: 1 , 4 - погребение 7; 2, 7, 9 - погребение 4; 3,6 - погребение 6; 5, 8 - заполнение; 1 - стекло; 2, 5, 6 - бронза; 3, 4, 7 - железо; 8 - кремень; 9 - керамика; II, 2, 5 - рисунки Э.А. Сымоновича 


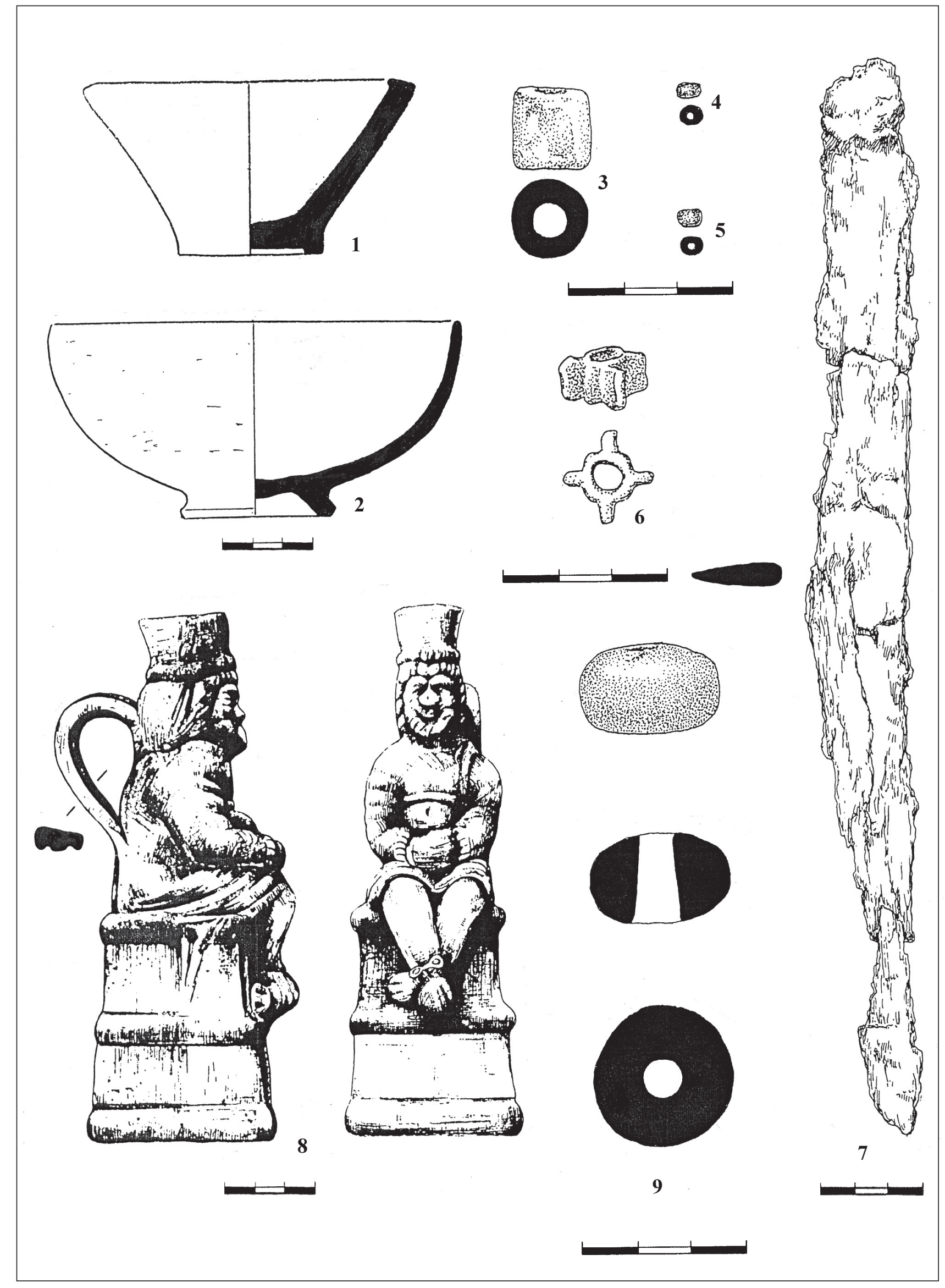

Таблица 32. Могила 30. Инвентарь погребения 5

1, 2 - керамика; 3 - меловая порода; 4, 5 - стекло; 6 - бронза; 7 - железо; 8 - терракота; 9 халцедон; 1, 2, 8 - рисунки Э.А. Сымоновича 


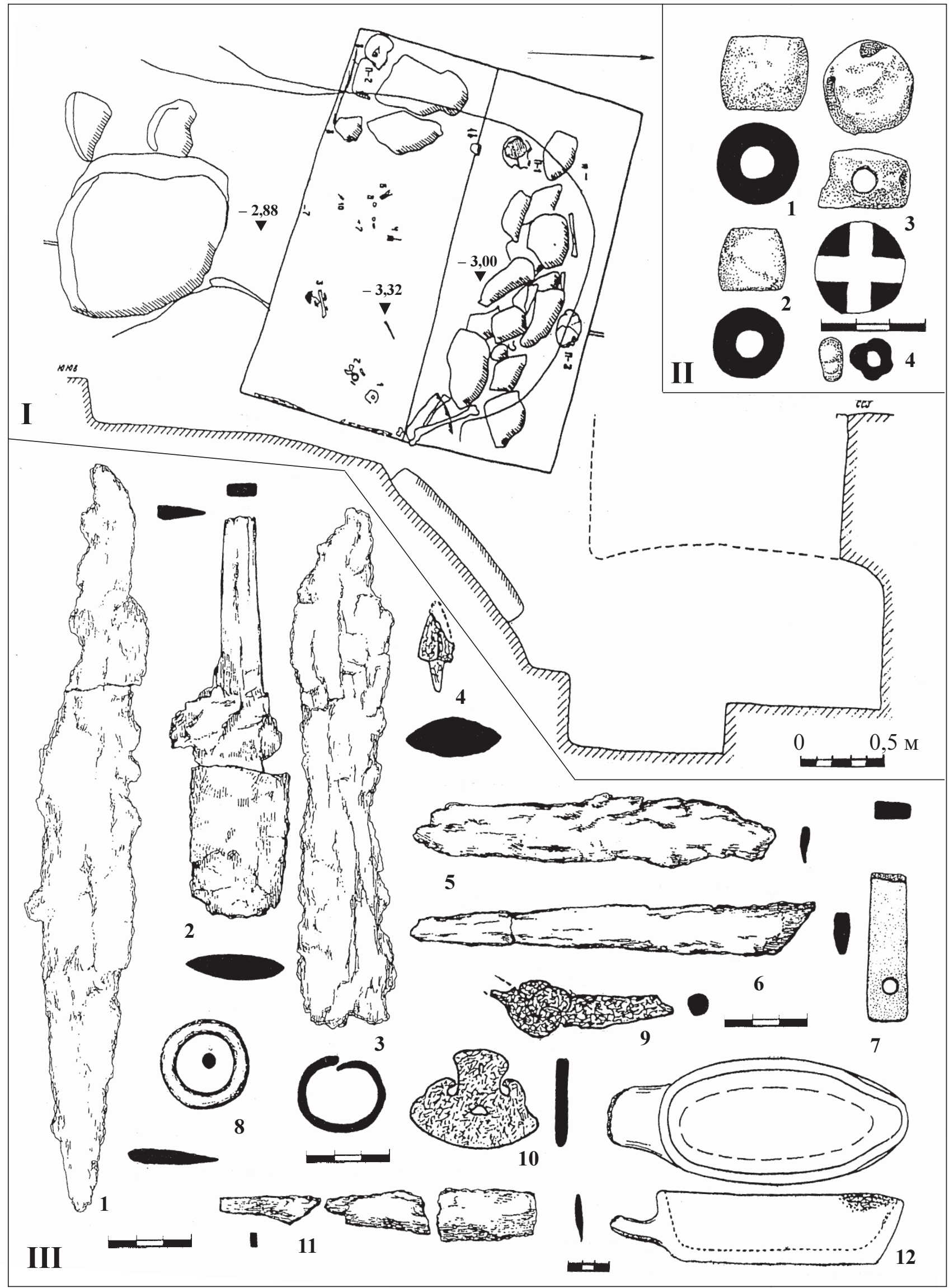

Таблица 33. Могила 31

I - план и разрез: 1 - кусок черепа с отверстием, 2 - бронзовое кольцо и обломки железа, 3 обломки железных предметов, 4 - рукоять меча, 5 - меловые бусы и пронизка, 6 - обломок лезвия меча, 7 - чешуйки золота, 8 - наконечник копья, 9 - череп человека, 10 - наконечник стрелы; II - бусы: 1-3 - меловая порода; 4 - стекло; III - инвентарь: 1-6, 9-11 - железо; 7 камень; 8 - бронза; 12 - глина 


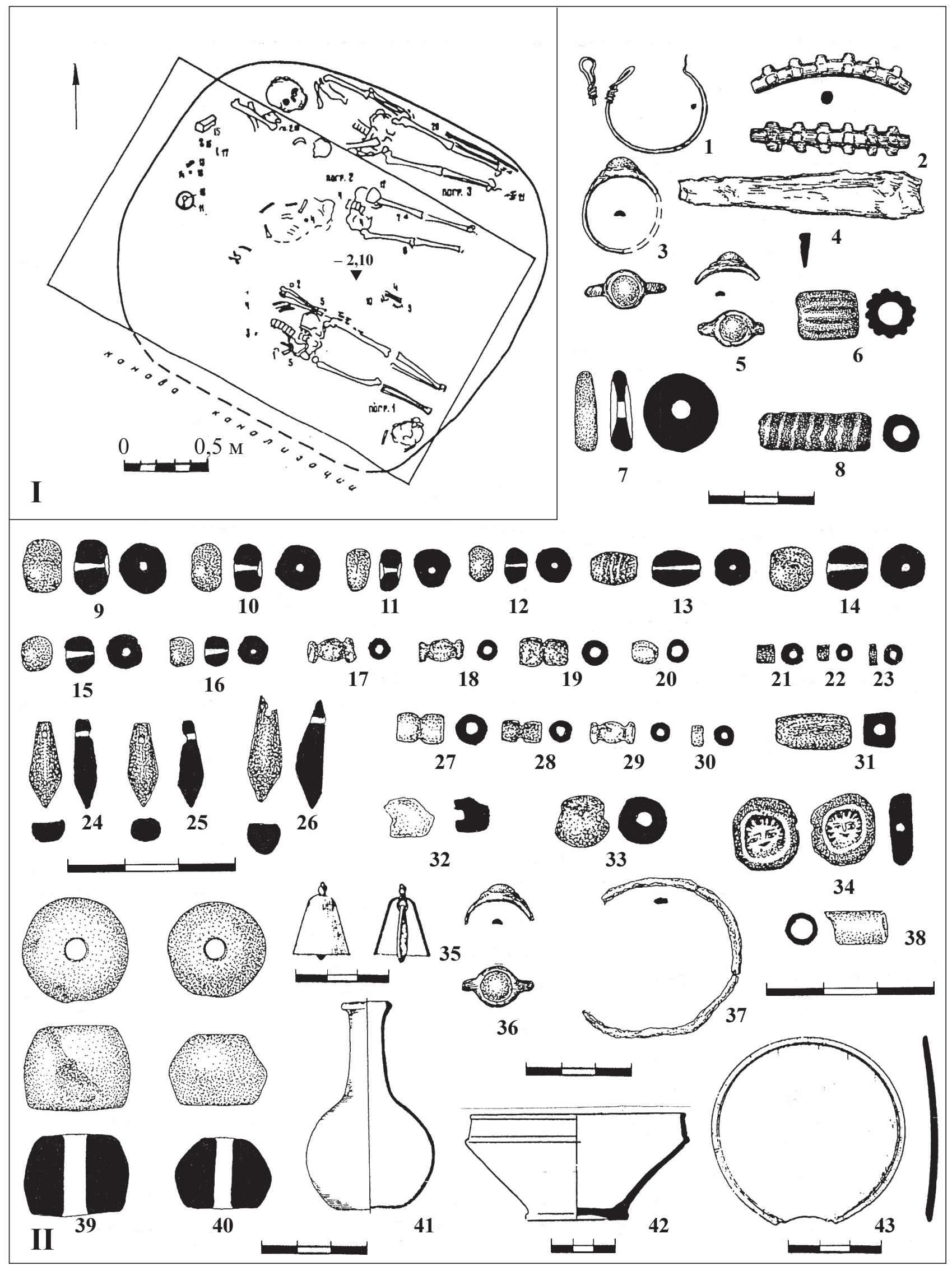

Таблица 34. Могила 32

I - план: 1 - серьга; 2 - часть кольца; 3 - бронзовый предмет; 4, 6 - бусы; 5 - обломки железных предметов; 7 - колокольчик; 8 - браслет; 9 - кольцо с выступами; 10 - перстни (3 штуки); 11 миска; 12 - флакон; 13 - дерево от шкатулки; 14 - румяна и охра; 15 - герма; 16 - пряслица (2 шт.); 17 - железный предмет; 18 - смола; 19 - перстни (2 шт.); 20 - меч; 21 - наконечники стрел; II - инвентарь: 1-25 - погребение 1; 26-43 - погребение 2; 1-3, 5, 35-38, 43 - бронза; 4 железо; 39, 40, 42 - глина; 6-8, 17-20, 27-34 - стекло; II, 35, 42, 43 - рисунки Э.А. Сымоновича 


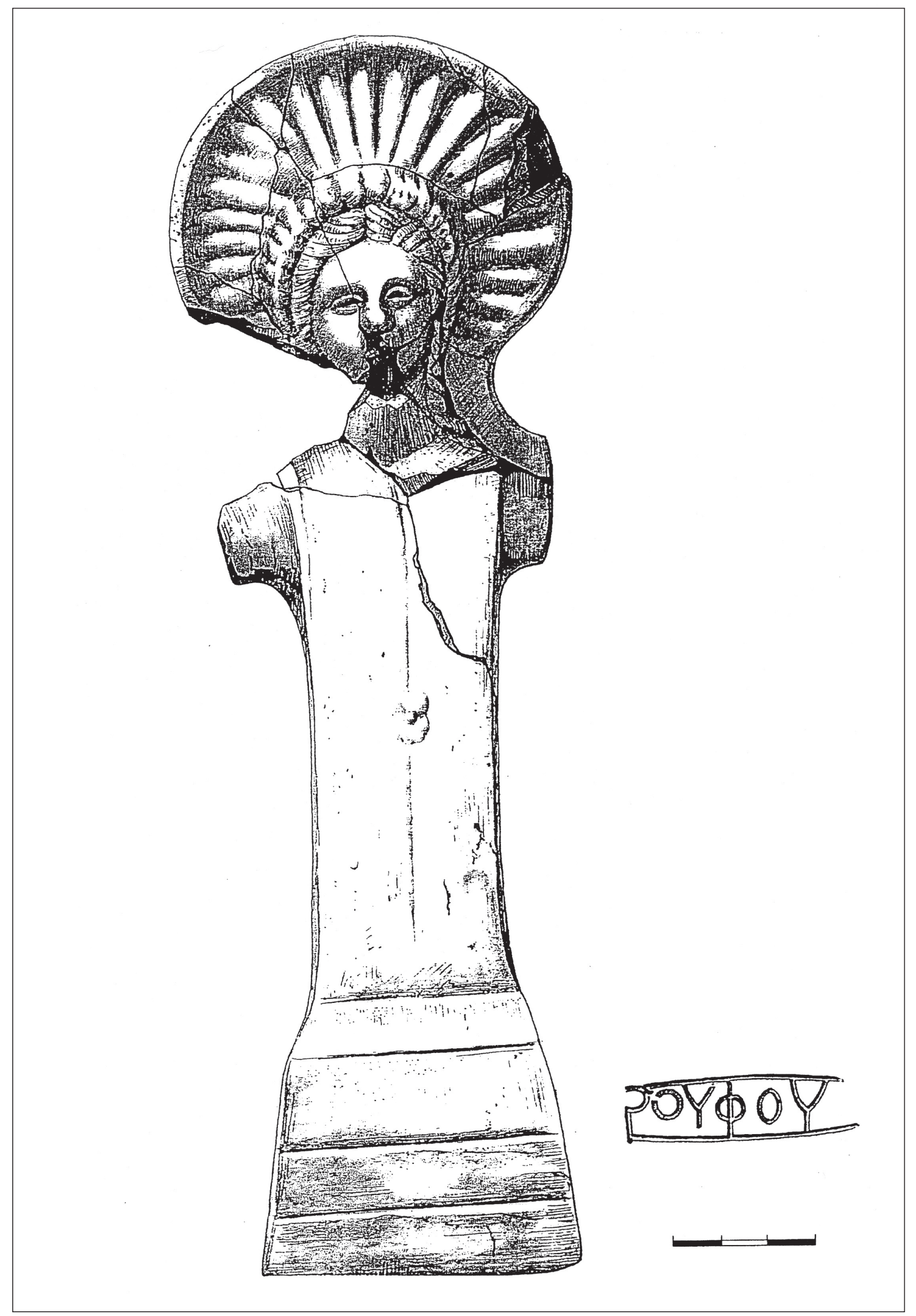

Таблица 35. Герма из могилы 32 


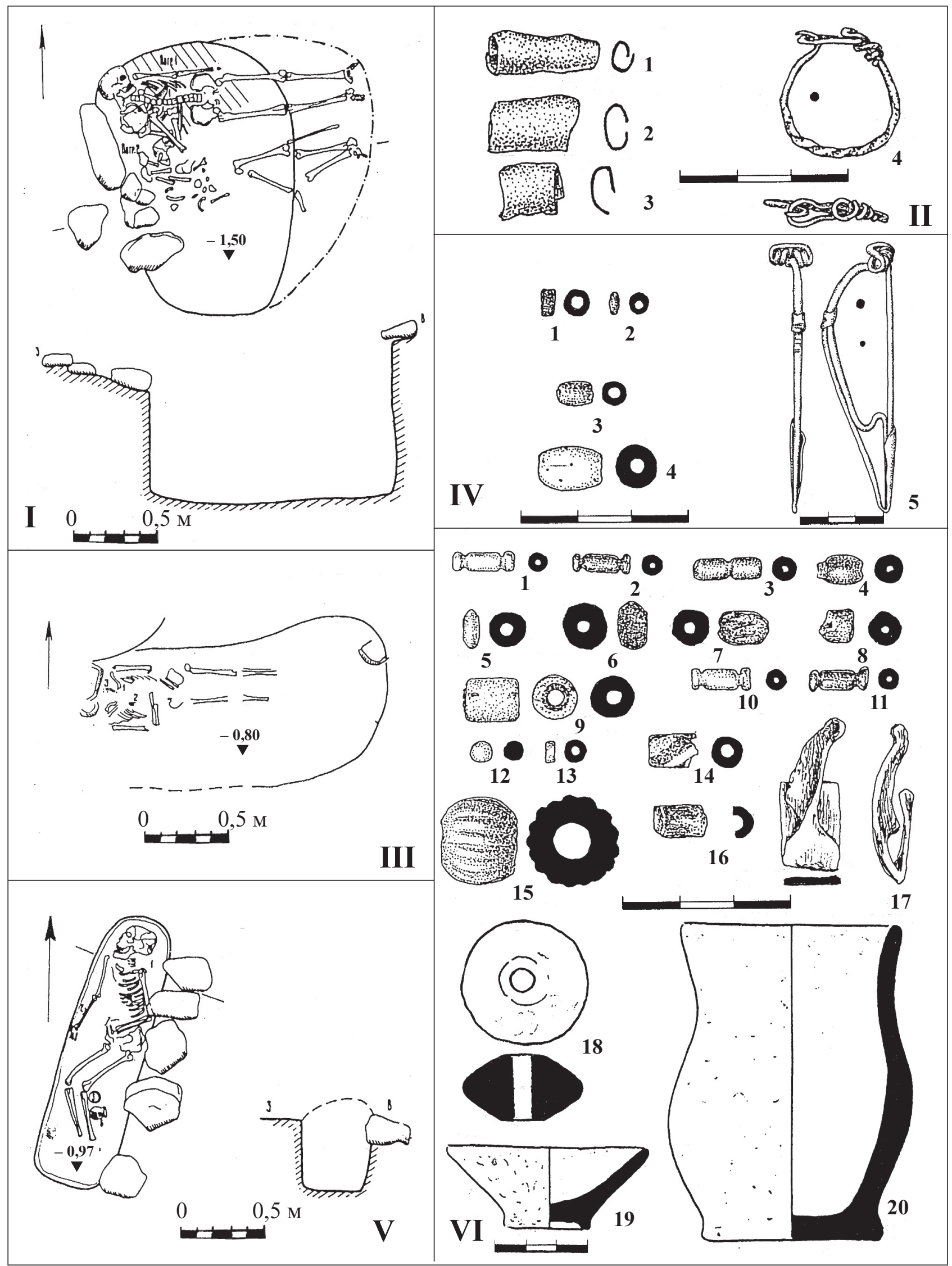

Таблица 36. Могилы 33, 34 и 36

I - план и разрез могилы 33: 1 - обломки амфор, 2 - обломки бронзовых предметов; штриховкой показана подмазка зеленоватой глиной; II - инвентарь могилы 33: 1-4 - бронза; III - план могилы 34: 1- фибула; 2 - железный предмет; 3 - бусы; IV - инвентарь могилы 34: 1-4 - стекло; 5 - бронза; V - план и разрез могилы 36: 1-3 - бусы и пронизи; 5-6 - сосуды; VI - инвентарь могилы 36: 1-14, 16 - стекло; 15 - фаянс; 17 - бронза; 18-20 - глина; VI, 18-20 - рисунки Э.А. Сымоновича 


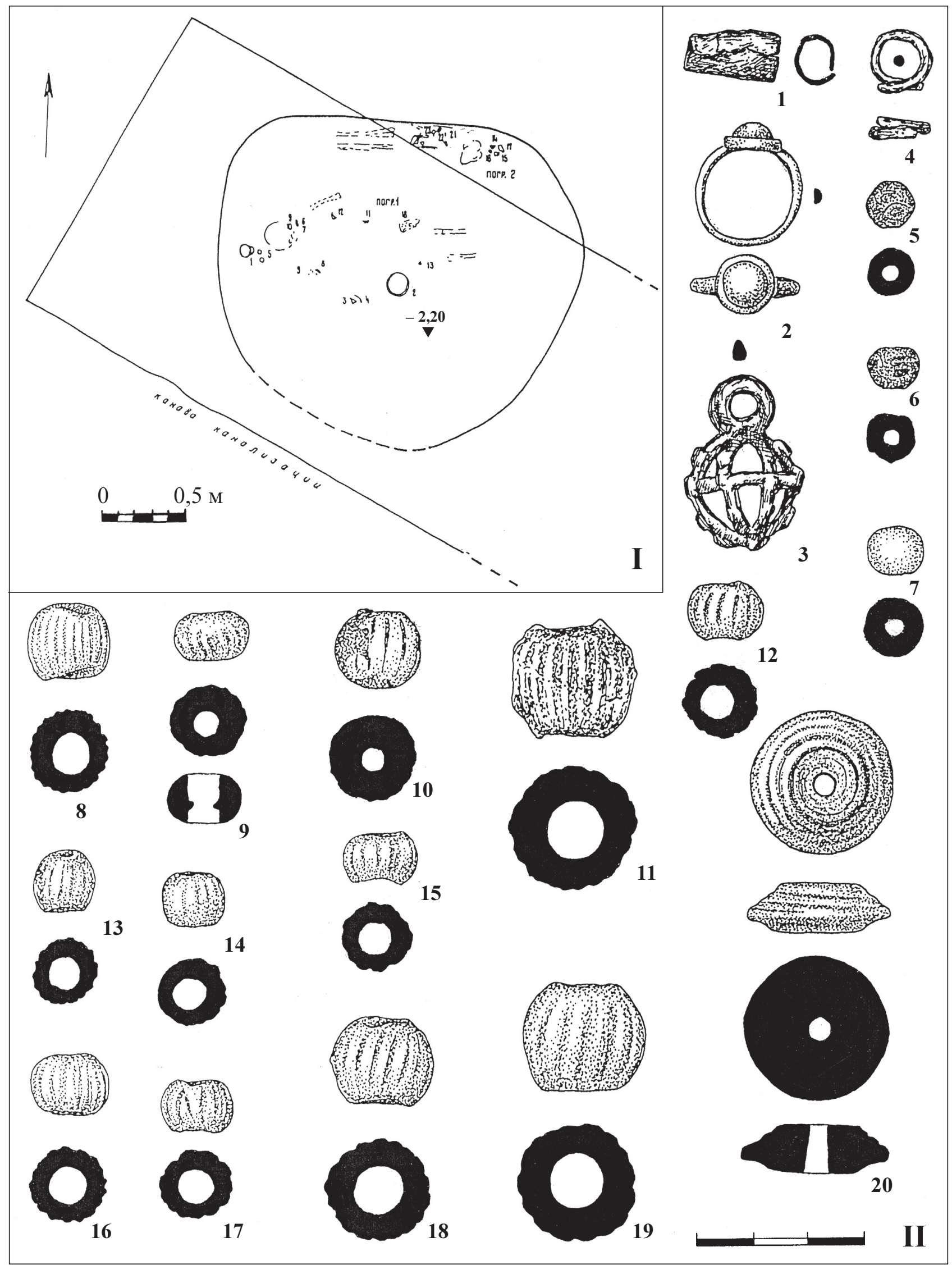

Таблица 37. Могила 35

I - план: 1-2 - сосуды; 3 - колокольчик; 4, 22, 23 - браслеты; 5, 14, 15 - глиняные пряслица; 6 , 19 - рамчатые фибулы; 7 - бронзовый предмет; 8 - лучковая фибула; 9 - бусы; 10 - наконечник пояса; 11, 12 - фибулы (сильно профилированные); 13 - железный предмет; 16 - свинцовое пряслице; 17 - точильный брусок; 18 - отстатки шкатулки с украшениями; 20 - сердоликовые бусы; 21 - фибула с гребнем на спинке; II - предметы из шкатулки: 1-3 - бронза; 4-7 - стекло; $8-19$ - фаянс 


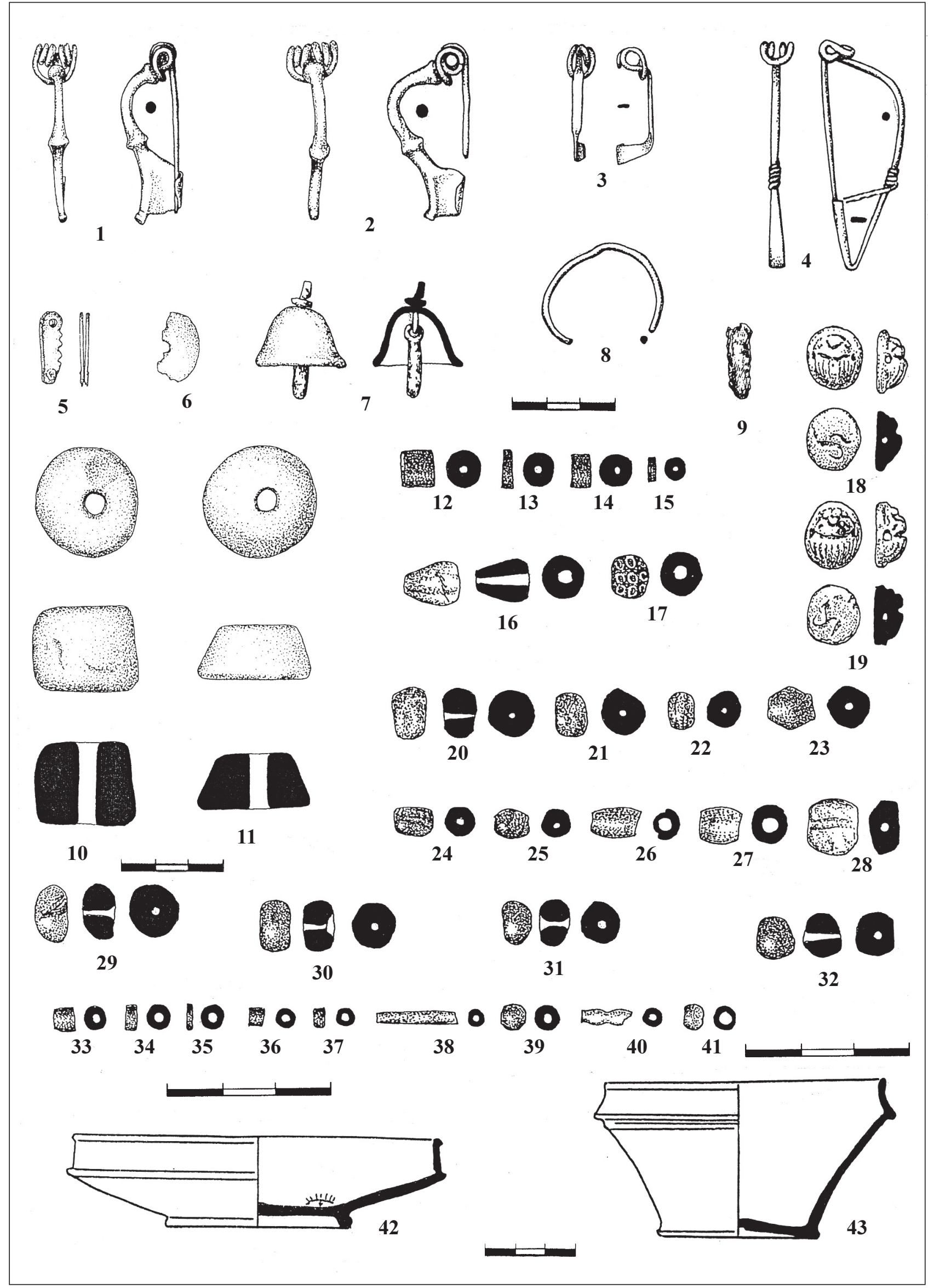

Таблица 38. Могила 35, погребение 1 , инвентарь

1-8 - бронза; 9 - железо; 10, 11, 42, 43 - глина; 12-15, 33-37 - гагат; 16-27, 38-41 - стекло; 29-32 - сердолик 


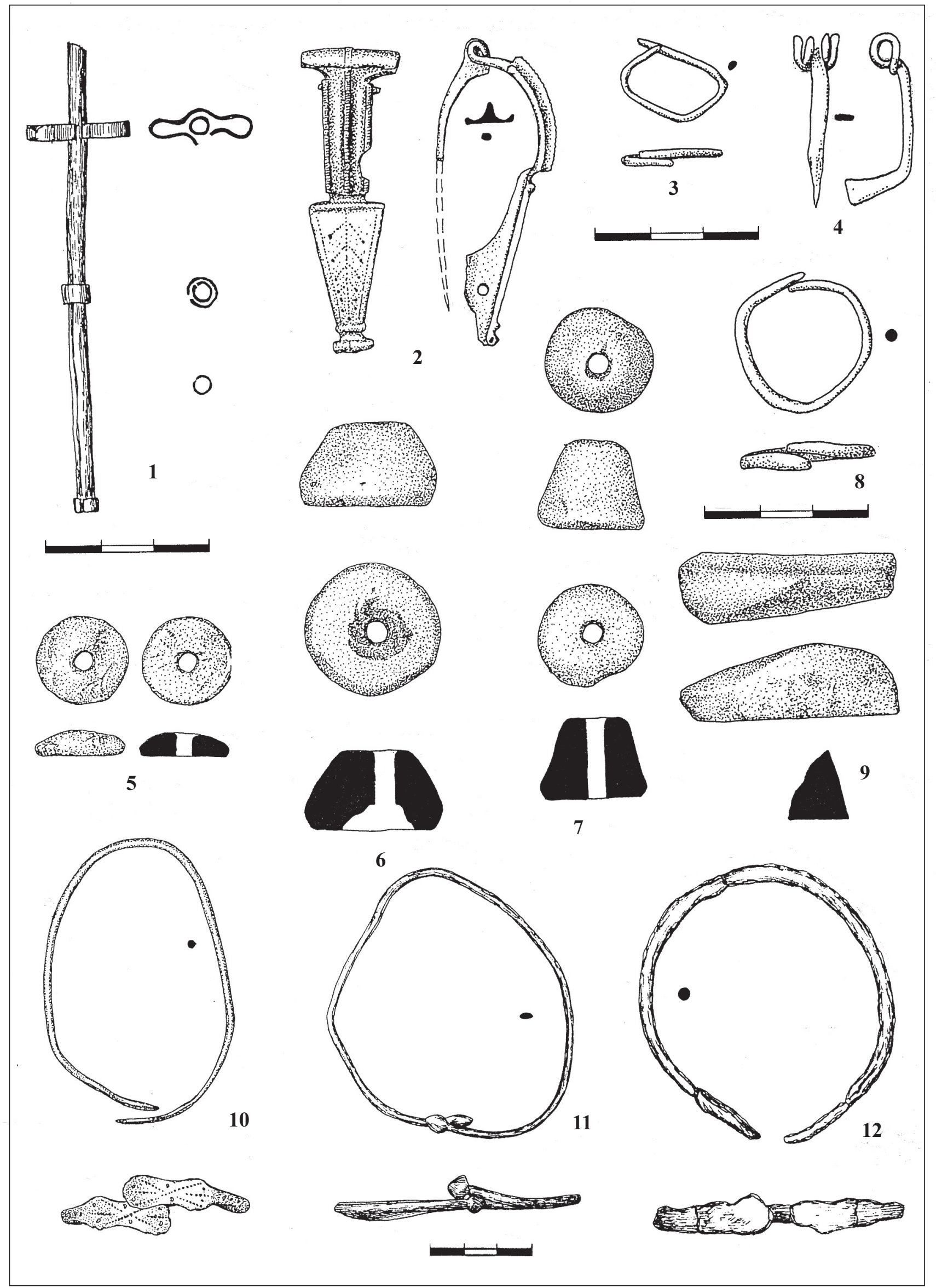

Таблица 39. Могила 35. Инвентарь

1, 2, 4-7, 9-11 - погребение2; 3, 8, 12 - заполнение; 1-4, 8, 10-12 - бронза; 5 - свинец; 6, 7 глина; 9 - камень 


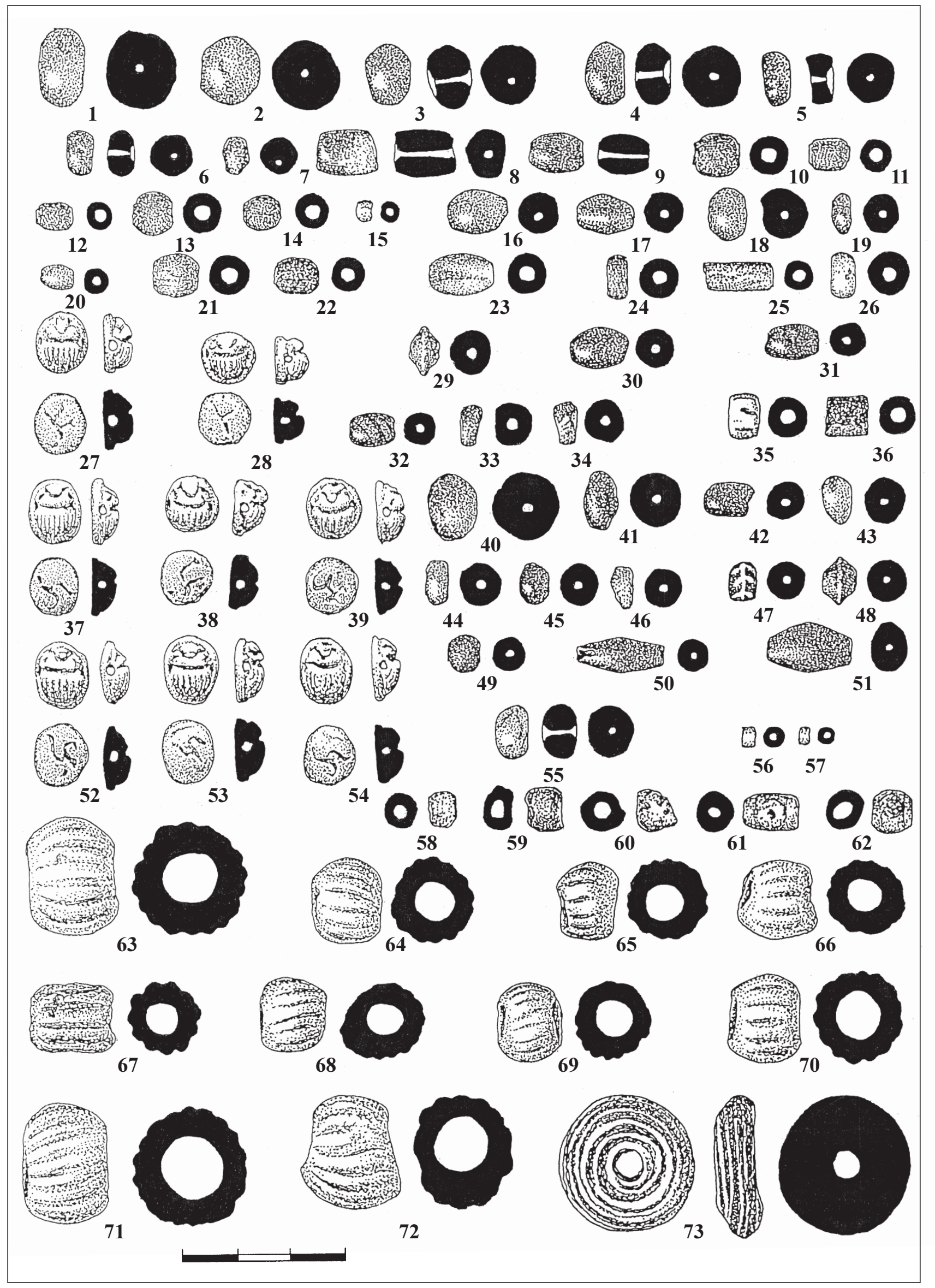

Таблица 40. Могила 35, погребение 2, бусы

1-9, 16-20, 30-34, 40-46, 55 - сердолик;10-15, 21-26, 29, 36, 47-49, 58-62, 73 - стекло; 27, 28, 35 , 37-39, 52-54, 56, 57, 63-72 - фаянс; 50, 51 - гагат 

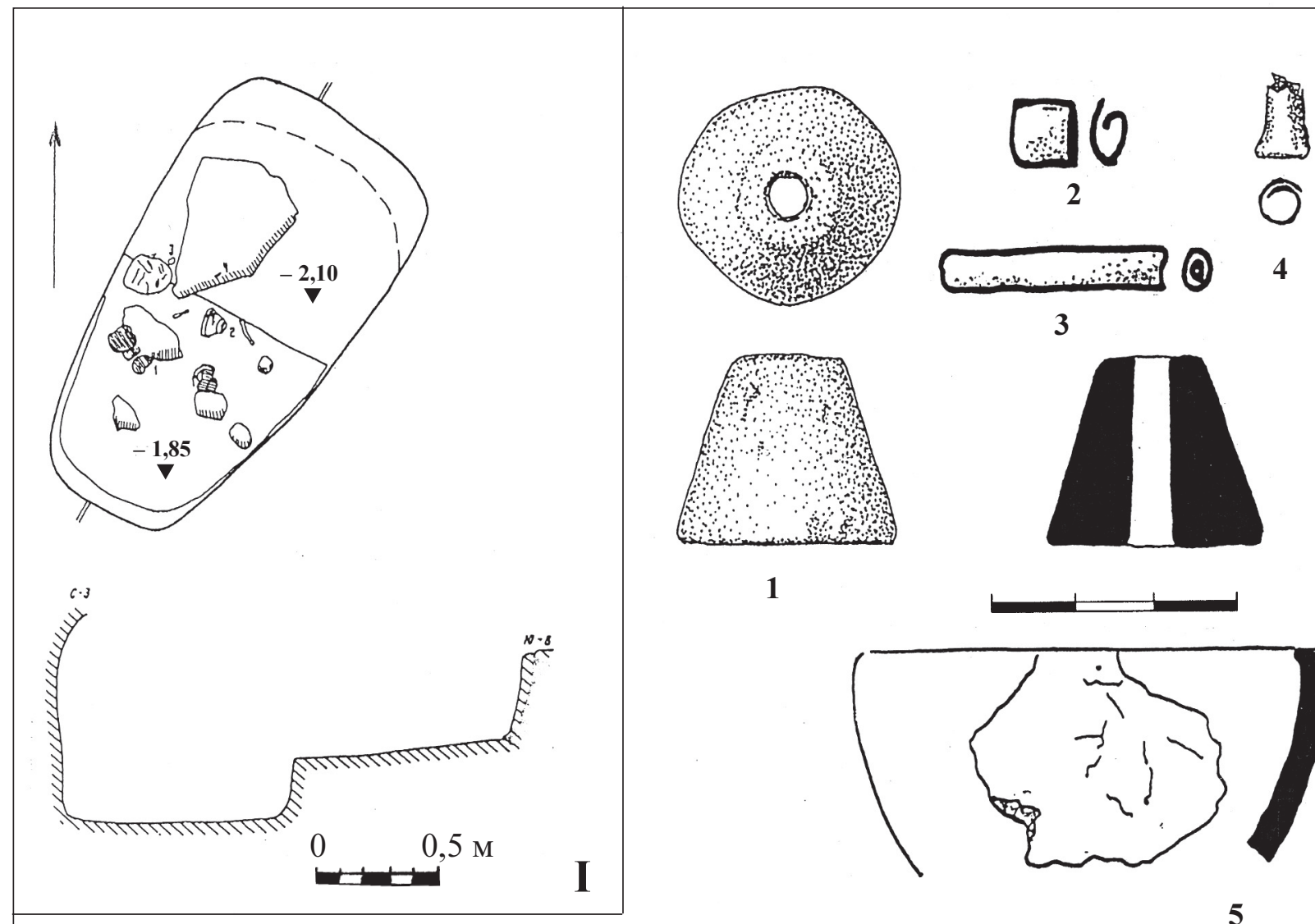

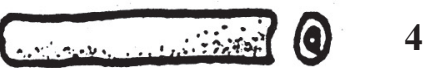

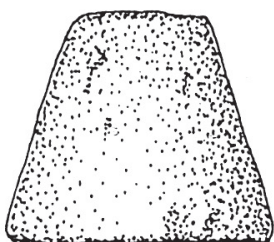

3

1
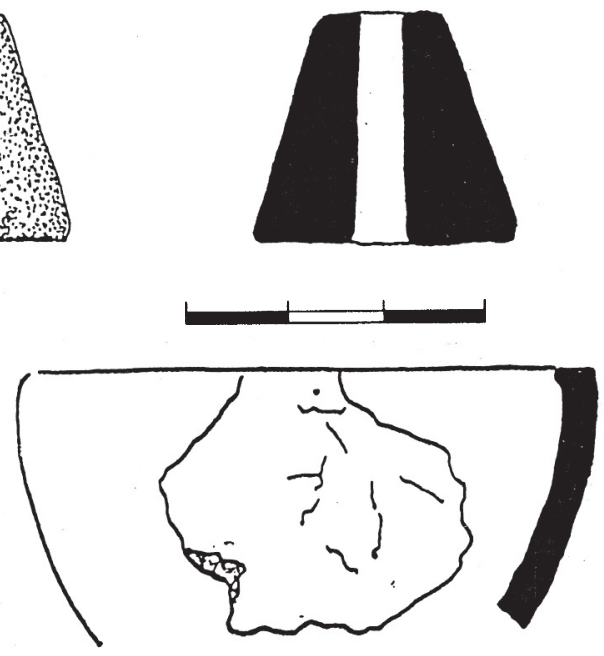

5
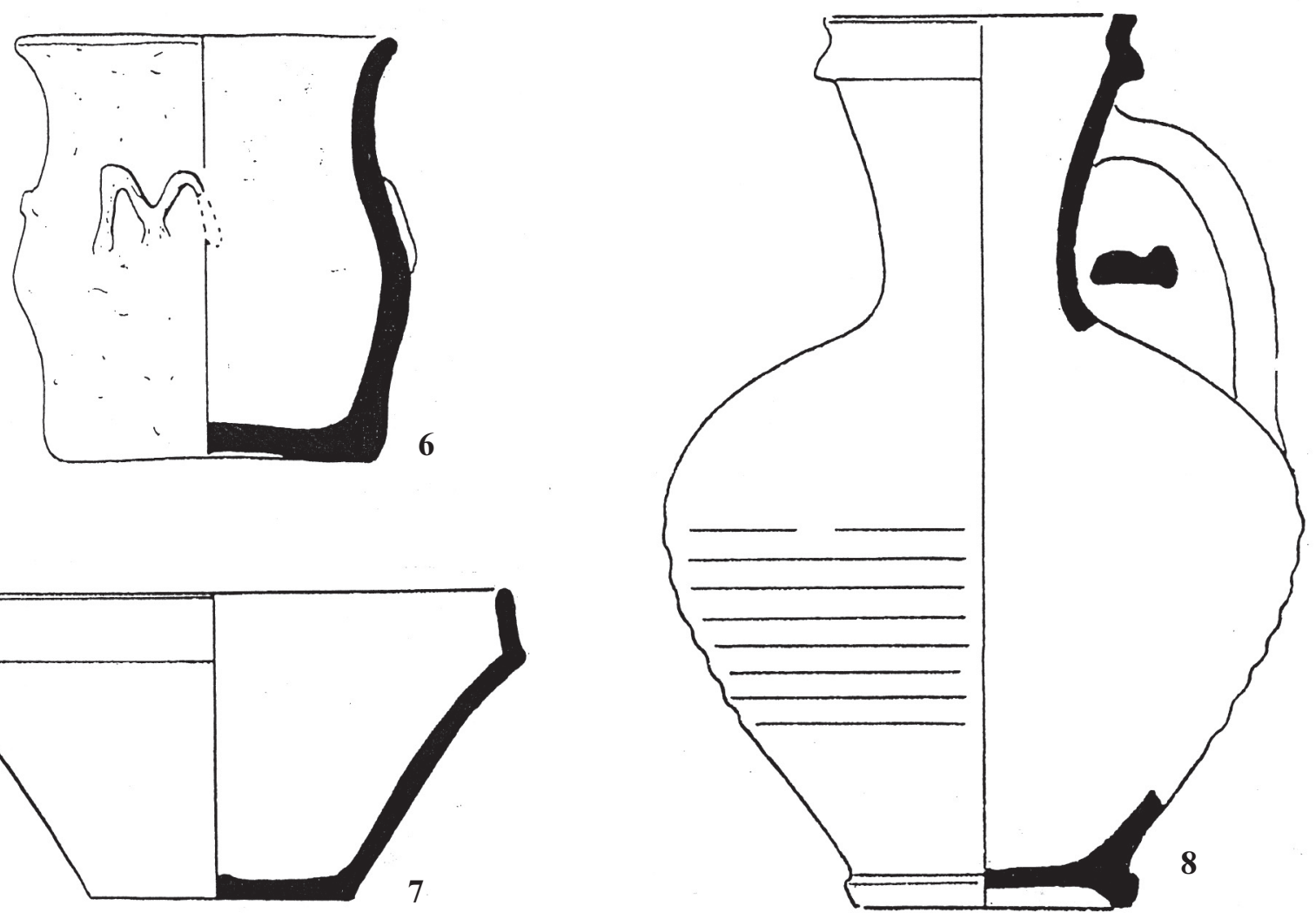

II

Таблица 41. Могила 37

I - план и разрез: 1 - кувшин, 2 - миска, 3 - пряслице, 4 - обломок лепного сосуда; II - инвентарь: 1, 5-8 - глина; 2-4 - бронза; 2-8 - рисунки Э.А. Сымоновича 


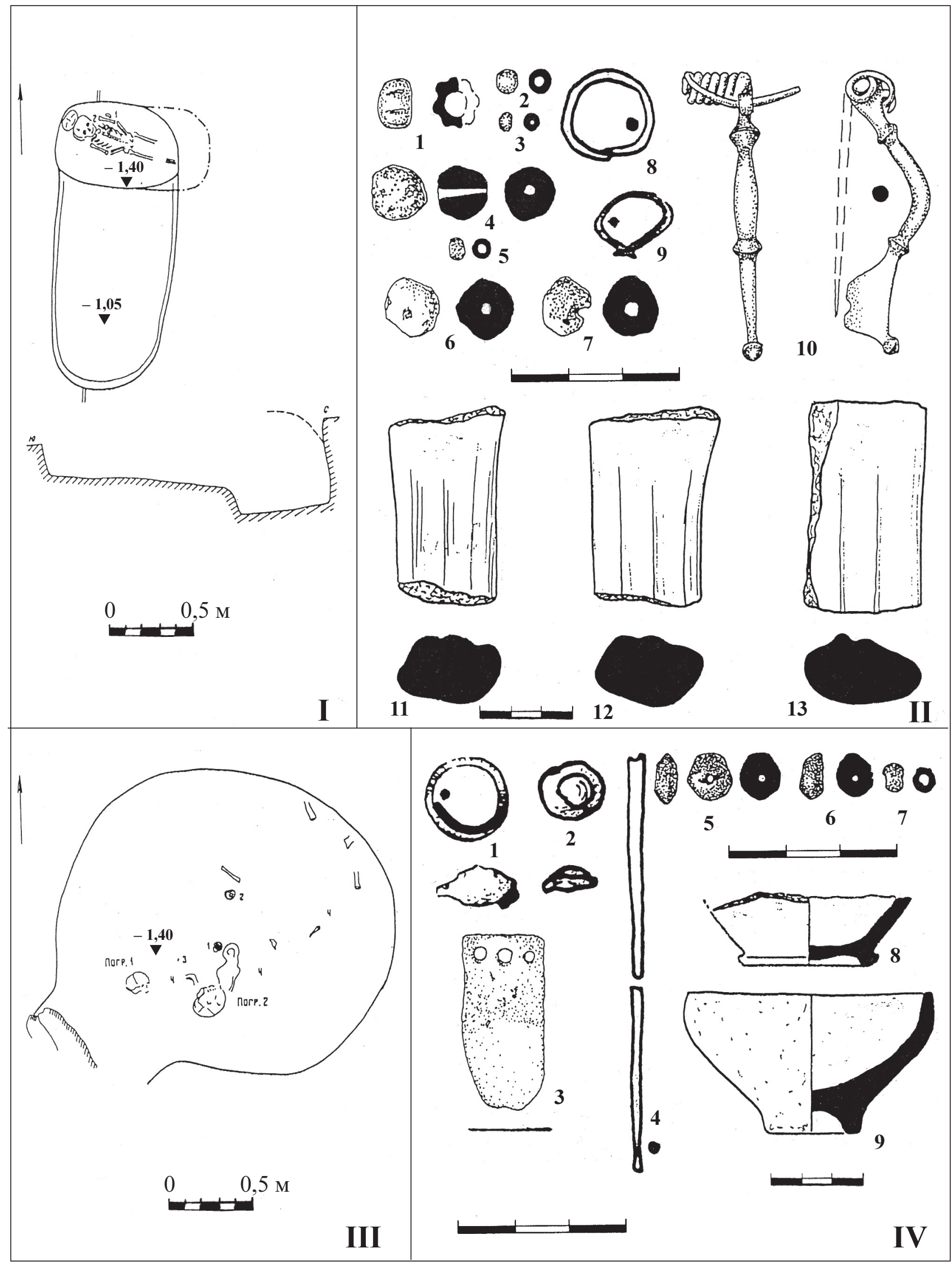

Таблица 42. Могилы 38 и 39

I - план и разрез могилы 38: 1 - астрагал барана, 2 - бусы, 3 - фибула, 4 - серьги; II - инвентарь могилы 38: 1-7 - стекло, 8-10 - бронза, 11-13 - керамика; III - план могилы 39: 1 - донце сосуда, 2 - миска, 3 - наконечник пояса, 4 - бусы; IV - инвентарь могилы 39: 1-4 - бронза; 5-6 - сердолик; 7 - стекло; 8, 9 - керамика; II, 8, 9, 11-13; IV, 1, 2, 4, 8, 9 - рисунки Э.А. Сымоновича 


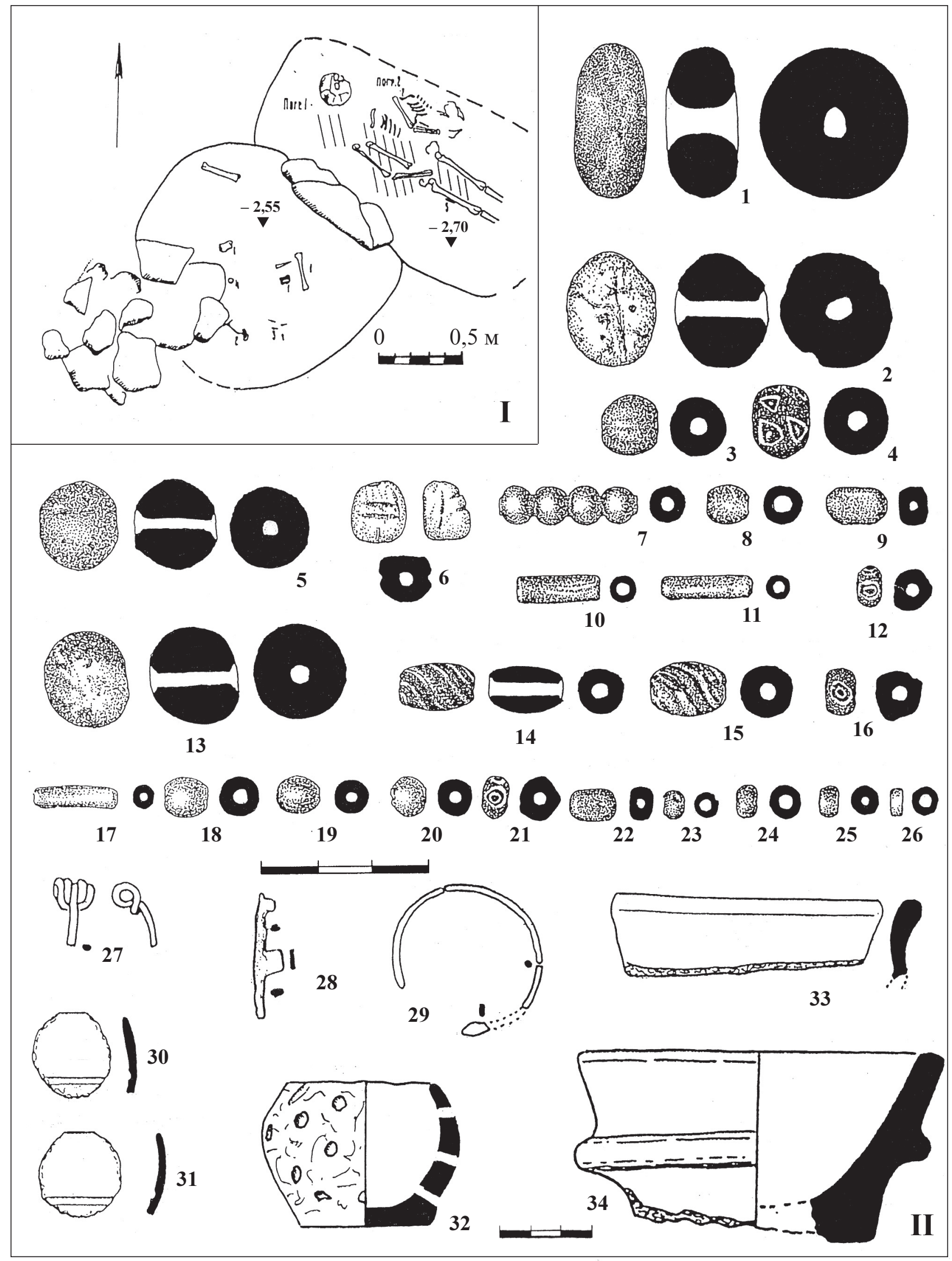

Таблица 43. Могила 40

I - план: 1 - кости лошади, 2 - удила, 3 - наконечники стрел, 4 - кольцо, 5 - нож, 6 - браслет, 7 - бусы; II - инвентарь: 1 - янтарь; 2-25, 30, 31 - стекло; 26 - фаянс; 27, 29 - бронза; 28 железо; 32-34 - керамика; 27-34 - рисунки Э.А. Сымоновича. Штриховкой показана подмазка дна зеленоватой глиной 


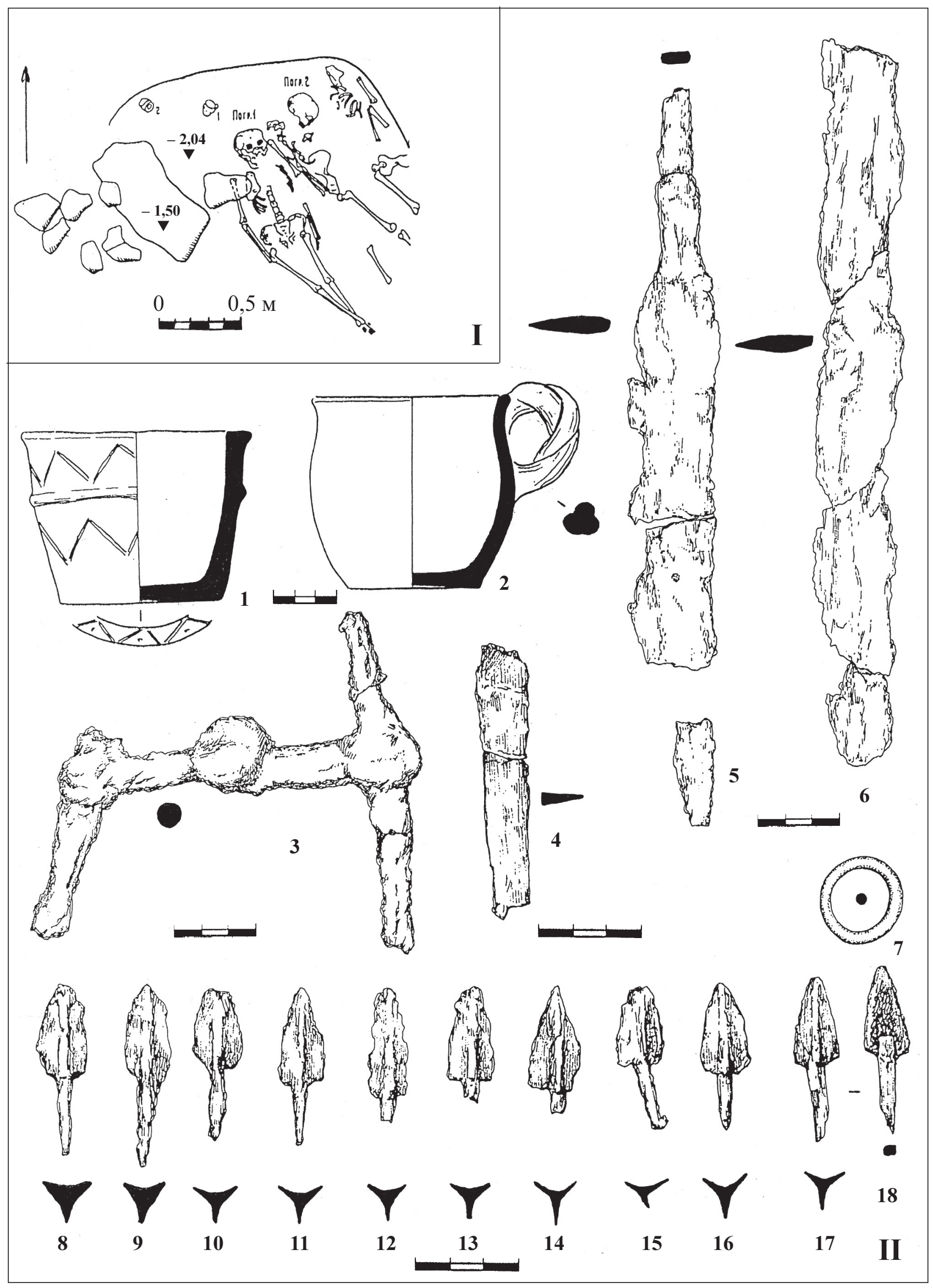

Таблица 44. Могилы 40 и 41

I - план могилы 41: 1, 2 - сосуды; 3 - железный предмет; II - инвентарь: 1-2 - могила 41; 3 18 - могила 40; 1, 2 - керамика; 3-6, 8-18 - железо; 7 - бронза; 1, 2 - рисунки Э.А. Сымоновича 


\section{СОДЕРЖАНИЕ}

Введение ............................ 3

Раскопки 1976 г. ....................... 6

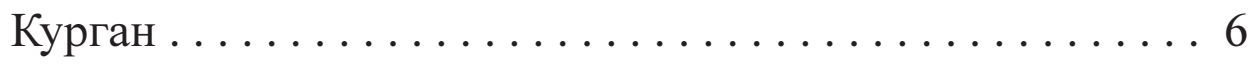

Шурф 2 , траншеи 1 и $2 \ldots \ldots \ldots \ldots$

Раскопки 1977 г. ........................... 15

Описание могил (раскоп I, шурфы 3-6) ........... 15

Описание ям на раскопе I . . . . . . . . . . . . . . 35

Заключение .......................... 36

Литература .......................... 37

Список сокращений . . . . . . . . . . . . . . 38

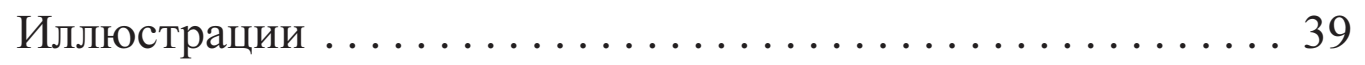


Научное издание

Гей Ольга Александровна, Сымонович Эраст Алексеевич

\title{
Позднескифский могильник Красный Маяк (раскопки 1976-77 гг.)
}

\author{
Корректор Н.В. Бельченко \\ Художник А.В. Журавлев \\ Подписано в печать 27.06.2019. Формат 60 х 84 1/8 \\ Усл.печ.л. 9,8. Уч.-изд.л. 8,5. Тираж 100 экз. \\ Зак. № 471 \\ Институт археологии РАН \\ 117292 Москва, ул. Дм. Ульянова, 19 \\ Отпечатано в филиале АО «ТОТ» «Кимрская типография» \\ 171510 Тверская область, г. Кимры, ул. Володарского, д. 11
}

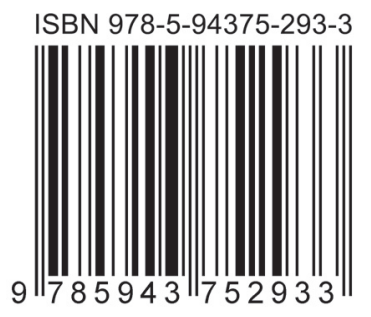

